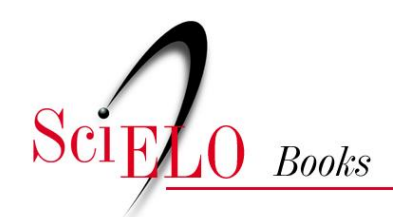

\title{
Seduepb
}

\section{Antonio Carlos Nóbrega em acordes e textos armoriais}

\author{
Luís Adriano Mendes Costa
}

\section{SciELO Books / SciELO Livros / SciELO Libros}

COSTA, LAM. Antonio Carlos Nóbrega em acordes e textos armoriais [online]. Campina Grande: EDUEPB, 2011. 196 p. ISBN 978-85-7879-186-5. Available from SciELO Books <http://books.scielo.org>.

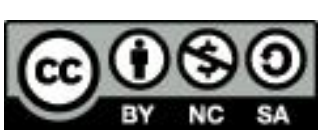

All the contents of this work, except where otherwise noted, is licensed under a Creative Commons Attribution-Non Commercial-ShareAlike 3.0 Unported.

Todo o conteúdo deste trabalho, exceto quando houver ressalva, é publicado sob a licença Creative Commons Atribuição Uso Não Comercial - Partilha nos Mesmos Termos 3.0 Não adaptada.

Todo el contenido de esta obra, excepto donde se indique lo contrario, está bajo licencia de la licencia Creative Commons Reconocimento-NoComercial-CompartirIgual 3.0 Unported. 


\section{Universidade Estadual da Paraíba}

Profa. Marlene Alves Sousa Luna

Reitora

Prof. Aldo Bezerra Maciel

Vice-Reitor

Q eduepb

\section{Editora da Universidade Estadual da Paraíba}

\section{Diretor}

Cidoval Morais de Sousa

Coordenação de Editoração

Arão de Azevedo Souza

\section{Conselho Editorial}

Célia Marques Teles - UFBA

Dilma Maria Brito Melo Trovão - UEPB

Djane de Fátima Oliveira - UEPB

Gesinaldo Ataíde Cândido - UFCG

Joseilda de Sousa Diniz - UEPB

Joviana Quintes Avanci - FIOCRUZ

Marcionila Fernandes - UEPB

Rosilda Alves Bezerra - UEPB

Waleska Silveira Lira - UEPB

\section{Editoração Eletrônica}

Jefferson Ricardo Lima Araujo Nunes

Leonardo Ramos Araujo

\section{Capa}

Arão de Azevedo Souza

\section{Ilustração da Capa}

Dantas Suassuna

Comercialização e Divulgação

Júlio Cézar Gonçalves Porto

Zoraide Barbosa de Oliveira Pereira

\section{Revisão Linguística}

Elizete Amaral de Medeiros

\section{Normalização Técnica}

Heliane Maria Idalino da Silva 
Luís Adriano Mendes Costa

\section{Antonio Carlos Nóbrega em acordes e textos Armoriais}

\section{Q eduepb}

Campina Grande-PB

2011 
Copyright $\odot 2011$ EDUEPB

A reprodução não-autorizada desta publicação, por qualquer meio, seja total ou parcial, constitui violação da Lei n 9.610/98.

A EDUEPB segue o acordo ortográfico da Língua Portuguesa de 1990, em vigor no Brasil, desde 2009.

Depósito legal na Biblioteca Nacional, conforme decreto $\mathrm{n}^{\circ} 1.825$, de 20 de dezembro de 1907. FICHA CATALOGRÁFICA ELABORADA PELA BIBLIOTECA CENTRAL - UEPB

306

C837a

Costa, Luís Adriano Mendes.

Antonio Carlos Nóbrega em acordes e textos armoriais./ Luís Adriano Mendes Costa. - Campina Grande: EDUEPB, 2011. $204 \mathrm{p}$.

\section{ISBN - 978-85-7879-087-5}

1. Cultura Popular. 2. Cultura Erudita Nordestina. 3. Movimento ArmorialMúsica. 4. Arte Memorial. I. Título. II. Nóbrega, Antonio Carlos.

21. ed. CDD

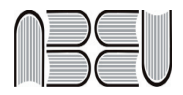

Editora filiada a ABEU

\section{EDITORA DA UNIVERSIDADE ESTADUAL DA PARAÍBA}

Rua Baraúnas, 351 - Bairro Universitário - Campina Grande-PB - CEP 58429-500 Fone/Fax: (83) 3315-3381 - http://eduepb.uepb.edu.br - email: eduepb@uepb.edu.br 
A Arte Armorial-Popular Brasileira está na rua, à disposição dos inimigos para os ataques e dos amigos para os incentivos e elogios.

Ariano Suassuna 

Ao longo desses últimos trinta anos, aprendi loas, toadas e cantigas de cirandeiros, aboiadores e cantadeiras; aprendi choros, música de Banda Cabaçal e ponteados de violeiros, pifeiros e chorões; passos, gingados e mugangas de sambadores, dançarinos e brincantes. Esses cantos, toques e danças são as pedras do meu Céu e as estrelas do meu Chão. Com eles soletro, penso, e esperanço meu sonho humano. Através deles aprendi a amar o meu país e o seu povo. Eles são o meu Lunário Perpétuo.

Antonio Carlos Nóbrega 

Madeira do Rosarinho vem à cidade sua fama mostrar, e traz com seu pessoal seu estandarte tão original. Não vem pra fazer barulho, vem só dizer, e com satisfação: 'queiram ou não queiram os juízes, o nosso bloco é de fato o campeão!'

E se aqui estamos, cantando esta canção, viemos defender a nossa tradição, e dizer bem alto que a injustiça dói, nós somos madeira de lei que cupim não rói.

Capiba 



\section{Sumário}

Lista de Figuras, 13

Prefácio, 15

Apresentação, 19

Introdução, 25

\section{Capítulo 1}

Movimento Armorial: do erudito ao popular, 31

Cultura e diversidade: Cultura erudita

e Cultura popular, 33

"Pinte bem a sua aldeia que você será universal", 44

Arte e Oralidade, 51

\section{Capítulo 2}

Os caminhos que se encontram em torno do Armorial, 65

Ariano Suassuna e o Movimento Armorial, 67

Armorial: $o$ adjetivo que se transformou em substantivo, 73 
Experimental, Romançal e a atual fase

do movimento armorial, 77

A Música Armorial, 81

Antonio Carlos Nóbrega e o Movimento Armorial, 86

Projetos e os princípios armoriais, 89

Nóbrega e seus trabalhos recitais, 92

Críticas ao Movimento Armorial, 95

\section{Capítulo 3}

\section{Acordes e textos armoriais, 105}

Acordes Armoriais: uma análise instrumental, 107

O erudito e o popular no $1^{\circ}$ Movimento do Concerto

para Dois Violinos em Ré menor, 111

Textos Armoriais: as letras falam por si, 117

As imagens como palavras: um outro texto, 156

\section{Considerações finais, 169}

Reconhecendo-se no Armorial, 171

\section{Referências, 176}

\section{Apêndices, 183}

Posfácio, 191 


\section{Lista de Figuras}

Figura 1 - Imagem da encarnação da Besta Brusacã, 127

Figura 2 - Capa do disco Na Pancada do Ganzá, 154

Figura 3 - Capa do disco Madeira que cupim não rói, 156

Figura 4 - Capa do disco Pernambuco falando para o mundo, 157

Figura 5 - Capa do disco O Marco do Meio-Dia, 159

Figura 6 - Capa do disco Lunário Perpétuo , 160 



\section{Prefácio}

\section{Braulio Tavares}

Tomei conhecimento da existência do Movimento Armorial aos 21 anos de idade, quando morava em Belo Horizonte, e meu pai me mandava páginas e recortes dos jornais de Recife dando conta das atividades do Movimento. De volta a Campina Grande em 1972, vi Ariano Suassuna dar a Aula Magna aos estudantes da Universidade Federal da Paraíba, no Teatro Municipal, e foi então que ouvi pela primeira vez (pois já se tratava das famosas aulas-espetáculo) a música do Quinteto Armorial.

Aquela música me bateu profundamente, até mesmo porque eu, como grande parte dos jovens universitários daquele período oscilava musicalmente entre o rock internacional (que para mim era sinônimo de Bob Dylan, Beatles, Rolling Stones, Jimi Hendrix) e a Música Popular Brasileira, que àquela altura já encampava a MPB dita tradicional de Chico Buarque, Baden Powell, Edu Lobo, etc., e o pós-Tropicalismo, ou que nome queiram dar à música produzida então por Caetano Veloso, Gilberto Gil, Tom Zé, Os Mutantes, etc.

A música Armorial transformou essa oscilação num ziguezague, introduzindo um novo pólo de interesse para os meus ouvidos meio duros, pois não sei nada de música, toco violão de ouvido, e tudo que sei nesse departamento é por intuição comparativa. A sonoridade armorial me seduzia acima de tudo pela sua aspereza e fanhosidade, por aquela inexatidão de notas 
que não guardavam a limpidez auto-consciente de uma nota de piano. Não, eram notas tentando o tempo inteiro se fixar em si mesmas, como a chama de uma vela tentando ficar parada durante uma ventania.

E ainda assim essas sonoridades vinham organizadas em estruturas surpreendentemente complexas. O marimbau tocado por Fernando Barbosa tinha a mesma plangência agressiva dos marimbaus dos músicos de rua, mas já aqui a serviço de outros padrões de organização. Essa convivência nunca fácil entre o popular rústico e o erudito tradicional abriu uma perspectiva nova para mim, que antes tendia a ver os dois como as extremidades opostas de uma escala qualquer.

Durante alguns anos convivi com os músicos do Quinteto, que haviam se transferido para Campina Grande; menos com Antonio Nóbrega, que por alguma razão manteve residência em Recife, e que viria no futuro a ser meu parceiro de canções e de peças teatrais, meu interlocutor em intermináveis discussões sobre Brasil, cultura e arte, e meu mestre na difícil arte de ser artista.

Este trabalho de Luís Adriano reconstitui a criação do Movimento, por Ariano Suassuna, e concentra sua análise na obra discográfica de Nóbrega. Os dois primeiros capítulos situam bem a múltipla encruzilhada onde o Movimento Armorial fincou seu castelo, num momento de radicalização e de síntese precária entre oposições do tipo popular/erudito, rural/urbano, tradicional/moderno, artesanal/industrial, rústico/tecnológico, etc.

A música espontânea (como prefiro chamá-la) e a música erudita são bairros contíguos de uma mesma cidade. Vistos à distância, um deles é só casario, o outro é só palácios; mas basta a gente chegar mais perto para ver o labirinto de avenidas, ruas e vielas que envolve os dois na mesma teia de trocas lucrativas, empréstimos compulsórios e furtos cheios de boas intenções. 
O Armorial nasceu dentro do âmbito universitário, um fato raro entre os nossos grandes movimentos de música popular. Seus princípios foram traçados nesse espírito, e seus eventos fundadores se deram nesse âmbito. Ele se alastrou e, principalmente através da atividade incansável de Ariano Suassuna, continua exercendo uma atividade permanente de criação e crítica cultural. O trabalho de Antonio Nóbrega surgiu no contexto do movimento, mas após seu desligamento do Quinteto Armorial e sua transferência para São Paulo, no início da década de 1980, foi se expandindo em direções inesperadas. Um exemplo disso é o fato do Nóbrega violinista ter se tornado também o Nóbrega dançarino.

A análise de Luís Adriano reconstitui a criação do Movimento, a inusitada riqueza de suas propostas estéticas, as polêmicas que cercaram suas atividades nos primeiros anos; e em seguida se detém na carreira solo de Antonio Nóbrega como cantor. Fica bem delineado o percurso múltiplo do "multiartista", que se desdobra em compositor, letrista, cantor, dançarino, instrumentista variado, diretor e autor. Fiel à natureza plural do movimento que o projetou, Nóbrega atua, direta ou indiretamente, no campo da música, da poética, da dança, das artes plásticas, do teatro, da mímica, do circo. Embora a análise de Luís Adriano se concentre nos aspectos propriamente musicais do seu trabalho, estes demais aspectos estão contemplados no modo como ele enfoca os arranjos musicais, a performance vocal e cênica, os elementos visuais dos shows e dos CDs.

Luís Adriano demonstra que o trabalho de Antonio Nóbrega é o mais consistente dos que se sucederam ao movimento deflagrado por Ariano Suassuna no Recife, no começo dos anos 1970. Embora os demais integrantes da primeira formação do Quinteto Armorial (Antonio "Zoca" Madureira, Fernando "Marimbau" Barbosa, Fernando "Pintassilgo" Farias, Edilson Eulálio) tenham prosseguido com sucesso em suas carreiras 
musicais e/ou universitárias, Nóbrega é certamente o que obteve maior projeção nacional, devido em parte à sua decisão de se transferir para São Paulo nos anos 1980. Com isso, a estética armorial, que antes parecia circunscrita ao Recife e ao Nordeste, ganhou não apenas divulgação nacional, mas influenciou toda uma geração de jovens artistas paulistanos e cariocas, que ao descobrirem "Tonheta" descobriram também o movimento que lhe deu origem.

O Movimento Armorial se prolonga assim, no tempo, através de uma série de pequenas explosões localizadas, na obra de grupos como Sagrama (PE), Quinteto da Paraíba (PB), Gesta (RJ) e numerosos outros. Nenhuma dessas explosões tem a capacidade de varrer o país inteiro de ponta a ponta e de se tornar "a moda do momento", porque a natureza do movimento é justamente o contrário disso; mas elas fazem frutificar elementos da estética armorial na criação de um público jovem e artistas jovens que assimilam e redistribuem os princípios do movimento. 


\section{Apresentação}

O nome armorial foi apresentado ao público, pela primeira vez, no lançamento oficial do Movimento, em 18 de outubro de 1970, na igreja barroca de São Pedro dos Clérigos, bairro de São José, em Recife. Através do texto Arte Armorial, Ariano Suassuna explicava a escolha do termo para nomear aquele que foi e continua sendo um marco na cultura brasileira e, principalmente, na cultura nordestina.

A palavra armorial, em nosso dicionário, como esclarecia Suassuna, está ligada a heráldica. Na sua visão, a heráldica, no Brasil, representa uma arte eminentemente popular, existente desde os ferros de marcar boi do Sertão nordestino, até os estandartes, as agremiações carnavalescas, as bandeiras e escudos dos clubes de futebol.

Aliás, esse foi apenas um dos motivos que justificou a escolha da palavra. Uma outra razão dizia respeito a plasticidade do nome, ou seja, a beleza da própria palavra. Questionado sobre o que motivou a escolha do nome armorial, em entrevista concedida, em 1971, ao jornal gaúcho Correio do Povo, Suassuna juntava aos dois motivos, descritos anteriormente, uma terceira justificativa, que seria justamente a própria curiosidade despertada nas pessoas ao ouvirem a palavra.

Tendo como objetivo lutar contra o processo de descaracterização e vulgarização da nossa cultura, o Armorial foi um ponto de encontro para uma série de artistas que encontraram nele as bases críticas, estabelecendo a cultura popular como possuidora da expressão mais autêntica da cultura brasileira 
e colocando a Região Nordeste como espaço que manteve, ao longo dos tempos, características singulares, definidoras da cultura brasileira.

A descaracterização e vulgarização que minava a cultura nacional, a que Suassuna referia-se como "crise exterminadora”, não era algo recente, e atingia diversos países da América Latina, cada vez mais submetidos às influências externas. Basta verificarmos o que dizia um manual lançado por uma agência de publicidade dos Estados Unidos nos anos 40, durante a permanência da atriz Carmem Miranda em Hollywood:

Exótica-excitante. Vem aí uma bomba de calor. Carmem Miranda: pimenta e tempero. Bombardeio favorito da América. O tempero da vida, a irresistível estrela tórrida. Ou ainda: A técnica de Carmem Miranda para vender uma canção é tão modulada que faz a pele arrepiar pela excitação gerada pela sua presença, o brilho de seus olhos e a sinuosa qualidade que ela injeta na sua dança casual. (ORTIZ, 1994, p. 204).

Eis um exemplo de como a imagem brasileira era evidenciada pela mídia. Um Brasil, ou melhor, um Brazyl sintetizado na imagem de Carmem Miranda, na verdade, um produto a ser vendido junto ao público norte-americano.

Toda preocupação de Suassuna em valorizar a arte brasileira erudita, baseada na raiz popular da nossa cultura, veio dar "vida", entre outros importantes projetos, ao Quinteto Armorial. Com isso, pretendia-se uma reeducação também dos nossos músicos através de instrumentos de conhecimento popular. Para utilizar as palavras do pesquisador e crítico de música José Ramos Tinhorão, o Movimento, através do Quinteto 
Armorial, conseguiu realizar a integração e a singularidade sugeridas por Suassuna, ao fundir o universal e o regional, o popular e o erudito.

Membro do antigo Quinteto Armorial e propagador do Movimento desde a sua criação por Ariano Suassuna, Antonio Carlos Nóbrega constitui-se como um dos principais representantes da Arte Armorial na atualidade. Na obra Antonio Carlos Nóbrega em acordes e textos armoriais, o artista passa a ser o protagonista dos enfoques armoriais que se tornam evidentes no seu trabalho, desde o seu teatro, passando pela dança, até suas músicas e letras - ponto crucial neste estudo.

Um fator importante e de destaque na presente publicação diz respeito ao fato dos estudos em torno do Movimento Armorial terem sido, basicamente, quase que exclusivos da literatura, com enfoques centrados nas questões literárias. Nesse sentido, buscamos aprofundar um outro tipo de abordagem, um estudo interdisciplinar da literatura com a música, uma das atividades mais fecundas que evoluiu e fez crescer o Movimento; além de tratar de um dos seus maiores seguidores, Antonio Carlos Nóbrega, que ainda não ocupa um espaço devido nas bibliografias sobre o assunto.

Fica evidente a atualidade da obra. Faz-se importante ressaltar que, ao longo da sua história, os momentos mais fecundos do Movimento Armorial coincidiram com a participação de Ariano Suassuna na esfera política. Foi assim, em 1969, quando assumiu a direção do Departamento de Extensão Cultural da Universidade Federal de Pernambuco (DEC), dando início ao que iria ser mais tarde o Movimento Armorial. Já entre os anos de 1975 e 1978, ao assumir o cargo de secretário de Educação e Cultura do Recife (na gestão do prefeito Antônio Farias), criou o Balé Armorial do Nordeste (origem do atual Balé Popular do Recife). Mais tarde, entre os anos de 1995 e 1998, foi nomeado secretário de 
Cultura do Estado de Pernambuco, pelo então governador Miguel Arraes. Nomeado secretário do executivo de Cultura do Estado de Pernambuco pela segunda vez em 2007, o escritor deixou claro que iria adotar uma política voltada para os ideais armoriais. Basta lembrar que justamente nesse ano de 2007, o escritor escreveu mais um capítulo na música armorial, ao reativar a “Camerata Armorial”, grupo criado no ano de 1996. Já em 2011, Ariano Suassuna dá continuidade ao seu trabalho em prol da cultura de Pernambuco ao integrar a equipe do Governo do Estado, assumindo o papel de secretário-chefe da Assessoria Especial do governador Eduardo Campos, mantendo, mais uma vez, uma relação estreita com a esfera política.

Assim, o reino armorial mantém-se firme, cruzando o "tabuleiro pedregozo" e decifrando uma sentença já proferida, que lhe pertence. Um reino intransponível, que tem no seu povo as bases mais sólidas desse reinado, como afirma o próprio Suassuna no poema de sua autoria Martelo D'O Marco do Meio-Dia, em parceria com o artista Antonio Carlos Nóbrega:
A Bandeira do Sol estrala ao vento
e soa a minha voz de Cantador, num protesto do Sonho contra a Dor, a pobreza do povo e o sofrimento.
Nas estrelas do Canto, o pensamento ergue um Marco que é só anunciado. Nossa sorte de Povo injustiçado é vencida por nós ao som da luta, e, no meio do palco, o que se escuta é o sol da justiça do Sonhado. 


\begin{abstract}
Ao final desta Dança bela e forte sou eu o Cantador, dono da Casa, e, com versos de sangue, fogo e brasa, forjo o Marco e celebro a minha sorte. Na viola, eu vou batendo a Morte e assumindo a coroa de Guerreiro. Ao cantar meu país, sou o Lanceiro, olho o sangue ferido do meu povo e sonho, ao meio-dia, um Canto novo, levantando este Marco brasileiro.
\end{abstract}

Na descrição detalhada do poema, vemos um mundo que envolve sangue, fogo, brasa, brilho, sonhos, justiças, crenças, lutas e glórias de um reino pertencente a seu povo, que apesar de "injustiçado", não se entrega e encontra na justiça sua força maior. Por fim, Ariano Suassuna é o cantador "dono da casa", criador do reino, seja na sua produção intelectual, seja na sua vida enquanto produtor cultural ou, ainda, o reino da "armorialidade" presente na reunião das diversas áreas artísticas com um mesmo propósito. Dessa forma, ele assume a "coroa do Guerreiro" e ao cantar seu país, torna-se um "Lanceiro", olha o "sangue ferido" do seu povo, sonhando ao meio-dia, no horário que o sol está a pino, às claras, um novo cantar ao levantar o Reino Armorial, o "Marco brasileiro".

Reunidas essas ideias, pretendemos aqui, portanto, contribuir para com um importante capítulo da história da cultura brasileira, como deve ser visto o Armorial, além de evidenciar o trabalho do músico Antonio Carlos Nóbrega, personagem importante na história do Movimento e na sua continuidade. Todos os elementos complementam-se e trazem à tona uma perspectiva atual acerca do Movimento Armorial. 



\section{Introdução}

O início dos anos 70, passados seis anos do golpe militar, foi marcado por um período de tensão que se instaurava sob a inflexível atuação da censura e da repressão. Nesse período, falar em cultura entre os poderes repressores era considerado, no mínimo, suspeito, tendo em vista a politização que orientava os grupos de cultura popular.

Em Pernambuco, a cidade do Recife, um dos polos culturais mais atuantes do país, representava um dos principais lugares onde se falava em cultura, especificamente a popular, graças a grupos de artistas e intelectuais que se reuniam com o intuito de dar expressão a "formas autênticas" da cultura brasileira.

Um desses grupos, denominado Armorial, fundado e organizado pelo escritor paraibano Ariano Suassuna, tinha como objetivo a realização de uma arte erudita, partindo das raízes populares da cultura brasileira. Toda preocupação de Suassuna em valorizar a arte brasileira erudita, baseada na raiz popular da nossa cultura, veio dar "vida", entre outros importantes projetos, ao Quinteto Armorial. Com isso, pretendia-se uma reeducação dos nossos músicos através de instrumentos de conhecimento popular, como o berimbau de lata, a viola, a rabeca, o pífano e o violão.

O presente trabalho estuda o Movimento Armorial tomando como base a obra de Antonio Carlos Nóbrega, membro do antigo Quinteto Armorial e propagador do Movimento desde a sua criação por Ariano Suassuna. Dessa forma, enfocamos traços armoriais que se tornam evidentes no trabalho do músico, desde o seu teatro, passando pela dança, até suas músicas e letras - ponto crucial neste estudo, e que projetam, inclusive, seu trabalho junto à mídia. 
Ao longo do tempo, foi estabelecida uma discussão em torno do Armorial, enquanto uma arte direcionada para intelectuais. Diante disso, partimos da seguinte indagação: De que forma o artista Antonio Carlos Nóbrega, um dos principais representantes da arte armorial na atualidade, tendo, inclusive, uma visibilidade relativa junto à mídia, tem conseguido tornar esta arte mais assimilável a um maior público? Observamos, portanto, até que ponto o artista tem conseguido torná-la mais acessível aos diversos públicos que, a exemplo do que dizem algumas críticas feitas ao Movimento, não se reconhecem no Armorial. Buscando entender essas questões, partimos do princípio de que Antonio Carlos Nóbrega, em seus espetáculos, consegue acabar com a distinção de público, de forma que, tanto o público mais erudito, quanto o mais popular se reconhecem no Armorial. Isso seria possível, talvez, pela questão da memória coletiva presente na arte armorial.

Nessa perspectiva, o presente trabalho teve como ponto de partida estudar a representatividade de elementos dessa arte nos trabalhos recitais de Antonio Carlos Nóbrega, refletindo sobre o seu papel em torná-la mais acessível a um maior público, sendo reconhecida, não somente por uma parcela mais erudita, como também pelos segmentos mais populares. Analisamos, também, o papel exercido pelo artista na valorização e representação da cultura popular nordestina. 0 estudo se caracteriza também como uma contribuição para a ampliação do acervo e das pesquisas sobre o Movimento Armorial, através da música, atividade essa de maior repercussão nacional do Movimento, ainda em carência no universo das pesquisas científicas. Perpassando esses pontos, buscamos, enfim, possibilitar uma leitura diferenciada acerca da obra de Antonio Carlos Nóbrega, que desponta como um dos trabalhos mais expressivos no cenário artístico brasileiro contemporâneo. 
Explicar a função do Movimento Armorial, através da obra de Antonio Carlos Nóbrega, representa não apenas reconhecer a herança artística deixada pelo Movimento, como também, a sua importância face à valorização, à busca por uma arte singular, uma arte que reflete a cultura de um povo, a sua identidade.

Outro aspecto que se faz importante ressaltar é a desinformação e desconhecimento da população, inclusive, da comunidade acadêmica, acerca de um movimento tão importante para a cultura nacional como foi o Movimento Armorial. $\mathrm{Na}$ verdade, constata-se a existência de uma pesquisa bastante vasta no que diz respeito ao Movimento. Nos últimos anos, são inúmeros os trabalhos que tratam do tema. Não parecem ainda satisfatórios, porém, os estudos que abordam a música armorial e um dos maiores seguidores do Movimento, Antonio Carlos Nóbrega, que ainda não ocupa um espaço devido nas bibliografias sobre o assunto.

Além disso, um outro fator não menos importante e que merece atenção se refere ao fato dos estudos em torno do Movimento Armorial terem sido, basicamente, quase que exclusivos da literatura, com enfoques centrados nas questões literárias. Nesse sentido, buscamos aprofundar um outro tipo de abordagem, um estudo interdisciplinar da literatura com a música, uma das atividades mais fecundas que evoluiu e fez crescer o movimento, a partir de um olhar cultural.

Para fazer o estudo da obra de Antonio Carlos Nóbrega, foram utilizados os cinco primeiros discos de sua carreira: $\mathrm{Na}$ Pancada do Ganzá (1996), Madeira que cupim não rói (Na Pancada do Ganzá II) (1997), Pernambuco Falando Para o Mundo (1998), O Marco do Meio-Dia (2000) e o Lunário Perpétuo (2002). Mais recentemente, o artista lançou outros dois trabalhos em homenagem ao centenário do frevo, os dois volumes do trabalho Nove de Frevereiro, 
projeto iniciado em 2004 por Nóbrega com o objetivo de gravar uma pequena coletânea de frevos instrumentais e cantados, apresentando o ritmo pernambucano em configurações mais tradicionais e em reelaborações instrumentais mais ousadas e diversificadas. Mesmo assim, para a realização do presente estudo, detivemo-nos nos cinco primeiros discos do artista, citados anteriormente, uma vez que esses trabalhos encerram uma produção discursiva que remete às propostas preconizadas pelo Movimento Armorial.

Inicialmente, foi feita uma análise para identificar a essência da Arte Armorial nos trabalhos recitais de Antonio Carlos Nóbrega, sob a forma de elementos que representam alguns traços da cultura popular e erudita, inseridos na temática poética de suas músicas e na utilização de instrumentos. Tais elementos foram associados à problemática sociocultural, expondo a contribuição enquanto arte de resistência que valoriza a identidade de um povo e, por extensão, da cultura nordestina, enfatizando, particularmente, sua capacidade em sincretizar o erudito e o popular na música regional. Para tanto, foi feito um levantamento de dois dos elementos identificadores dos estilos. Nesse caso, a temática poética e a instrumentação, apresentados através da utilização de quadros específicos, elaborados para tornar mais eficiente as análises em questão.

O presente trabalho está estruturado em três capítulos. No primeiro, intitulado "Movimento Armorial: do erudito ao popular", procuramos estabelecer as diferentes concepções entre as culturas popular e erudita, com ênfase para as elaborações armoriais acerca desses dois conceitos e seus desdobramentos, além das diversas conceituações estabelecidas por diferentes autores.

O segundo capítulo da pesquisa, intitulado "Os caminhos que se encontram em torno do Armorial", apresenta as trajetórias percorridas pelo criador do Movimento Armorial e seu 
discípulo, com destaque para as fases mais importantes do Movimento e os principais momentos da vida artística desses dois personagens em questão. Nesse capítulo, dedicamos, ainda, um significativo momento à música armorial, além de levantar pontos divergentes sobre o Movimento, elaborados através de críticas e discussões.

No terceiro e último capítulo, temos as análises e seus respectivos resultados. Para a realização da análise instrumental $^{1}$, inicialmente, foi observada a configuração instrumental presente nos discos de Antonio Carlos Nóbrega, a partir da organologia ${ }^{2}$. A partir daí, dividimos esses instrumentos em quatro categorias: metais (aerofones), cordas (cordofones), percussão (idiofones de altura indefinida); e madeiras (aerofones). Os Aerofones são instrumentos que têm seus sons extraídos através do ar; Cordofones, instrumentos cujos sons são retirados através de cordas; e Idiofones de altura indefinida, que são os instrumentos percussivos. $O$ passo seguinte foi verificar a utilização desses instrumentos dentro da execução das músicas.

Aqui trazemos, ainda, para efeito de apresentação dos procedimentos acima citados, uma análise específica entre duas versões do $1^{\underline{0}}$ Movimento do Concerto para Dois Violinos em Ré menor de Johann Sebastian Bach. A primeira delas, trazendo características eruditas, executada por uma orquestra sinfônica; e a segunda, caracterizando o popular da nossa cultura, executada pelo músico Antonio Carlos Nóbrega, adaptada para

1 Para a realização dessa parte do estudo, contamos com a colaboração do músico campinense Jorge Ribbas, com vasta experiência e atuação profissional.

2 Responsável também pelo estudo da configuração dos instrumentos, a organologia é uma área da música e desempenha um papel fundamental na categorização de instrumentos utilizados e outros aspectos que envolvem a música, como, por exemplo, a aplicação da Física. 
flauta e rabeca, também em ré menor, presente em um dos trabalhos recitais do artista, o disco Na Pancada do Ganzá. Para essa parte específica de análise, foi utilizado, também, um procedimento de análise através de um metrônomo para verificar a diferença de elaboração no conjunto da obra.

No que se refere à análise temática, utilizamos as letras das músicas dos seus cinco primeiros trabalhos recitais, quando foi possível identificar traços da cultura popular e erudita, que apontam para a presença marcante do Armorial na obra de Nóbrega. Nesse ponto do trabalho, realizamos, ainda, uma leitura cursiva das associações de imagens e palavras que estão nas capas dos discos do artista, tendo em vista o princípio Armorial de aproximar palavras e imagens. Todos os elementos complementam-se e, reunidos, trazem à tona uma perspectiva atual acerca do Movimento Armorial, à luz do trabalho de Antonio Carlos Nóbrega. 
Capítulo 1

Movimento Armorial: do erudito ao popular 



\section{Cultura e diversidade: Cultura erudita e Cultura popular}

A oposição entre cultura popular e cultura erudita está presente durante os diversos estágios culturais. Assim, a história cultural sempre foi marcada por essa polarização, ou seja, o erudito considerado por muitos como a única forma de cultura, e o popular, classificado pela "classe aristocrática" como sendo a contramão, a não-cultura, ou ainda, a ausência completa de civilização (BIZZOCCHI, 1999, p. 74).

O próprio conceito de cultura nunca foi, nem será consenso entre os estudiosos. Na verdade, sua utilização excessiva acabou, de certa forma, trazendo uma simplicidade ao termo, o que não é tão simples quando se pretende definir limites mais definidos. Cada um à sua maneira, por uma perspectiva, traz uma conceituação diferente, desde a associação da palavra cultura ao cultivo do solo e plantas, originada no mundo latino, até quando se tornou de uso corrente na Europa, sendo aplicada às sociedades humanas, com a designação de práticas de descrição, comunicação e representação. Edward Said (1995, p. 13) aponta que, de forma quase imperceptível, "a cultura é um conceito que inclui um elemento de elevação e refinamento, o reservatório do melhor de cada sociedade, no saber e no pensamento. [...] A cultura, neste sentido, é uma fonte de identidade e, aliás, bastante combativa, como vemos em recentes 'retornos' à cultura e à tradição”. Neste sentido, a cultura está associada a diversas causas políticas e ideológicas. 
No início do século, duas concepções básicas de cultura se estabeleceram entre os estudiosos: as humanistas, seletivas na sua essência, considerando alguns segmentos das atividades humanas culturais em detrimento de outros, não-culturais; e as antropológicas, não-seletivas, que apontam para a cultura como referente à trama total da vida humana numa determinada sociedade. No entanto, cabe à antropologia moderna a responsabilidade pela maioria das teorias sobre cultura.

Teóricos como Edward Burnett Tylor, Franz Boas, Lewis Henry Morgan e Emile Durkheim, que inicialmente desenvolveram teorias sobre a cultura humana, são alguns dos que traçaram o caminho da Antropologia no Século XX. Tylor, por exemplo, tratou da cultura com ênfase ao aspecto intelectual, sendo a cultura apreendida, com padrão de conhecimento partilhado. "Cultura ou civilização, tomadas no seu amplo sentido etnográfico, é aquele todo complexo que inclui conhecimento, crença, arte, moral, lei, costume e qualquer outra capacidade e hábitos adquiridos pelo homem enquanto membro da sociedade" (SACKMANN apud MARCHIORI, 2006, p. 55).

Franz Boas, por sua vez, apontou na perspectiva de que cultura "deriva do entendimento de um processo histórico específico, demonstrando a existência de uma cultura única, que descreve sua forma, a reação dinâmica do indivíduo para com a cultura e vice-versa" (MARCHIORI, 2006, p. 55).

Uma abordagem mais contemporânea acerca da cultura que, inclusive, tem servido como referência para alguns antropólogos nos últimos anos, coube ao antropólogo americano Clifford Geertz (2001, p. 5), que definiu a cultura como sendo "um sistema de concepções expressas herdadas em formas simbólicas por meio das quais o homem comunica, perpetua e desenvolve seu conhecimento sobre atitudes para a vida". 
No seu livro A Interpretação das Culturas, Geertz defende um conceito de cultura essencialmente semiótico. Para ele, cultura não se trata de uma ciência experimental em busca de leis, mas uma ciência interpretativa, em busca do significado. Geertz não concebe cultura como sendo uma realidade "superorgânica", com forças e propósitos em si mesma; nem como um padrão bruto de acontecimentos comportamentais de uma dada comunidade identificável. Na primeira, seria o caso de uma reificação; e na última, uma redução da cultura. Assim, ele afirma que, sendo como sistemas entrelaçados de signos interpretáveis, "a cultura não é um poder, algo ao qual podem ser atribuídos casualmente os acontecimentos sociais, os comportamentos, as instituições ou os processos; ela é um contexto, algo dentro do qual eles podem ser descritos de forma inteligível - isto é, descritos com densidade" (GEERTZ, 1978, p. 24).

O conceito de cultura pode, ainda, ser entendido como um processo de desenvolvimento intelectual de um indivíduo ou de um determinado grupo, no meio social de convívio. Nesse sentido, esse processo envolve uma série de entendimentos comuns, refletidos na representação de valores, símbolos e significados entre as pessoas que, de alguma forma, dividem ou mantêm algum tipo de convívio, possibilitando a transmissão desses elementos e assim a perpetuação às novas gerações. O certo é que são várias as abordagens em torno da cultura, com diferentes correntes de pensamento. As definições trazem ideias, ideologias, pensamentos, valores, costumes, crenças, entre vários outros conteúdos de significados variáveis, de acordo com o enfoque dado.

Da mesma forma, estabelecem-se as discussões em torno da cultura popular e da cultura erudita, com pontos divergentes entre pesquisadores e estudiosos. No caso específico da cultura erudita, trata-se da chamada cultura livresca, detentora do conhecimento, associada às elites, apresentando-se no interior 
das universidades e, ignorando, portanto, as manifestações do povo. Como afirma Bosi (2001, p. 326), a cultura erudita é aquela que se desenvolve, principalmente, nas classes mais altas e em outros segmentos "mais protegidos da classe média: ela cresce com o sistema escolar". Conforme Bizzocchi (1999), a cultura erudita, tradicionalmente, pode ser entendida como aquela consumida pela elite cultural e econômica, sendo claramente um sinal de status para essa parcela minoritária da sociedade. "Ela reforça o poder opressivo da classe dirigente, e sua fetichização enfraquece o poder e silencia a maioria" (KUPER, 2002, p. 291).

0 termo cultura erudita está, então, associado às representações ideológicas e artísticas de uma parcela minoritária da sociedade de classes: as elites. E é essa parcela mínima da sociedade que estabelece e impõe as diversas regras dojogo. Utilizamos a palavra jogo para definir o conjunto de relações entre os grupos e os diferentes componentes da estrutura social.

A classe dirigente não é a consciência universal de uma sociedade, mas um grupo particular que possui interesses particulares, e que é definido pela dominação que impõe ao conjunto da sociedade. Enquanto classe dominante, a classe superior identifica a historicidade com os seus interesses, a reifica e, portanto, transforma a produção em herança, a ação inovadora em interesses adquiridos. (TOURAINE apud FUNARI, 1989, p. 14).

Ao contrário da cultura erudita, a cultura popular é vinculada ao conhecimento obtido e praticado no seio das comunidades, ou seja, junto à parcela majoritária da população, com suas práticas formadas sem um saber científico, surgidas das atividades vivenciadas pela própria população. Gabriel Garcia Márquez (apud FUNARI, 1989, p. 15) ressalta a cultura popular 
como aquela constituída "das imortais tradições da humorística do povo, hostil a todos os cânones e normas, oposta a todas as noções definitivas e petrificadas sobre o mundo: o que um homem não pode fazer, as comunidades o fazem".

Utilizando um pensamento de Canclini (1997, p. 205), o popular estaria descrito então como os incapacitados de produzir um produto digno de reconhecimento, não chegando, portanto, ao patamar de 'artista', nem a participar do mercado de bens simbólicos legitimizados, sendo assim, o popular, um mero espectador, ausente da universidade e dos museus. Quanto ao consumo, o popular estaria na última fila, no final do processo, fadado a reproduzir a ideologia dos dominadores.

Nessa perspectiva, Bizzocchi (1999) aponta a arte popular como aquela consumida pelas classes mais baixas. Ponto de vista compartilhado por Bosi, ao classificar o popular como pertencente aos "estratos mais pobres" e, em certo ponto, Canclini, ao afirmar que o "popular é nessa história o excluído: aqueles que não têm patrimônio ou não conseguem que ele seja reconhecido e conservado". Assim, "o popular costuma ser associado ao prémoderno e ao subsidiário" (CANCLINI, 1997, p. 205); e quanto à cultura erudita, essa "quer sentir um arrepio diante do selvagem" (BOSI, 2001, p. 330).

Sobre a elaboração da cultura popular, Ayala e Ayala, em Cultura Popular no Brasil (2003), afirmam que:

A cultura popular não constitui um sistema, no mesmo sentido em que se pode falar de sua existência na cultura erudita - um conjunto de produções artísticas, filosóficas científicas etc., elaboradas em diferentes momentos históricos e que têm como referência o que foi realizado anteriormente, pelo menos desde os gregos, naquele campo determinado e nos demais. [...] Assim, 
comparadas com a cultura erudita, as manifestações culturais populares são, de certa forma, dispersas, elaboradas com um maior desconhecimento de sua própria produção anterior e de outras manifestações, produzidas por integrantes dos mesmos grupos subalternos, às vezes em locais bastante próximos e com características estéticas e ideológicas semelhantes. (AYALA; AYALA, 2003, p. 66-67).

Xidieh (1976, p.3) define a cultura popular como sendo aquela “(..) criada pelo povo e apoiada numa concepção de mundo toda específica e na tradição, mas em permanente reelaboração mediante a redução ao seu contexto das contribuições da cultura 'erudita', porém mantendo sua identidade".

No caso específico da cultura do Brasil, os estudos antropológicos já faziam a distinção clara, a partir de um critério racial, entre as culturas indígena, negra, branca e mestiça. Ao longo dos anos da história brasileira, a cultura branca, proveniente dos europeus, foi associada à erudição, uma cultura letrada, estabelecendo uma diferença para com as culturas populares, elaboradas sem a necessidade de um conhecimento prévio, sendo assim, o popular associado a algo grosseiro e representaria um elemento simbólico, permitindo aos intelectuais, como afirma Ortiz (1994, p. 161), "tomarem consciência e expressarem a situação periférica da condição do país em que se encontram”.

Um outro ponto de vista sobre os elementos da cultura popular pode ser empregado a partir de uma outra visão, que não seja a mesma aplicada na maioria dos estudos sobre a cultura popular e seus respectivos contextos sociais, como apontam os estudos de Roger Bastide e seus alunos da Universidade de São Paulo (AYALA, 2003, p. 32). Bastide sugere que a cultura popular deve ser vista como parte de um contexto cultural e social mais amplo, sendo necessário que seja entendida em termos atuais e 
não apenas como elemento de sobrevivência mantido ao longo dos anos por registros, muitas vezes, localizados e isolados, sem nenhum tipo de contextualização social e histórica. Para utilizar o pensamento de Arantes, pensar a cultura popular como sinônimo de tradição é reafirmar ou sugerir

que a sua Idade de Ouro deu-se no passado. Em conseqüência disso, as sucessivas modificações por que necessariamente passaram esses objetos, concepções e práticas não podem ser compreendidas, senão como deturpadoras ou empobrecedoras. Aquilo que se considera como tendo tido vigência plena no passado só pode ser interpretado, no presente, como curiosidade. [...] essas maneiras de pensar a cultura pressupõem ou que ela seja passível de cristalização, permanecendo imutável no tempo a despeito das mudanças que ocorrem na sociedade, ou, quando muito, que ela esteja em eterno 'desaparecimento'. (ARANTES, 1990, p.17-21).

A cultura popular, nessa perspectiva, não deveria ser vista apenas como a responsável pela manutenção das tradições, desatualizada do contexto atual e sempre remetendo a um tempo que passou. É o que diz Bastide (apud AYALA, 2003), ao tratar a cultura pela perspectiva de "produção" ou, ainda, de "re-produção".

As práticas culturais só se mantêm, desaparecem ou se modificam à medida que os homens, vivendo sob certas condições econômicas e sociais, realizam ou deixam de realizar aquelas práticas. Aparecem, nos estudos de Roger Bastide, as condições de vida, os interesses, os conflitos entre os diferentes grupos sociais (durante a 
escravidão, por exemplo, os senhores de escravos, a Igreja, os homens livres brancos e negros, os escravos), relacionados com as pressões a favor ou contra a existência de certas manifestações e sua modificação. (AYALA, 2003, p. 33).

As condições econômicas e sociais, com os diferentes interesses e conflitos apontados, no estudo de Roger Bastide, são fundamentais, quando se trata da caracterização das práticas culturais, que se mantêm, desintegram ou se refazem, na medida em que são utilizadas ou deixadas de lado dentro de um contexto social.

Dessa forma, Ayala e Ayala (2003, p. 62) consideram que esse tipo de abordagem, localizando a cultura popular numa origem rural, na tradição, no passado, na "preservação pela imitação", além de impor uma visão do popular como algo anacrônico, coloca a cultura popular como produto ou "bens culturais", não levando em consideração que, assim como toda cultura, a popular só se mantém a partir da sua reelaboração permanente.

Para Suassuna, conforme diz Carlos Newton Júnior (1999), a questão da arte popular e da arte erudita é típica de culturas constituídas por povos que dominam outros. Ao longo da sua história, a arte popular, no Brasil, sobrevive pelas mãos de poucos, que insistem em resistir às influências do colonialismo cultural. E, dessa forma, ela é preservada até hoje, pela tradição de artistas populares, contra os quais se voltam "todas as imposições e os modelos uniformizantes que procuram solapar os resquícios ainda não submetidos da nossa cultura - da massificação cultural à confusão proposital que tentam fazer entre cultura popular e cultura de massa" (NEWTON JÚNIOR, 1999, p. 102). Sobre essas imposições mercadológicas, diz Sérgio Paulo Rouanet (1987, p. 20): "é o modo mais competente de liquidar a cultura popular". 
No caso do Brasil, a arte popular identifica-se com aqueles elementos do povo "mantidos, de qualquer forma, desde o século XVI, à margem da cultura oficial. São os descendentes mais escuros de ibéricos pobres, negros e índios" (SUASSUNA apud NEWTON JÚNIOR, 1999, p. 102). Conforme avalia Newton Júnior, em seguida, a arte erudita é realizada por uma outra parcela do povo, constituída pelos ibéricos portadores da então cultura oficial.

Quando Suassuna classificou o fazer artístico como sendo uma atividade elitista, não se referia ao sentido econômico do termo, mas sim à existência de uma elite popular e uma erudita. Isso porque o sistema econômico ao qual o país está submetido impossibilita o direito de muitos que poderiam vir a desenvolver seu potencial artístico: "sem dúvida qualquer contacto aturado com a arte é susceptível de acordar ou favorecer ignoradas ou latentes tendências artísticas" (COCHOFEL apud NEWTON JÚNIOR, 1999, p. 103). Aliás, conforme esclarece o próprio Newton Júnior (1999, p. 103), a arte popular "não é inferior ou superior à erudita; são categorias diferentes, cada uma com seu valor próprio".

A criação do Movimento Armorial, junto ao trabalho de artistas populares, além de defender essas características "autenticamente" brasileiras, pretende desmistificar o conceito de que a arte erudita seja de melhor qualidade, ou ainda, superior à arte popular. 0 que existe é uma visão equivocada acerca de elementos totalmente diferentes. Não seria a arte erudita a "arte superior" e, nem tampouco, a arte popular a "arte inferior". o fazer artístico seria uma atividade para elites, sejam elas, popular ou erudita, uma vez que a arte não é algo democrático, com oportunidades iguais para todos. Para Suassuna, existiria uma elite popular, formada por artistas populares, a exemplo de J. Borges, na xilogravura; Leandro Gomes de Barros, 
no cordel; e uma elite erudita, formada por outra parcela de artistas, preocupados com a verdadeira essência da cultura brasileira, a exemplo dos armorialistas.

Seguindo esse pensamento, não se trata aqui de querer ser popular ou erudito. Assim como diz Newton Júnior (1999, p. 103104), "um determinado artista que tenha formação erudita não poderá, mesmo que queira, fazer arte popular. 0 que ele pode fazer é ligar-se de alguma maneira ao popular, realizando uma arte erudita brasileira, calcada nas raízes populares da nossa cultura". Referindo-se a essas características inerentes ao artista popular, Ariano Suassuna (apud DIDIER, 2000, p. 71) comenta que "a despreocupação com a técnica e o desrespeito pela questão formal tornam mais livre esse artista. E o aproveitamento pelo erudito das formas populares é a única maneira de se formar uma arte nacional, por causa de sua pureza". Para ele, "a grande força da arte popular é que ela expressa aquilo que o povo vê e o que o povo sente [...] o povo se expressa como quer e como acha que deve se expressar" (LINS; VICTOR, 2007, p. 82-83). Sobre essa questão, Hermilo Borba Filho (apud DIDIER, 2000, p. 68) avalia que a cultura popular pode ser relacionada com a espontaneidade ingênua e tem como maior diferença com o erudito, a "inigualável" capacidade de improvisação e interação com o público. A autenticidade é, assim, associada à espontaneidade do povo, formalizando uma diferença entre as características próprias da cultura popular e reflexivas da cultura erudita.

Nesse caso, Suassuna defendia a essência poética do romanceiro através dos "folhetos" como uma expressão fundamental da cultura brasileira, podendo servir de bandeira à estética armorial. Dessa forma, "a poesia pode dar origem à literatura e ao teatro, a gravura pode dar origem à talha e à escultura e, por último, os folhetos são comumente cantados ao som de violas e rabecas" (SUASSUNA apud DIDIER, 2000, p. 42). 
Além de se apresentar como uma marca expressiva da cultura popular brasileira, os "folhetos" subsistiram à margem das influências do colonialismo cultural, sendo o cerne para os postulados básicos do Movimento Armorial.

A Arte Armorial Brasileira é aquela que tem como traço comum principal a ligação com o espírito mágico dos 'folhetos' do Romanceiro Popular do Nordeste (Literatura de Cordel), com a Música de viola, rabeca ou pífano que acompanha seus 'cantares', e com a Xilogravura que ilustra suas capas, assim como com o espírito e a forma das Artes e espetáculos populares com esse mesmo Romanceiro relacionados. (SUASSUNA, 1974, p.7).

Sendo ponto fundamental na criação do movimento, o cordel passou a ser uma das fontes para o trabalho do escritor, envolvendo a literatura, através das histórias contadas em versos; a música, pelo viés das toadas; e as artes plásticas, através das xilogravuras, presentes nas capas dos folhetos. O criador do Movimento Armorial elege o cordel como sendo a forma verdadeira e original de expressão do povo brasileiro, como podemos ver nessa entrevista de Suassuna concedida ao professor Ronaldo Salgado (1995) e alguns estudantes de jornalismo da Universidade Federal do Ceará:

A grande importância do folheto, no meu entender, é que o folheto é o único espaço em que o povo brasileiro se expressou sem influências e sem deformações que lhe viessem de cima, de fora. Aqui ele não imitou a França, não imitou a Inglaterra nem os Estados Unidos. O povo brasileiro aqui se expressou como ele é. Então essa é a grande lição do folheto em feira. (SALGADO, 1995). 
A busca por essas "formas autênticas" da cultura brasileira idealizadas por Suassuna seria determinante no que se pretendia em relação à definição do caráter nacional, diante do processo de descaracterização e alienação por que passava não apenas a cultura brasileira, como, também, a de outros países da América Latina, cada vez mais submetidos às influências externas.

\section{"Pinte bem a sua aldeia que você será universal"}

Ao citar a frase do escritor russo Tolstói, Suassuna demonstrava seu posicionamento em relação às influências estrangeiras. Para o idealizador do Movimento Armorial, seria no passado, na volta às suas origens, que a cultura brasileira estaria identificada. o pensamento armorial estabelece as expressões populares do Nordeste como as bases originárias da cultura nacional.

Nesse sentido, era na tradição, ou seja, na cultura popular que poderia se originar a identidade cultural da nação. "Primordialmente vinculada ao passado, à 'pureza' e à identidade nacional, a cultura popular, nessa concepção, é possuidora de essência e linearidade" (DIDIER, 2000, p. 35). Era assim que essa identidade estaria mais preservada e, consequentemente, menos exposta às imposições externas.

Nas culturas tradicionais, o passado é honrado e os símbolos valorizados porque contêm e perpetuam a experiência de gerações. A tradição é um modo de integrar a monitoração da ação com a organização tempo-espacial da comunidade. Ela é uma maneira de lidar com o tempo e o espaço, que insere qualquer atividade ou experiência particular dentro da continuidade do passado, presente e futuro, sendo estes por sua vez estruturados por práticas sociais 
recorrentes. [...] A tradição não só resiste à mudança como pertence a um contexto no qual há, separados, poucos marcadores temporais e espaciais em cujos termos a mudança pode ter alguma forma significativa. (GIDDENS, 1991, p. 44).

É nesse contexto que Ariano Suassuna aponta para a cultura popular como possuidora da expressão mais autêntica da cultura brasileira e coloca a Região Nordeste como espaço que manteve, ao longo dos tempos, características singulares, definidoras da cultura brasileira. Autores como Celso de Magalhães, José de Alencar e Sílvio Romero concordam com esse ponto de vista e associam essa questão "à noção de que a cultura popular é rude, rústica, ingênua, enfim, algo que se opõe àquilo que está relacionado com o progresso: a 'civilização"' (AYALA, 2003, p. 14).

Assim, é nos tocadores de rabeca e violeiros, cantadores, cordelistas, que a cultura popular é considerada detentora da permanência dessas representações culturais, sendo possuidora de uma essência enraizada nas origens, definidora do caráter nacional. É no passado que o armorial define os traços dessa identidade cultural. E seria nessa volta ao passado, que o Nordeste, mais especificamente, o Sertão, estaria identificado como uma região rica, ampla e original, seja na preservação de costumes e traços antigos de um povo, ou ainda, na representação simbólica de resistência.

Referindo-se à música sertaneja, Suassuna diria que vinculava 'à música indígena (meio asiática), à música ibero-árabe (ou ibero-mourisca) e à gregoriana, tudo contribuindo para ligar a música sertaneja ao espírito primitivo e classicizante, pré-clássico, digamos assim, dos motetos medievais ou da música renascentista menos cortesã'. 
A concepção de fusão das etnias culturais (negro, índio, europeu), expressando as tradições genuínas, pode ser considerada como o lastro das recriações armoriais. (DIDIER, 2000, p. 56-57).

Esse pensamento é compartilhado pelo escritor Antônio Callado e o diretor de teatro Luís Mendonça. O primeiro, ao se referir à obra A Pena e a Lei, de Ariano Suassuna, considerava que a peça envolvia o telespectador "num ambiente autêntico de infância, a infância talvez do próprio País, que é muito nordestino em sua essência" (CALLADO apud DIDIER, 2000, p. 72-73). Ou seja, o Nordeste acaba prevalecendo em relação às demais, estabelecendo-se um vínculo entre a região, a cultura popular e um passado que abriga a identidade nacional do país. Já o diretor de teatro Luís Mendonça (apud DIDIER, 2000, p. 73), nos anos 70, considerou que "se quisermos fazer um teatro realmente nacional, não podemos deixar de nos voltar para o bumba-meu-boi, as incelenças, o pastoril, o demônio, o cordel. Aliás, está mais do que na hora de se buscar a origem de nossa arte cênica e esta origem (...) está cada vez mais, apenas no Nordeste".

Para Hall (2005, p. 59), uma cultura nacional nunca foi um simples ponto de união entre os diferentes membros, seja em termos de classe, gênero ou raça. Ele considera a cultura nacional uma estrutura de poder cultural. Esse ponto de vista é compartilhado por Ortiz (1994, p. 8) que, em Cultura Brasileira e Identidade Nacional, utiliza a expressão "relações de poder" para representar a estrutura da cultura brasileira. Ponto de vista compartilhado por Ayala e Ayala (2003):

A diferença de posições dos diferentes grupos sociais na estrutura de classes implica a existência de concepções de mundo que se contrapõem. A cultura popular tanto veicula os pontos de vista e interesses das 
classes subalternas, numa perspectiva de crítica à dominação, mais ou menos consciente, quanto internaliza os pontos de vista e interesses das classes dominantes, legitimando a desigualdade existente. [...] Tendo sempre presente que a cultura popular e os que a produzem não estão isolados dos demais segmentos da sociedade, a atenção volta-se para a vinculação das questões acima mencionadas com a estrutura de classes, a cultura e a ideologia dominantes. [...] Hoje, a contextualização implica situar a cultura popular enquanto processo dinâmico e atual no interior de uma sociedade dividida em classes com interesses antagônicos. (AYALA; AYALA, 2003, p. 51-52).

Essas "relações de poder", conforme argumentam Antonio Gramsci e Raymond Williams (apud WALTER, 2005, p. 5), podem ser entendidas como um processo dinâmico de entendimentos entre grupos e discursos distintos, tornando esse processo como uma "negociação entre discursos oficiais e dissidentes". Walter (2005) conclui que ir de encontro a essa "agitação cultural", considerando a existência de uma espécie de homogeneidade total da cultura, identidade, território e idioma, reflete o desconhecimento de elementos vitais que os constituem, desfaz e refaz numa contínua apropriação e reapropriação.

Na verdade, por trás de toda essa questão, está um processo conhecido como "globalização", que se refere "àqueles processos, atuantes numa escala global, que atravessam fronteiras nacionais, integrando e conectando comunidades e organizações em novas combinações de espaço-tempo, tornando o mundo, em realidade e em experiência, mais interconectado" (McGREW apud HALL, 2005, p. 67). 
Walter $(2005$, p. 3) vai mais além, ao lembrar o pensamento de Arjun Appadurai, no sentido de que os crescentes fluxos presentes nessa rede global de relações "minam noções fixas de nação e do sujeito autossuficiente", sendo necessária uma maior reflexão sobre essas formas de relacionamento cultural e identitário. E acrescenta:

A globalização e mundialização tardias são caracterizadas por relações conjuntivas e disjuntivas entre os vários fluxos globais e as formas e práticas globais mais estáveis criando uma encruzilhada onde os elementos culturais se entrelaçam, se chocam, se sobrepõem, se apropriam mutuamente dentro de uma estrutura hierárquica e de um processo de dominação e subordinação e desta forma aceleram vários tipos de problemas e fricções: subsistência, justiça, governo, episteme e identidade, entre outros. (WALTER, 2005, p. 3).

Em toda sociedade, esse processo se faz presente e atua numa relação entre maior/menor, de dominação/resistência. Nessa nova ordem global, os "periféricos" se ressentem de um controle maior de suas próprias necessidades, que vão se dissolvendo frente às influências externas. É o que diz Moacir dos Anjos, no seu livro Local/global: arte em trânsito, ao afirmar:

Esse receio da 'McDonaldização' do mundo não considera, contudo, a complexidade dos mecanismos de reação e adaptação das culturas não-hegemônicas ao impulso de anulação das diferenças que a globalização engendra, promovendo formas novas e específicas de pertencimento ao local e criando, simultaneamente, articulações inéditas com o fluxo global de informações. (ANJOS, 2005, p. 11). 
São muitos os teóricos que argumentam que as identidades culturais estão sendo fragmentadas devido a esses processos em escalas globais. Como afirma Hall, essas identificações globais podem deslocar e, até mesmo, apagar as identidades nacionais. "À medida em que as culturas nacionais tornamse mais expostas a influências externas, é difícil conservar as identidades culturais intactas ou impedir que elas se tornem enfraquecidas através do bombardeamento e da infiltração cultural" (HALL, 2005, p. 74).

Dessa forma, é importante destacar o pensamento de Walter (1999, p. 77), ao discutir a mudança no conceito de cultura, passando de determinadas comunidades nacional-cultural com significados partilhados de um lugar fechado em relação a outras, para uma crescente hibridação cultural. "É uma maneira de pensar a cultura não como entidade fechada e determinada por um etos e uma cosmovisão tradicionalmente estáticos, mas como espaço transcultural de influências mútuas entre diversas culturas".

Essa relação entre diferentes culturas nunca se dá de uma maneira igual. Na verdade, assim como diz Walter, ao apontar uma das possibilidades do processo de globalização:

[...] 'o movimento precursor de uma transformação de estruturas sociais e culturais' no sentido de nos conscientizar do fato de que a chamada 'aldeia global' sem fronteiras e limites é simplesmente a mais recente fachada (ideológica) para distorcer/velar a existência real das fronteiras e dos limites internos e externos que continuam a dividir o mundo em oprimidos e opressores, margens e centros. (WALTER, 1999, p. 99-100). 
No entanto, alguns autores nordestinos apontam que é na cultura popular que vai se encontrar uma representação simbólica de resistência, de originalidade e uma identidade cultural. Tal aspecto está presente no pensamento armorial, como resistência a esse processo de achatamento das culturas locais por fatores externos, como alertava Suassuna, ao afirmar:

Não sei se o pessoal do Sul já se apercebeu suficientemente da importância, para o Brasil, do movimento artístico que está se realizando atualmente no Nordeste. Os escritores e artistas nordestinos não se preocupam com a 'crise' que, segundo os alarmistas, vai exterminando a cultura brasileira. E, enquanto os do Sul, parece que apavorados por essa notícia criada artificialmente, vão entrando pelos becossem-saída do desespero, do vanguardismo, do som universal, da arte cosmopolita, os nordestinos vão levando adiante seu trabalho criador de modo cada vez mais atuante, mais profundo, mais ligado às raízes da cultura brasileira. (SUASSUNA apud DIDIER, 2000, p. 51-52).

A "crise" exterminadora da cultura brasileira a que Suassuna se referia dizia respeito justamente ao processo de vulgarização e descaracterização da cultura nacional, o que não era algo recente. Já nos anos 40, a imagem brasileira evidenciada pela mídia era a de um Brasil, ou melhor, um Brazyl, sintetizado na imagem de Carmem Miranda, na verdade, um produto a ser vendido junto ao público norte-americano. Produto esse que atendia as seguintes características, 
conforme um manual lançado por uma agência de publicidade dos Estados Unidos, durante a permanência da atriz brasileira em Hollywood:

Exótica-excitante. Vem aí uma bomba de calor. Carmem Miranda: pimenta e tempero. Bombardeio favorito da América. O tempero da vida, a irresistível estrela tórrida. Ou ainda: A técnica de Carmem Miranda para vender uma canção é tão modulada que faz a pele arrepiar pela excitação gerada pela sua presença, o brilho de seus olhos e a sinuosa qualidade que ela injeta na sua dança casual. (ORTIZ, 1994, p. 204).

Faz-se necessário verificar, ainda, um outro aspecto dentro desse processo de integração dos países, costumes e culturas em escala mundial vistos anteriormente. Se esse processo de homogeneização cultural pode acarretar a perda dessas identidades locais e nacionais, tradicionais, com o surgimento de novas identidades, "híbridas", por assim dizer, por outro lado, pode levá-las a esse trabalho de resistência, de reforço dessas culturas frente aos modelos uniformizantes.

\section{Arte e Oralidade}

Relações, como, hegemônico/subalterno, culto/popular se acentuam ainda mais quando se trata de outro aspecto, o moderno/tradicional, com o moderno vislumbrando novos horizontes, avanços das mais diferentes naturezas e o tradicional vinculado ao atraso das classes populares, à condição de subalterno, cristalizado e pronto para ser revisitado na condição de vitrine tradicional, uma vitrine sem novidades, que não 
produz nada de novo durante o passar dos anos, mas que pode ser revisitada a todo o momento, muito mais para lamento do tempo passado do que para apontar novas perspectivas, servindo como ponto de sustentação para os 'hegemônicos'. "Se a cultura popular se moderniza, como de fato ocorre, isso é para os grupos hegemônicos uma confirmação de que seu tradicionalismo não tem saída; para os defensores das causas populares, torna-se outra evidência da forma como a dominação os impede de ser eles mesmos" (CANCLINI, 1997, p. 206).

Nesse ponto, Canclini (1997, p. 277) adota um posicionamento bastante razoável, considerando que esse conflito entre tradição e modernidade não implica num

[...] sufocamento exercido pelos modernizadores sobre os tradicionalistas, nem como a resistência direta e constante de setores populares empenhados em fazer valer suas tradições. A interação é mais sinuosa e sutil: os movimentos populares também estão interessados em modernizar-se e os setores hegemônicos em manter o tradicional, ou parte dele, como referente histórico e recurso simbólico contemporâneo. (CANCLINI, 1997, p. 277)

A estética moderna intensifica essas diferenças. Um exemplo disso é a oposição entre arte e arte popular, com a arte vinculada ao "movimento simbólico desinteressado, um conjunto de bens 'espirituais' nos quais a forma predomina sobre a função e o belo sobre o útil" (CANCLINI, 1997, p. 242), sendo a arte popular uma forma de produção utilitária, com seus objetos indissociados dos seus sentidos práticos. 
O que dizer, então, de uma matéria veiculada no Jornal da Paraíba, no dia 6 de outubro de 2006, sobre a obra "Guaraná Power" 27a Bienal de São Paulo? A obra, do grupo dinamarquês Superflex, fazia referências críticas à indústria de refrigerantes. Na oportunidade, o trabalho, que havia sido selecionado para a mostra brasileira pelo grupo de curadores, acabou não sendo aceito para ser exposto no evento, fato que rendeu duras críticas ao presidente da Bienal, Manuel Francisco Pires da Costa, pelo grupo Superflex que, em documento distribuído à imprensa, fazia a acusação de censura por parte do presidente, por não considerar a obra uma "atividade artística". Esse, por sua vez, defendia-se da acusação, afirmando que a intervenção da obra selecionada teria sido por parte do departamento jurídico da Bienal, informando que a obra não estava de acordo com as regras da legislação brasileira.

o documento escrito pelo grupo dinamarquês Superflex afirmava que a obra teria o reconhecimento internacional e que já havia sido apresentada em outros eventos daquela natureza, a exemplo da Bienal de Veneza, no ano de 2003, além de ter sido, o grupo Superflex, elogiado pelo Ministro da Cultura Gilberto Gil. Polêmicas à parte, seria essa uma atividade artística, digna de um reconhecimento dos órgãos internacionais, ligados ao fazer artístico?

No seu livro O que é arte Jorge Coli (1984) relata a iniciativa de Marcel Duchamp ao inserir um mictório numa exposição artística, no sentido de provocar uma discussão em relação à

3 O projeto Guaraná Power foi iniciado, no ano de 2003, pelos integrantes Bjornstjerne Christiansen, Jakob Fenger e Rasmus Nielsen, em parceria com fazendeiros da cidade de Manaus, no Amazonas. A proposta surgiu a partir de um estudo econômico realizado na comunidade, afetada pela redução dos preços das sementes de guaraná devido ao controle pelas indústrias de refrigerantes. 
utilização de objetos fabricados em série, porém, desviados de suas funções pelas suas instalações em museus, galerias, centros artísticos, ao que Duchamp classificava como ready-made. Dessa forma, ele apontava para a necessidade de reconhecimento por parte do público culto que para se tornar artístico, o objeto deve ser aceito pelas diversas "competências", sejam elas os críticos, museus, historiadores, entre outras.

Compreendemos então o interesse da atitude de Duchamp dentro do domínio da arte: crítica à atitude solenemente 'culta' que nossa civilização confere ao contacto com o objeto artístico; denúncia do aspecto convencional da atribuição do estatuto de arte pelos instrumentos da cultura; criação de uma antiarte. Mas, supremo poder desses instrumentos culturais, os objetivos de Duchamp, que deveriam ser apenas testemunhos de um gesto de questionamento, conservados em museu adquirem efetivamente o estatuto de arte. 0 mictório que, pela sua função receptora de excremento, evoca o lado animal, orgânico e, portanto, menos 'nobre' do homem, está nos antípodas da concepção de arte como instrumento de elevação do espírito: é antiarte por excelência. Convertido em peça de museu, assume o papel de objeto de contemplação, passa a provocar 'sentimentos' no espectador. Aliás, esta função 'artística' da antiarte não escapa ao pensamento de Duchamp - ele próprio dizia: 'são os olhadores que fazem um quadro'. Qualquer objeto aceito como arte, torna-se artístico. (COLI, 1984, p. 68). 
Uma outra forma de separação seria a de que os produtores da 'verdadeira' arte produzem isoladamente, enquanto os populares seriam produtores coletivos e anônimos; e, enquanto a arte produz obras inéditas, únicas, a arte popular seria elaborada em série, assim como a "música popular reitera estruturas idênticas em suas canções, como se lhes faltasse 'um projeto' e se limitassem 'a consumir um protótipo até o cansaço, sem nunca chegar a discuti-lo como cosmovisão e, em consequência, a defendê-lo esteticamente mediante todas as suas variáveis" (CANCLINI, 1997, p. 243).

Dentro desse processo, deve-se atentar para um aspecto importante da narrativa, elemento bastante presente na elaboração das artes populares, que diz respeito à questão da memória. Tal aspecto se estabelece numa relação até certo ponto "ingênua" entre narrador e ouvinte, como afirma Walter Benjamin.

Para o ouvinte imparcial, o importante é assegurar a possibilidade da reprodução. A memória é a mais épica de todas as faculdades. Somente uma memória abrangente permite à poesia épica apropriar-se do curso das coisas, por um lado, e resignarse, por outro lado, com o desaparecimento dessas coisas, com o poder da morte. (BENJAMIN, 1985, p. 210).

Trata-se de um elemento constitutivo da identidade social, que tem influência direta nas interpretações, atitudes, gestos e pensamentos apresentados a partir dos grupos e doutrinas a eles pertencentes, nos quais, os indivíduos estão inseridos. Coube à memória, portanto, a preservação dessas características que se mantêm por muito tempo vivas, muitas vezes, porém, no anonimato. Vejamos o que dizem os versos do poeta Manoel Florentino Duarte, no seu cordel É um pouco de tudo da Puizia 
Matuta (apud FUNARI, 1989, p. 15): “O cofre da minha memória / é grande subterrâneo / não há quem calcule os versos / que se acumulam no meu crânio / é mais do que o volume / da água do Mediterrâneo. //"

Vejamos o que diz sobre essas questões o escritor e poeta Bráulio Tavares, no seu livro Contando história em versos: poesia e romanceiro popular no Brasil:

No mundo da literatura oral, não existe 'a' versão oficial. Não existe original: tudo é cópia. Como tudo é feito na base da memória, cada versão é diferente da anterior. É raro que se encontrem duas versões exatamente iguais; mas não importa. Cada uma é tão legítima quanto as outras. Quando alguém conta uma história extraordinária numa sala de visitas, ou uma história de fadas junto à cama de uma criança, ou uma lenda folclórica diante de um auditório cheio de alunos, não está preocupado em saber se essa história está sendo contada 'exatamente como é'. Ela é aquilo que está sendo naquele momento. Sua forma é a que aquele narrador lhe dá naquele instante; ela existe apenas para as pessoas que estavam ali, naquele momento. (TAVARES, 2005, p. 106).

É o que afirma certamente Alfredo Bosi (2001, p.35), ao dizer que "a memória extrai de uma história espiritual mais ou menos remota um sem-número de motivos e imagens, mas, ao fazê-lo, são os seus conflitos do aqui-e-agora que a levam a dar uma boa forma ao legado aberto e polivalente do culto e da cultura". 
O Auto da Compadecida, marco na história do teatro brasileiro, de Ariano Suassuna, é um exemplo dos mais conhecidos. A peça se caracteriza como uma obra popular e tem nos seus personagens uma mitologia própria, baseada em leituras de possíveis arquétipos brasileiros. É o caso do padeiro e da sua mulher, do bispo, do padre, do major Antônio Moraes, do cangaceiro, da Nossa Senhora, do Chicó e do João Grilo.

Na peça, as hilariantes situações são temas multisseculares fornecidos ao autor pelos folhetos. O primeiro ato se baseia em 0 enterro do cachorro, fragmento do folheto 0 dinheiro, de Leandro Gomes de Barros, que conta o episódio do cachorro morto, cujo dono destina uma quantia em dinheiro para que o enterro do animal seja feito em latim, o que dá origem a uma série de trapalhadas na classe clerical. Essa história do testamento do cachorro se baseia num conto popular de origem moura que, segundo o próprio Suassuna, teria chegado pela Península Ibérica por intermédio dos árabes do norte da África. O segundo ato é inspirado na História do cavalo que defecava dinheiro, que mostra o episódio do gato que "descome" moedas e o da falsa ressurreição dos personagens ao som do instrumento mágico, depois da chegada do cangaço, tendo à frente Severino de Aracaju, chefe do bando. E o terceiro e último ato, que narra o julgamento dos personagens no Céu e a intercessão piedosa de Nossa Senhora, a "Compadecida", correspondem ao folheto 0 castigo da soberba. Os textos são anônimos, presentes na tradição popular nordestina, e procuram recuperar e reproduzir elementos narrativos da comédia medieval e renascentista da Europa. Dessa forma, a história do Gato que descome dinheiro, origina-se no Cavalo que defeca dinheiro, que, por sua vez, já seria originado em clássicos da literatura universal, como A Galinha dos Ovos de Ouro ou João e o Pé-de-Feijão.

O mesmo processo de apropriação e renovação acontece com o personagem João Grilo. Ele é claramente uma espécie de encarnação do personagem Pedro Malazarte, talvez entendido 
como o herói espertalhão mais conhecido e que, na Península Ibérica, tinha o nome de Pedro Urdemalas. Assim como esses, o Lazarillo de Tormes, famoso por guiar cegos, sobrevivendo a duras custas em meio à miséria e violência; o Cancão de Fogo, dos folhetos de Leandro Gomes de Barros; o "Sabido Sem Estudo", de Manoel Camilo dos Santos; voltando a personagens da Commedia dell'Arte européia, como o Arlequim; chegando até o personagem Tonheta de Antonio Carlos Nóbrega, e o Trupizupe, o Raio da Silibrina, de Bráulio Tavares; que trazem consigo características semelhantes.

O Pedro Quengo e o João Grilo do Romanceiro, o Benedito e Negro Preguiçoso do Mamulengo, o Mateus e o Bastião do Bumba-meu-boi são todos variantes do mesmo pícaro que herdamos da Literatura ibérica de origem popular e que, lá também, tanto se parece com os graciosos do Teatro de Calderón de La Barca ou Lope de Vega. (SUASSUNA apud BITTER, 2000, p. 21).

Ou seja, um processo de apropriação que atravessou o Atlântico e que, como o próprio Suassuna afirma no que se refere à escolha do nome, estaria fazendo uma ponte entre o seu teatro e o cordel nordestino, cujo personagem já existiria no trabalho de João Martins de Athayde, intitulado Proezas de João $G$ rilo ${ }^{4}$. Todos eles, típicos heróis, conhecidos como picarescos que aprontam peças e se utilizam da sua esperteza tanto para com os ladrões e bandidos, como para as classes mais abastardas e as maiores autoridades.

4 Pesquisadores atribuem ao pernambucano João Ferreira de Lima esse cordel, surgido inicialmente em forma de folheto de oito páginas sob o título "As Palhaçadas de João Grilo", sendo ampliado, posteriormente, por João Martins de Athayde, para 32 páginas, atual forma como é apresentado. 
No seu ensaio Dialética da Malandragem, Antonio Candido (1993, p. 22) elenca algumas características dos personagens pícaros: "[...] o choque áspero com a realidade, que leva à mentira, à dissimulação, ao roubo, e constitui a maior desculpa das 'picardias'. Na origem, o pícaro é ingênuo; a brutalidade da vida é que, aos poucos, o vai tornando esperto e sem escrúpulos, quase como defesa [...] atributo adquirido por força das circunstâncias". Essas características ficam evidentes durante toda a obra Auto da Compadecida. As expressões "necessidade", "defesa", "me virar" e "abandono" são utilizadas, com frequência, quando o assunto é João Grilo. É o que acontece no terceiro ato da peça, no episódio do julgamento, quando ele, João Grilo, vai fazer sua defesa para não ir para o inferno. Ele diz: "[...] Se tivessem tido que agüentar o rojão de João Grilo, passando fome e comendo macambira na seca, garanto que tinham mais coragem." (Suassuna, 2005, p. 142). A sua destreza é tanta que, além de obter a graça de voltar a Terra para uma segunda oportunidade, ele consegue impedir a ida de outros cinco pecadores em julgamento para o inferno, arrumando cinco vagas no purgatório.

Malazarte, Canção de Fogo, João Grilo, todos herdeiros do mesmo molde, têm ancestrais conhecidos: o Bertoldo bolonhês de Giulio Cesare Croce (século XV). Como arquétipo longínquo situa-se o Marcolfo do anônimo Dialogus Salomonis et Marcolphi, texto latino do século XII, em que o turpissumus rusticus sempre leva a melhor, armado da autoridade de seus provérbios. É interessante notar que o uso dessas fórmulas fixas da expressão traduz o mesmo estado de espírito e visão de mundo que propiciam o emprego da repetição e o caráter de memorização encontrados na literatura oral. (VASSALO, 2000, p.179). 
Foi dessa maneira que tais personagens resistiram e resistem ao passar dos anos. Assim como o cordel e o Romanceiro Ibérico, as características picarescas desses personagens foram ficando, principalmente, na região Nordeste "graças a essa cultura subterrânea que nada anota e nada esquece. Pessoas que sabiam histórias e passavam-nas adiante; pessoas que sabiam ler, pegavam versões escritas dessas histórias orais e passavamnas adiante" (Tavares, 2005, p. 107).

Da mesma forma, A história de amor de Fernando e Isaura, primeira ficção em prosa de Ariano Suassuna, foi uma regionalização de um dos grandes mitos do amor no Ocidente, a lenda de Tristão e Isolda, de Béroul, que seria fonte, inclusive, direta ou indiretamente, do clássico Romeu e Julieta. É o que diz Wilson Martins (2000, p. 111), ao afirmar que a lenda difundiu-se, na Europa, a partir de 1130, através de numerosas compilações. Em 1900, Joseph Bérdier já teria feito uma adaptação moderna da mesma obra. Mais uma vez verifica-se o processo de recriação. $\mathrm{Na}$ lenda original, o rei Marco encarrega o sobrinho, Tristão, de procurar uma princesa para que ele se case. Portando um líquido mágico destinado a despertar o amor entre os futuros esposos, Tristão se descuida e deixa que Isolda, figura de beleza deslumbrante, beba por engano o filtro mágico. O resultado é o surgimento de uma paixão irresistível e proibida entre os dois personagens. Na versão de Ariano Suassuna, os personagens Fernando e Isaura também vivem um amor intenso e verdadeiro, que por não poder ser vivido em sua plenitude, caminha para um desfecho trágico. A recriação da história é verificada mais uma vez no Romance d'A Pedra do Reino e o príncipe do sangue do vai-e-volta, de autoria de Ariano Suassuna, quando dois personagens se apaixonam pelo resto de suas vidas depois de beberem de um vinho, sem saber que a bebida exerceria um papel de cupido entre eles. 
Está presente de forma bastante evidente o princípio armorial de criação a partir de obras anteriores, seja aprofundando, reafirmando ou enriquecendo. 0 Romance d'A Pedra do Reino e o príncipe do sangue do vai-e-volta, com sua releitura das inspirações e tradições ibéricas, como o Romance da Nau Catarineta, a História de Carlos Magno, a História de Roberto do Diabo; misturada com a comedia dell'arte e o circo de beira de estrada, para citar alguns poucos elementos presentes na vasta obra, é um exemplo desse trabalho de reinterpretação e elaboração dos trabalhos armoriais. A obra apresenta grandes discussões estéticas entre os personagens Quaderna, Clemente e Samuel, além de extrair histórias dos gêneros de poesia do romanceiro popular nordestino.

O próprio trabalho poético de Ariano Suassuna, iniciado com a publicação do poema Noturno, no Jornal do Commercio, no dia 7 de outubro de 1945, é fonte essencial na compreensão da estética preconizada pelo criador do Movimento Armorial. Como mostra o escritor Carlos Newton Júnior, no seu livro 0 pai, o exílio e o reino: a poesia armorial de Ariano Suassuna, a temática reino é bastante presente na obra do escritor, que recria seu passado e procura reconstruir um mundo perdido através da literatura, nesse caso, um reino construído no imaginário do autor, o reino encantado de sua infância. 0 reino primordial, desaparecido no mundo real, mas que sobrevive na sua memória, é a fazenda Acauhan-Malhada da Onça, nome de um soneto presente no seu primeiro álbum de iluminogravuras, Sonetos com Mote Alheio, lançado em 1980. Suassuna promove uma fusão dos nomes das duas fazendas que pertenceram ao seu pai e recria seu reino como se fosse um lugar único. Nesse sentido, a concepção de reino em Suassuna passa pela necessidade vital do autor em habitar um reino, que vai acompanhá-lo para toda a vida. 
Como mostra Newton Júnior, fica claro que o projeto de reino em Suassuna vai se propagando não somente na sua obra, mas também, na sua vida e atuação enquanto produtor cultural. Do reino da fazenda para Taperoá, passando pelo Sertão paraibano, para todo o Sertão nordestino, chegando até o Nordeste e, enfim, à Ilha Brasil ${ }^{5}$. Assim como nessas outras manifestações artísticas, sua poesia aponta para a tônica principal da sua produção, ao fazer uso das formas poéticas do romanceiro popular nordestino, aliado à recriação erudita de temáticas extraídas de assuntos originados daquele rico universo.

Essas obsevações chamam atenção para uma outra característica dos trabalhos armoriais que diz respeito à integração das artes, ou seja, os diversos gêneros artísticos e as obras devem estar em harmonia, complementando-se mutuamente. São diversos os casos dentro da estética armorial. O Romance d'A Pedra do Reino é um caso significativo e pode ser considerado emblemático nesse sentido, ao ser modelo de inspiração para outros artistas, a exemplo do trabalho desenvolvido pelo pintor Aluízio Braga, tendo por base A Pedra do Reino, quando ele produziu uma série de quadros; e Jarbas Maciel, ao compor uma música com mesmo título da obra maior de Suassuna, que foi gravada pela Orquestra Armorial. Um outro caso bastante evidente são os dois álbuns de iluminogravuras ${ }^{6}$ confeccionados

5 Esse foi o tema da tese de Mestrado em História que Ariano Suassuna apresentou no dia 30 de dezembro de 1976. Intitulado "A Onça Castanha e a Ilha Brasil - Uma reflexão sobre a Cultura Brasileira", o estudo apresenta importantes reflexões sobre a nossa formação cultural, servindo de fundamentação teórica para o Movimento Armorial.

6 Trabalho criado por Ariano Suassuna, que resulta da fusão da iluminura medieval com os processos modernos de gravação em papel. As iluminogravuras eram produzidas por Suassuna através de uma matriz da ilustração e do texto em manuscrito, com nanquim preto sobre papel branco. Em seguida, eram feitas cópias da matriz em uma gráfica, no 
por Ariano Suassuna na década oitenta, que também podem ser citados como exemplos dessa integração preconizada pelos trabalhos armorialistas.

Esse processo de recriação está bem evidente na música armorial, que teria seu trabalho caracterizado "pela investigação e recuperação de melodias barrocas preservadas pelo romanceiro popular, dos sons de viola, dos aboios e das rabecas dos cantadores. [...] Procurava articular elementos de um passado preservado com uma linguagem musical que nomeava de nova, autêntica e representativa da cultura brasileira" (DIDIER, 2000, p. 103). Ou seja, assim como as demais atividades artísticas elaboradas dentro da perspectiva do Movimento, a música seguia à risca a estética armorial, buscando refletir esse trabalho de recriação da autêntica cultura nordestina, formada na base popular da cultura, sem nenhuma influência exterior ${ }^{7}$. Assim, aliado à recriação erudita originada naquele rico universo, fazia-se uso de ritmos relacionados ao estilo de música nordestina, como, por exemplo, a embolada e o martelo.

processo de off-set. Cada exemplar era trabalhado manualmente, colorido a pincel com tinta guache e/ou óleo, numa prancha de papel cartão, com as dimensões $44 \mathrm{~cm} \mathrm{x} 66 \mathrm{~cm}$, contendo um soneto e as respectivas ilustrações. O primeiro álbum, intitulado Sonetos com Monte Alheio, foi lançado em 1980. A segunda coletânea de iluminogravuras foi lançada cinco anos depois e chamava-se Sonetos de Albano Cervonegro.

7 No que se refere à influência exterior, é preciso observar que para os armorialistas nem todo estrangeirismo era considerado "estranho". As influências ibéricas do passado, por exemplo, representam uma das raças formadoras da cultura brasileira, ou seja, a influência ibérica para os armoriais era, portanto, a participação moura/árabe na definição do caráter nacional, juntando-se aos negros, brancos e índios formando o ser Castanho na "Ilha Brasil". Essa concepção de fusão das raças formadoras da nossa cultura (negro, índio, branco) para formação do ser Castanho, expressando a pureza das tradições, pode ser considerada como a base das recriações armoriais. 
É nessa perspectiva que se desenvolvem os trabalhos em torno do armorial, que ao serem elaborados, reelaborados e reescritos, parecem inacabados, possibilitando outras abordagens provisórias e momentâneas, uma espécie de prática instrumental. A obra armorial constitui-se, assim, numa espécie de grande mural, com fragmentos literários, visuais, e musicalidade presentes em todos os elementos. O grande arcabouço da obra armorial seria como a gola colorida de terbrim ou veludo que faz parte da indumentária dos caboclos de lança ou lanceiros do Maracatu, com as diversas atividades artísticas representadas pelas miçangas, vidrilhos e lantejoulas, todas bordadas e constituindo parte importante na peça como um todo. 0 processo de recriação das artes armoriais passa essa ideia de circularidade, com múltiplas direções e aponta a região Nordeste como portadora das bases necessárias, a partir da preservação e utilização de elementos dessa tradição. Seja na música, literatura, teatro, artes plásticas, tapeçaria, pintura, escultura, esse é o grande ganho da Arte Armorial, que ao longo de suas fases conseguiu reunir artistas de campos diferentes com um mesmo propósito. 
Capítulo 2

Os caminhos que se encontram em torno do armorial 



\section{Ariano Suassuna e o Movimento Armorial}

Para uma melhor compreensão acerca do surgimento do Movimento Armorial, faz-se necessário uma volta ao ingresso do criador do Movimento no cenário cultural pernambucano, iniciado na Faculdade de Direito do Recife, em 1946. É lá que Suassuna encontra um campo propício para desenvolver seu potencial criador, passando a conviver mais diretamente com pessoas que estavam envolvidas com várias formas artísticas, como a pintura, a literatura e o teatro:

no meu tempo as opções eram três: Engenharia, Direito e Medicina. Quem sabia fazer uma conta de somar ia ser engenheiro - não é o meu caso; eu faço uma conta de somar seis vezes, encontro seis resultados diferentes, todos seis errados. Quem agüentava espiar para um defunto, de manhã, ia ser médico. E quem não dava para nada ia estudar Direito - era o meu caso. (SUASSUNA apud NEWTON JÚNIOR, 1999, p. 37-38).

É assim que conhece Lourenço da Fonseca Barbosa, mais conhecido como Capiba, José Guimarães Sobrinho, Maria Teresa Leal, Epitácio Gadelha, Ana Canen, Rachel Canen, Milton Persivo, José Lins, Alaíde Portugal, Clênio Wanderley, Dulce de Holanda, SebastiãoVasconcelos, FiladelfaLoureiro, ElaineSoares, Salustiano Gomes Lins, Fernando José da Rocha Cavalcanti, José de Morais Pinho, Galba Marinho Pragana, Ivan Pedrosa, Joel Pontes, Gastão de Holanda, Genivaldo Wanderley, Aluísio Magalhães, Hermilo 
Borba Filho e José Laurênio de Melo (esses dois últimos exerceram uma influência considerável na formação de Suassuna).

Sob a liderança de Hermilo Borba Filho, o grupo funda, em 1946, o Teatro do Estudante de Pernambuco (TEP) ${ }^{1}$, que passa a servir, durante anos, de laboratório para várias experiências e descobertas artísticas. As atividades desenvolvidas pelo grupo seriam realizadas em três direções. Em primeiro lugar, levar o teatro ao povo, com espetáculos em praças públicas, teatros suburbanos, centros operários, pátios de igrejas, orfanatos e outras instituições. Outro objetivo do grupo era trazer aos componentes do TEP debates sobre a problemática teatral, através de estudos de importantes autores da dramaturgia universal, como shakespeare, Ibsen, Tchecov, Sófocles, Ramon Sender e Garcia Lorca, além de observações e pesquisas de elementos das várias formas de espetáculos populares da região. Por último, o grupo previa o incentivo à criação de uma literatura dramática voltada para as raízes da realidade brasileira, particularmente, a nordestina.

O TEP estimulou, fundou e encenou as primeiras manifestações de uma dramaturgia nordestina, que representa o que nossa tradição, nossos contos e mitos, nosso romanceiro e nosso espírito populares têm de mais verdadeiro e profundo. Embora tendo o teatro como atividade básica, realizou, sem dinheiro nem apoio, um movimento artístico completo, total, que alcançou quase todas as artes, sendo escolas de autores, encenadores, cenógrafos, mas também de pintores, músicos, poetas, novelistas, estudiosos das tradições e artes do povo; criou uma editora e lançou livros. (BORBA FILHO apud SANTOS, 2000, p. 102-103).

1 Daqui em diante, utilizaremos a sigla TEP para nos referir ao Teatro do Estudante de Pernambuco. 
Hermilo Borba Filho, mais experiente que os outros participantes do grupo, foi de extrema importância para os jovens intelectuais que participavam do TEP. Tal liderança e importância podem ser comprovadas em um depoimento de Suassuna que atesta o trabalho de Borba Filho ao introduzir elementos que mais tarde seriam aprofundados e concretizados pelo Movimento Armorial.

No que se refere à nossa geração, não há ninguém que se possa comparar a Hermilo Borba Filho como abridor de veredas e apontador de caminhos. De fato, foi com sua lição mais do que com a de qualquer outro, que todos nós encontramos, quando, aí por 1946, procurávamos uma poesia, uma pintura, um romance, uma música e, sobretudo, um teatro, que, ligando-se à tradição do Romanceiro Popular Nordestino, não nos deixassem presos aos limites, para nós por demais estreitos do Regionalismo. Foi, assim, do movimento do Teatro do Estudante de Pernambuco - que se identifica única e exclusivamente com Hermilo Borba Filho - que surgiu, entre outras coisas, a primeira Poesia brasileira ligada a nossos mitos, a nossos animais fabulosos, a nossos heróis, aos Cangaceiros. O que nós desejávamos e buscávamos, sob o ensinamento de Hermilo Borba Filho, era uma Poesia quente e viva que, ainda palpitando do sangue generoso e popular de onde saíra, pulsasse dentro de nós, ao ritmo do nosso próprio sangue, ao galope de nossos cavalos magros, ágeis e ardentes como os árabes, ao riso dos nossos Circos, aos cantares épicos, trágicos ou sardônicos dos 
nossos Cantadores, ao gume solene e cruel das nossas Cantadeiras de excelências - essas fúrias e harpias sertanejas, impassíveis como carpideiras e trágicas como as figuras dos coros gregos. (SUASSUNA apud NEWTON JÚNIOR, 1999, p. 42).

Através do contato com Hermilo Borba Filho, Suassuna passou a tomar conhecimento do teatro e poesia de Garcia Lorca, que representou um marco na sua obra. Marco esse que se deu por conhecer, pela primeira vez, um grande nome erudito que se fundamentava na cultura popular. Nesse caso, a Espanha, mais precisamente a região da Andaluzia, onde se constata o mundo rural que Lorca representa. As descrições feitas pelo autor espanhol, com base em elementos de sua cultura popular (cavalos, ciganos, bois e, principalmente, o romanceiro popular ibérico), aproximam ainda mais Suassuna da sua realidade, o Sertão, onde já havia passado toda sua infância e, assim, já conhecia tão bem (NEWTON JÚNIOR, 1999, p.43).

De acordo comJosé Laurenio de Melo, outra influência bastante presente na formação de Suassuna se deu através do desenvolvimento obtido no TEP, quando o precursor do Movimento Armorial (nesse período, um mero estudante de Direito) trilhou os primeiros passos rumo ao sucesso como dramaturgo, exercitando e descobrindo suas potencialidades criadoras. O TEP teve vida de 1946 a 1952 (ano em que Hermilo Borba Filho se transfere para São Paulo), parando suas atividades, em razão das dificuldades financeiras. Diplomado no ano de 1950, Suassuna encontrou no TEP o embrião de todo seu trabalho posterior, alavancando o seu estudo em relação à poesia popular.

Com o fim do TEP, uma outra experiência, em 1959, leva Suassuna novamente a compor um grupo em prol da cultura popular, o Teatro Popular do Nordeste (TPN). Juntamente com Hermilo Borba Filho, esse grupo assume o papel de centro cultural já ocupado pelo grupo anterior. 
Já em 1961, Suassuna e boa parte da intelectualidade de esquerda em Pernambuco, a exemplo do educador Paulo Freire, os pintores e escultores Francisco Brennand e Abelardo da Hora, Aloísio Falcão, Germano Coelho e novamente Hermilo Borba Filho fundam o Movimento de Cultura Popular (MCP), através do apoio do então prefeito de Recife, Miguel Arraes. Essa nova experiência ganhou âmbito nacional rapidamente e teve apoio de várias entidades de esquerda no país, como por exemplo, a União Nacional dos Estudantes (UNE). As atividades realizadas pelo MCP só foram extintas com o golpe de 1964, tendo muitos dos seus integrantes presos. Suassuna continuou, meses mais tarde, com as atividades no Teatro Popular do Nordeste, até que ele e Hermilo Borba Filho divergiram na forma de atuação do grupo.

Todas essas experiências vieram a servir de laboratório para o cargo de diretor que Suassuna viria a exercer no Departamento de Extensão Cultural da Universidade Federal de Pernambuco, em 1969. No $\mathrm{DEC}^{2}$, ele e outros pesquisadores sintetizaram os estudos, transformando aquele departamento num verdadeiro laboratório de pesquisa multidisciplinar sobre as raízes da cultura brasileira, o que serviria de base para o Movimento Armorial. Sobre as atividades realizadas no DEC, o violonista Jarbas Maciel declarou:

A volta às raízes populares nordestinas nos coloca em contato com a música renascentista e barroca, para não falar das constantes medievais, veiculadas pela música sacra que os missionários faziam misturar-se à música primitiva dos índios catequizados. Tudo isso está curiosamente preservado nos verdadeiros 'fósseis musicais' que estamos encontrando na música nordestina do Sertão, do Agreste e da Zona da Mata. (DIDIER, 2000, p. 37-38).

2 Daqui em diante, faremos uso da sigla DEC para nos referir ao Departamento de Extensão Cultural da Universidade Federal de Pernambuco. 
Contando com o trabalho de alguns talentos desconhecidos, como também de famosos como o maestro Guerra Peixe, o DEC, além das pesquisas orientadas aos estudos das raízes de nossa cultura, prestou assistência a artistas populares atuantes em outros setores artísticos, que não fosse a música. Dessa forma, artistas envolvidos com a literatura de cordel, a xilogravura e a escultura passaram a desenvolver suas atividades de forma mais tranquila, exercitando suas potencialidades.

Durante sua permanência na diretoria do DEC (que se estendeu de 1969 até setembro de 1974), além do apoio aos artistas populares, através de patrocínios e impressão de álbuns e "folhetos" de gravuras, Suassuna conseguiu concretizar o sonho da Arte Armorial: "pode-se dizer, porém, que ela só foi reunida de maneira deliberada e consciente depois que se tornou o principal elemento dinamizador dos trabalhos do Departamento de Extensão Cultural da Universidade Federal de Pernambuco" (NEWTON JÚNIOR, 1990, p. 113). Com o término de suas atividades à frente do DEC, encerra-se também a fase dita experimental do Movimento, que será apresentada mais adiante, juntamente a outras duas fases históricas do Armorial.

Pode-se dizer que o nome Arte Armorial antecedeu o Movimento Armorial. Isso porque, muito antes do lançamento oficial do Movimento, vários artistas, nos diversos segmentos artísticos, já executavam seus trabalhos voltados para aquela ideia da busca de uma arte brasileira erudita, calcada nas raízes populares da nossa cultura.

O Movimento não reúne artistas populares, mas artistas cultos que recorrem à obra popular como a um 'material' a ser recriado e transformado segundo modos de expressão e comunicação pertencentes a outras práticas artísticas. Esta dimensão culta e até erudita manifesta-se tanto na reflexão teórica, desenvolvida em paralelo à criação, quanto na multiplicidade das referências culturais. (SANTOS, 2000, p. 98). 
Suassuna não fazia qualquer tipo de restrição à liberdade criadora de cada artista, pois, apesar de uma direção a ser seguida, vários são os caminhos, todos convergindo para um mesmo ponto. Coube ao criador do Armorial, então, a reunião desses vários artistas, ao identificar pontos em comum e tendências paralelas em torno de algo maior, o Movimento.

\section{Armorial: $o$ adjetivo que se transformou em substantivo}

A escolha do nome armorial foi apresentada ao público pela primeira vez, no lançamento oficial do Movimento, em 18 de outubro de 1970 (um domingo), na igreja barroca de São Pedro dos Clérigos, localizada no bairro de São José, em Recife, através do texto "Arte Armorial".

Em nosso idioma, 'armorial' é somente substantivo. Passei a empregá-lo também como adjetivo. Primeiro, porque é um belo nome. Depois porque é ligado aos esmaltes da Heráldica, limpos, nítidos, pintados sôbre metal ou, por outro lado, esculpidos em pedra, com animais fabulosos cercados por folhagens, sóis, luas e estrelas. [...] Em nosso país, a Heráldica é uma Arte essencialmente popular e não burguêsa. A unidade nacional brasileira vem do Povo, e a Heráldica popular brasileira está presente desde os ferros de marcar bois e os autos de Guerreiros, do Sertão, até as bandeiras das Cavalhadas e as côres azuis e vermelhas dos pastoris da Zona da Mata. Desde os estandartes de Maracatus e Caboclinhos, até as Escolas de Samba, as camisas e bandeiras dos clubes de futebol do Recife ou do Rio. (SUASSUNA apud NEWTON JÚNIOR, 1990, p. 129-130). 
Segundo Suassuna, a escolha deu-se por dois motivos. O primeiro, pela plasticidade do nome, ou seja, a beleza da própria palavra. O outro, porque na sua visão, a heráldica, no Brasil, representa uma arte eminentemente popular, existente desde os ferros de marcar boi do Sertão nordestino, até os estandartes, as agremiações carnavalescas, as bandeiras e escudos dos clubes de futebol. Em determinadas ocasiões, Suassuna acrescentava uma terceira justificativa que o teria influenciado na escolha do nome. Seria a curiosidade despertada nas pessoas devido ao desconhecimento do significado do termo, como no caso de uma entrevista concedida, em 1971, ao jornal gaúcho Correio do Povo. Questionado sobre o que motivou a escolha do nome armorial, ele respondeu: "Primeiro, porque é bonito. Segundo, porque sendo um nome estranho, o pessoal pergunta como você - 'o que é?' - e ouvida a explicação, não esquece mais. Terceiro, porque significa esta palavra a coleção de brasões, emblemas e bandeiras de um povo" (SUASSUNA apud NEWTON JÚNIOR, 1999, p. 88).

"Três Séculos de Música Nordestina: do Barroco ao Armorial". Com esse título, a Orquestra Armorial de Câmara, junto a uma exposição de gravuras, pinturas e esculturas armorialistas, dava início, pelo menos oficialmente, ao Movimento Armorial. Durante a realização do concerto na igreja São Pedro dos Clérigos, no Recife, foram tocadas, como o próprio título sugere, peças do Barroco e peças Armoriais. Inicialmente, foram executadas obras dos compositores pernambucanos do século XVIII José de Lima e Luís Álvares Pinto, descobertas durante estudos das pesquisas armoriais e que foram transcritas, respectivamente, por Luis Soler e Benjamim Wolkoff. Na segunda parte do concerto, dedicada às composições armoriais, foram apresentadas obras de Jarbas Maciel, Clóvis Pereira e Cussy de Almeida, além de outras duas composições de dois compositores já famosos que engrandeceram muito o Movimento Armorial, "Galope", de Guerra Peixe, e a suíte em três movimentos, "Sem Lei Nem Rei”, de Capiba. 
A respeito do lançamento oficial do Movimento, a imprensa pernambucana limitou-se a publicar algum material apenas uma semana após o evento, através do Jornal do Commercio. Já o Diário de Pernambuco, apenas no dia 28, ou seja, dez dias depois, publicou um artigo de Flávio Guerra intitulado "Um Concêrto da Orquestra Armorial de Câmara”. Assim, ele finalizava o artigo:

Valeu a pena ir assistir o concerto na Igreja de São Pedro dos Clérigos. Ficou até bem a apresentação ali da música armorial nordestina. Alguma coisa que se plantou mui significativamente nessa demonstração: a certeza de que Pernambuco está outra vez na liderança dos movimentos culturais de escóla no Brasil. Um dia outras orquestras armoriais irão surgir, no milagre da conscientização artística de um povo dando vivescência ao modesto, extrapolando-o para os grandes salões, tirando-o da modesta indumentária do chapéu de couro, para as sedas e os trajes finos. Noite inesquecível mesmo aquela vivida na Igreja de São Pedro, neste Novo Recife. (NEWTON JÚNIOR, 1990, p. 124).

Outra cobertura da imprensa local de forma mais significativa aconteceria em julho de 1971, com a repercussão no Sul e Sudeste da primeira excursão da Orquestra Armorial de Câmara. Apresentando-se no programa "Concertos para a Juventude", realizado pelo MEC, em convênio com a Globo do Rio de Janeiro, na Sala Cecília Meireles e, por último, na Universidade Federal do Rio Grande do Sul (UFRS), a Orquestra Armorial (junto às explanações de Suassuna realizadas através de desenhos, pinturas, gravuras, livros e outras artes armoriais sobre o início e as primeiras realizações do Movimento) recebeu críticas positivas que atestavam o sucesso das apresentações. 
Referindo-se especificamente à Arte Armorial, Eurico Nogueira França escrevia, no 'Correio da manhã':'O forte caráter das composições apresentadas vem mais uma vez descerrar-nos os filões de brasilidade criadora...- como os há, também, por exemplo, na dramaturgia do próprio Suassuna, que fêz comentários tão interessantes, com 'slides', sôbre aspectos musicais e não musicais do programa. É mais do que nunca oportuno ressaltar êsses veios preciosos, porque a nossa música de concerto, nas suas expressões de vanguarda, tende para manifestações abstratas e não nacionais, sob o pretexto principal de que o nacionalismo está superado nos centros musicais do exterior... A essa altura, um banho de sentimento brasileiro é altamente salutar... Ariano Suassuna, com a naturalidade saborosa e picaresca da sua fala, passou estão a ser o animador da noite, explicando as raízes do movimento armorial e comentando cada uma de suas peças. Estas foram devidamente valorizadas pela orquestra, cujos arcos são de primeira ordem, e trouxe-nos exteriorização sugestivamente impecável de todo o programa, sob a regência do maestro Clóvis Pereira... Audição de perfeita originalidade teve rumoroso e merecido sucesso'. (NEWTON JÚNIOR, 1990, p. 125-126).

Essa primeira excursão da Orquestra pode ser vista como o lançamento, em nível nacional, do Movimento Armorial, que passou a ser conhecido além das fronteiras nordestinas e teve, em seu idealizador, o referencial maior. 


\section{Experimental, Romançal e a atual fase do movimento armorial}

Nos seus mais de quarenta anos de existência, o Movimento Armorial atravessou fases distintas e bastante definidas. A primeira delas, a fase experimental, deu-se entre os anos de 1970 a 1975, quando Suassuna, através do DEC da UFPE, conseguiu realizar as pesquisas do que viria a ser, posteriormente, a música armorial. Sobre esta primeira fase do Movimento, alguns críticos contestariam os trabalhos armoriais alegando que artistas estariam se aproveitando do respaldo do Movimento através do DEC para divulgar, ou até mesmo, no caso de poetas e escritores, publicarem os seus trabalhos. A esse respeito Suassuna esclarecia:

na primeira fase, eu tive que começar várias coisas de qualquer maneira, fechando deliberadamente os olhos para certos adesismos, improvisações, artificialismos e equívocos, algumas vezes graves. [...] Bastaria o aparecimento de Antônio José Madureira, do Quinteto Armorial e da Orquestra Romançal Brasileira para justificar todo o resto do trabalho. Não esquecer, por outro lado, que Gilvan Samico prestigiou o Movimento, que se engrandeceu com seu nome, respeitado por todo mundo. o tempo vai depurando tudo: uns deixam o Movimento porque, de fato, nunca se interessaram verdadeiramente pela Cultura brasileira; outros porque, mais sensíveis às modas e às críticas, resolveram tomar outros caminhos; outros porque têm o temperamento mais solitário; e assim por diante. (SUASSUNA apud NEWTON JÚNIOR, 1990, p. 92). 
Com isso, Suassuna esclarece e confirma a existência de equívocos de alguns artistas que não entendiam ou se aproveitavam da situação, como deixava claro também num artigo escrito para a Folha de São Paulo sobre a Orquestra Armorial de Câmara, criada por Cussy de Almeida. Intitulado "Cussy de Almeida e o Armorial", o artigo dizia que Cussy "nunca entendeu - nem entende agora - a verdadeira importância e o verdadeiro significado da cultura popular brasileira" (NEWTON JÚNIOR, 1990, p. 137).

Com a estreia da Orquestra Romançal Brasileira no dia 18 de dezembro de 1975, no Teatro Santa Isabel, iniciava-se a fase romançal que se tornaria uma das mais produtivas do Movimento. Sobre a adequação do termo romançal, Suassuna explicava a escolha do nome:

romance ou romanço, era aquele amálgama de dialetos do latim 'mal-falado' e popular que deu origem às línguas românicas ou neo-latinas, inclusive o português, o provenha, o espanhol e o galego. Logo por economia, esses poemas, ao mesmo tempo líricos e épicos, escritos em romance passam a ser chamados somente de romances, e o nome se estende a toda a literatura narrativa em prosa ou em verso; são os romances de cavalaria, escritos em prosa, e as gestas, dos trovadores e troveiros, escritos em verso. (...) se a orquestra se chama Romançal, chama-se também Brasileira - e aí estão incluídos necessariamente o elemento mouro-africano e o indígena. Recorde-se ainda que na Península Ibérica, a língua dos Ciganos é o romani, e que foram os Ciganos - como tão bem Garcia Lorca soube entender - os principais 
responsáveis pelo trabalho de revitalização e recriação do Romanceiro espanhol medieval, dando-lhe, neste século, uma nova interpretação. (SUASSUNA apud DIDIER, 2000, p. 129-130).

É durante essa fase que surgem, além do trabalho da Orquestra Romançal, o lançamento do Balé Armorial (origem do atual Balé Popular do Recife) e a estreia, como teatrólogo, de Antonio Carlos Nóbrega, com o espetáculo "Bandeira do Divino" (1976). Outros trabalhos, nesse período, atestaram que o Movimento Armorial não estava restrito às fronteiras da Região Nordeste, como diziam alguns críticos. Foi o caso do lançamento d'A Guerra do Reino Divino, um trabalho em história em quadrinhos de Jô Oliveira, baseado no Romance d'A Pedra do Reino, que seguia de perto as propostas da gravura e da pintura armoriais. Outro trabalho, que seguia as orientações do Armorial e que também ultrapassava as fronteiras da região, diz respeito ao lançamento do elepê A Fantástica Viola de Renato Andrade na Música Armorial Mineira, de autoria do mineiro Renato Andrade (NEWTON JÚNIOR, 1999, p. 93).

Após esse período, iniciou-se uma fase de absoluto silêncio por parte de Suassuna em relação aos trabalhos voltados à arte armorial. Alguns arriscaram que esse período, compreendido entre 1981 (data que o Diário de Pernambuco publicou o artigo "Despedida") e 1987, representava o fim do Armorial. No entanto, esses pouco mais de seis anos, representavam um descontentamento por parte de Suassuna em relação às constantes críticas e incompreensões das várias partes, externas ou internas, do próprio Movimento, mas significava também um aprofundamento da estética armorial. Com isso, começava a se estruturar uma terceira geração de artistas, que se faziam presentes naquelas propostas iniciadas já nos primeiros passos de Suassuna no campo das artes, e que, até os dias de hoje, dão prosseguimento e mantêm acesa a chama do Movimento nas várias manifestações artísticas. 
Faz-se importante ressaltar que ao longo da sua história, os momentos mais fecundos do Movimento Armorial coincidiram com a participação de Ariano Suassuna na esfera política. Foi assim em 1969, quando assumiu a direção do DEC, dando início ao que iria ser mais tarde o Movimento Armorial. Já entre os anos de 1975 e 1978, ao assumir o cargo de secretário de Educação e Cultura do Recife (na gestão do prefeito Antônio Farias), criou o Balé Armorial do Nordeste. Mais tarde, entre os anos de 1995 e 1998, foi nomeado secretário de Cultura do Estado de Pernambuco, pelo então governador Miguel Arraes. Nomeado secretário do executivo de Cultura do Estado de Pernambuco pela segunda vez em 2007, o escritor deixou claro que iria adotar uma política voltada para os ideais armoriais. Basta lembrar que justamente nesse ano de 2007, o escritor escreveu mais um capítulo na música armorial, ao reativar a "Camerata Armorial".

Nessa sua segunda participação a frente da pasta de Cultura de Pernambuco, Ariano Suassuna realizou um trabalho de interiorização no Estado, percorrendo um total de $25.409 \mathrm{Km}$ com suas aulas-espetáculo, de Araripina e Petrolina à Região Metropolitana do Recife. Ao todo, 117 apresentações entre as aulas-espetáculo "Nau", "A Cadência, o Castelo e a Cantoria" e "Chamada ao Piano". Se no primeiro Suassuna tratava de questões que envolvem a construção da identidade brasileira a partir das manifestações culturais, em "A Cadência, o Castelo e a Cantoria" o escritor contemplava a poesia popular nas suas discussões, explorando vários gêneros da cantoria. Já "Chamada ao Piano" era uma celebração à produção em piano de compositores do Estado que registraram seus nomes no cenário cultural entre o fins do século 19 e início do século 20.

A síntese dessas aulas está representada na aula-espetáculo "Romançário", realizada no dia 6 de dezembro de 2010, em celebração aos quatro anos de gestão. Com acesso gratuito, 
a aula contou com a participação da pianista Elyanna Caldas e de 13 artistas, sendo cinco músicos, dois cantores, um cantador e cinco bailarinos. A escolha do Teatro Santa Isabel, em Recife, para o encerramento das suas atividades a frente da Secretaria Especial de Cultura do Governo do Estado não foi à toa. Afinal, foi nesse mesmo espaço, no ano de 1946, que Ariano Suassuna, então com 19 anos de idade, realizou sua primeira aula-espetáculo. Já em 2011, Ariano Suassuna dá continuidade ao seu trabalho em prol da cultura do Estado de Pernambuco ao integrar a equipe do Governo do Estado, assumindo o papel de secretário-chefe da Assessoria Especial do governador Eduardo Campos, mantendo, mais uma vez, uma relação estreita com a esfera política.

\section{A Música Armorial}

Sendo a música uma das atividades de maior repercussão nacional do Movimento Armorial, e em se tratando de um estudo da obra de Antonio Carlos Nóbrega (o que significa dizer que é na música que vai se encontrar a base maior do seu trabalho), faz-se necessário uma avaliação mais específica sobre como essa atividade evoluiu e fez crescer o Movimento.

Inicialmente, as atividades em torno da música armorial foram realizadas através de um Quinteto fundado por Suassuna em 1969. Com uma estrutura baseada no "terno" de Mestre Ovídio, composto por dois pífanos e duas rabecas, a primeira experiência armorial no campo da música contava com "duas flautas - por causa dos dois pífanos do 'terno' - um violino e uma viola-de-arco - por causa das duas rabecas - e percussão, por causa da 'zabumba"' (SUASSUNA, 1974, p. 57).

Esse primeiro Quinteto, no entanto, não atendia aos anseios de Suassuna. Além da exclusão dos "instrumentos rústicos" por "instrumentos refinados", ainda se fazia o uso da bateria em vez 
da "zabumba", para a percussão. Outro aspecto que não satisfazia Suassuna era a ausência da viola sertaneja, considerada por ele fundamental e que, vez por outra, era suprida quando, a convite de Jarbas Maciel e Cussy de Almeida, o violonista Henrique Annes procurava, com o violão, preencher a falta da viola dos cantadores.

Paralelamente às atividades do Quinteto, o violonista Cussy de Almeida fundou a Orquestra Armorial de Câmara, que inclusive, incorporou os membros do Quinteto e que, por sugestão do próprio Cussy a Suassuna, participou do lançamento oficial do Movimento ocorrido com a Orquestra e não com o Quinteto. As atividades, então, ficaram divididas. Enquanto a Orquestra encarregava-se da execução das músicas, com os membros do Quinteto integrados a ela, Suassuna continuava supervisionando o trabalho dos músicos e encomendando as partituras para a Orquestra.

Mesmo sendo a pesquisa das tradições populares a base para as experimentações da música armorial, a Orquestra Armorial não incorporava instrumentos de cunho popular. A esse respeito declarou Cussy de Almeida:

a idéia inicial minha, do Suassuna, do Clóvis Pereira, do Guerra Peixe era a utilização de certos instrumentos mais característicos da cultura popular, como a rabeca, através de instrumentos clássicos da cultura européia. Até hoje, nenhum luthier conseguiu explicar por que duas rabecas populares, feitas da mesma madeira, nunca têm o mesmo som e a mesma tonalidade, ainda que afinadas exatamente iguais. Isso nos levou a utilizar o violino e a viola para representar essas duas rabecas. (DIDIER, 2000, p. 111). 
Enquanto Cussy de Almeida preocupava-se mais com a unidade do som da Orquestra, Suassuna, a exemplo da experiência anterior com o Quinteto, acreditava que os instrumentos populares deveriam estar presentes na música armorial, dando-lhe uma característica mais próxima da realidade nordestina. Esse ponto de vista de Suassuna resultaria em discordâncias dentro do próprio Movimento. As divergências entre Suassuna e Cussy de Almeida, além de provocarem uma série de polêmicas em torno do Movimento Armorial, concretizaria a formação de um segundo quinteto, o Quinteto Armorial. Fundado por Suassuna, essa nova experiência da música armorial visava contemplar os anseios do criador do Movimento, aproximando à cultura nacional, uma "originalidade" da tradição musical brasileira. No início, o Quinteto Armorial contava com Antônio José Madureira que, além de coordenador do grupo, tocava viola-sertaneja ${ }^{3}$; Edilson Eulálio, no violão; Antonio Carlos Nóbrega, na rabeca e no violino; Egildo Vieira, na flauta e pífano; e Fernando Torres Barbosa tocava berimbau.

A apresentação de estreia do novo Quinteto aconteceu na Igreja Rosário dos Pretos, em Recife, no dia 26 de novembro de 1971. Além do Quinteto Armorial, houve também uma exposição de artes plásticas com esculturas em madeira, cerâmica, desenho e tapeçaria. O programa de apresentação foi dividido em três partes. A primeira destinada à música barroca europeia, que foi apresentada com uma sonata de Scarlatti,

3 Para o bom desempenho de Antônio José Madureira com a viola-sertaneja, já que seu instrumento por formação é o violão, foram trazidos do interior dois Cantadores. Em pouco tempo, Zoca, como é mais conhecido Antônio José Madureira, obteve um ótimo desempenho tocando a violasertaneja e se mostrava entusiasmado com o instrumento.

4 Conhecido também como "berimbau de lata", o marimbau, bastante utilizado por músicos de feira, era constituído por um arame, pregado a uma tábua e esticado por cima de duas latas que servem de caixa de ressonância, de forma que se toca transversalmente. 
uma contradança do compositor espanhol do século XVIII, Fernando Ferandieri, um andante de Vivaldi e um allegro de Haendell. A segunda parte trabalhava a música barroca brasileira, sendo executadas uma peça de Luís Alvares Pinto e outra de José de Lima. Na terceira e última parte da apresentação, destinada à música armorial, foram executadas músicas de autoria de Antônio José Madureira como, "Improviso", "Repente Armorial", "Chamada"; e outras duas peças armoriais de José Generino Luna.

Segundo Suassuna (1974, p. 59), a utilização de elementos considerados arcaicos do povo tinha um caráter "didático" inicial. "Era um modo de, digamos assim, "reeducar" nossos músicos, encaminhando-os a um despojamento, a uma pureza e a uma estrutura musical brasileira que os afastassem dos padrões convencionais europeus". Outra observação de Suassuna esclarece a proposta do repertório de apresentação do Quinteto. De acordo com ele, a importância da arte barroca, principalmente o barroco ibérico, para a arte armorial davase através do espírito medieval e pré-renascentista, com seus "cantares", que aqui estavam presentes nos séculos XVI, XVII e XVIII (DIDIER, 2000, p. 113).

De acordo com o pesquisador e crítico de música José Ramos Tinhorão (apud DIDIER, 2000, p. 44), o Movimento Armorial, através do Quinteto Armorial, conseguiu realizar a integração e a singularidade sugeridas por Suassuna, ao fundir o universal e o regional, o popular e o erudito:

se a descoberta de novos lençóis de petróleo anuncia a perspectiva de um desenvolvimento independente da ajuda das multinacionais, a revelação musical do Quinteto Armorial vem mostrar que, das profundezas da criação popular, também se pode tirar uma cultura autenticamente nacional. (SUASSUNA apud DIDIER, 2000) 
Outra experiência da música armorial se daria em 1975, quando Suassuna é empossado secretário de Educação e Cultura de Recife e estabelece como uma de suas metas a criação da Orquestra Armorial Brasileira que, mais tarde, se tornaria Orquestra Romançal Brasileira, para distinguir da Orquestra Armorial de Câmara. Sob a regência de Antônio José Madureira, a Orquestra teve sua estreia no dia 18 de dezembro de 1975, no Teatro Santa Isabel, em Recife, marcando a chamada fase Romançal do Movimento.

No seu repertório, a Orquestra Romançal Brasileira apresentou quatro composições de Antônio José Madureira e outras três músicas de origem ibérica, de compositores anônimos do século XVI. Essa outra atividade da música armorial estava intimamente ligada às propostas do Quinteto Armorial, só que dessa vez, com a constituição de uma orquestra nacional ligada às tradições populares, o que representava de perto o objetivo maior do Movimento: uma cultura nacional, a partir das nossas raízes populares.

Procuravam-se, no passado e na tradição medieval, as raízes populares. Da viola sertaneja, o grupo descobriu uma ligação com o cravo, instrumento da música barroca, realizando algumas experiências com composições. A pesquisa também contemplou os trovadores da Idade Média e, com a participação de alguns poetas, criou uma 'embalada', mistura de embolada e balada, como os 'desafios' que existem no Nordeste. Recitavam o texto com ilustração musical, utilizando contrabaixo e percussão. (DIDIER, 2000, p. 111).

A partir das várias experiências em torno da música armorial, o Quinteto realizava estudos sistemáticos dos sons dos instrumentos populares, fazendo associações a instrumentos eruditos. 
Já no ano de 1996, surge a Camerata Armorial, numa parceria entre Suassuna e o maestro Rafael Garcia. O grupo surgiu durante a administração de Suassuna como secretário de Cultura do Estado de Pernambuco e só agora no ano de 2007, depois do escritor ter sido reconduzido ao cargo, é que retomou suas atividades. Na sua reestreia, a Camerata Armorial executou peças clássicas dos primeiros anos do Movimento, assinadas por Capiba, Jarbas Maciel e Clóvis Pereira, a exemplo da música Mourão, de autoria de Guerra Peixe.

\section{Antonio Carlos Nóbrega e o Movimento Armorial}

Ao contrário de outros movimentos, que se caracterizavam pela primazia do intelecto, desvencilhando-se da presença mítica, como foi o caso de alguns movimentos literários de meados do século, o teatro do absurdo e, até certo ponto, o teatro de Brecht, o Armorial pretende recolocar o mito na vivência da arte. Isso se evidencia no princípio Armorial de trabalhar com a integração das artes, afastando-se "deliberadamente de uma arte de tendência racional para abraçar o orgânico, o multiforme, e o contraditório, o espírito luxuriante de festa e cor bastante presente em nossas manifestações populares: do bumba-meu-boi às cavalhadas, do mamulengo aos circos mambembes" (NEWTON JÚNIOR, 1999, p. 109).

Esse estreitamento das artes, sobretudo nos espetáculos populares, faz com que os armorialistas tenham uma linguagem privilegiada, fazendo do espetáculo popular um espetáculo total, uma festa que magnetiza o público, através de uma projeção da realidade onde ele se encontra e se identifica. Nessa perspectiva é que surge Antonio Carlos Nóbrega, como desdobramento da experiência armorial, reunindo música, poesia, dramatização, dança e cenografia, através de uma vasta carreira 
teatral (BITTER, 2000, p. 23), além de seus espetáculos recitais, que identificam as diversas faces de um artista de mais de 30 anos de carreira dedicada aos ideais do Movimento Armorial.

Considero Nóbrega um artista da maior importância. Na década de 70, eu escrevi um artigo dizendo que os verdadeiros atores brasileiros não deviam ser meros 'dizedores' de palavras. O ator brasileiro tinha que saber dançar, cantar, andar em cima das mãos, se necessário, enfim, ter um corpo preparado. Eu nunca esperei, ainda em vida, ver isso. E vi com Nóbrega. Ele toca, ele canta, ele representa, ele dança. Ele realizou aquele ideal de ator que eu tinha. (SUASSUNA, 2002, p. 20).

Filho de classe média, Antonio Carlos Nóbrega, nascido em Recife, no ano de 1952, teve sua infância em várias cidades do interior pernambucano, mas, curiosamente, só veio ter contato com o imaginário que seu trabalho expressa aos 12 anos de idade, quando numa viagem com o seu pai à cidade de Patos, no Sertão paraibano, teve a oportunidade de escutar pela primeira vez um cantador. Naquele período, Nóbrega já começava a demonstrar sua vocação para a música. Logo, ele e suas três irmãs foram colocados para estudar música e, paralelamente aos rígidos estudos exigidos pela música acadêmica, mantinham um conjunto musical que tinha como repertório músicas da Jovem Guarda, Beatles, Roberto Carlos e, até mesmo, um pouco da Tropicália.

Foi na Escola de Belas-Artes, em Recife, com o professor catalão Luis Soler, que Nóbrega teve sua formação de violonista solidificada. Já no final dos anos 60, participava da Orquestra de Câmara da Paraíba e da Orquestra Sinfônica do Recife. Seu ingresso no mundo armorialista deu-se, em 1972, quando, 
tocando um concerto de violino de Bach, com a orquestra sinfônica, conheceu Suassuna. Convidado pelo precursor do Movimento Armorial a integrar o Quinteto por ele criado, o jovem de 18 anos, que já tinha uma formação musical cristalizada (SUASSUNA, 2002, p. 20), passou do violino para a rabeca e mergulhou no rico universo da cultura popular, que nem lhe havia sido ensinado nas escolas de música nem muito menos apresentado através do rádio, como afirma ele próprio numa entrevista coletiva concedida à imprensa paraibana, no dia 21 de agosto de 2003, quando em Campina Grande se apresentou com a aula-espetáculo Sol a Pino. ${ }^{5}$

A partir daí comecei a conhecer a música do povo brasileiro e para tocar rabeca no grupo, tive que conhecer o rabequeiro, que até então não conhecia. Não só conheci o rabequeiro, como conheci o brincantepopular, o brincante do cavalo-marinho, o tocador de alfaia, o cantador. Enfim, toda essa exuberância de músicos, brincantes, dançarinos que povoam as praças e ruas

5 Forma de apresentação encontrada por Nóbrega, na qual não se necessita de uma grande estrutura para a exibição do espetáculo. Ao longo da aula-espetáculo, o artista, através de cantigas, romances, martelos, cocos, acompanhando-se da rabeca, viola de cantoria, bandola, violão (tradicional ou tenor) e pandeiro, incursiona pelo universo das danças populares, apresentando singularidades de uma linguagem corporal brasileira, através da capoeira, do frevo, do maracatu, de caboclinhos, do coco, entre outras. É também uma conversa bastante próxima ao público, na qual Nóbrega vai relatando e comentando temas como arte universal, arte regional, diferentes linguagens de dança e cultura popular. Esse estreitamento de espaço entre a platéia e o artista é ponto de partida para o título do espetáculo: "Sol a Pino", já que como o próprio nome diz: quando o sol está a pino, está tudo às claras, uma metáfora que evoca o espírito solar e confraternizador presente na alma coletiva. 
do nosso país que tanto me seduziu e continua a seduzir. Representou a base maior de tudo àquilo que eu vinha fazendo. (informação verbal) ${ }^{6}$. (SUASSUNA, 2002, p. 20).

Seu primeiro contato com a rabeca foi com um tocador do Ceará, chamado Cego Oliveira. Com essa aproximação, passou a frequentar grupos de artistas que estavam mais próximos de Recife e foi aí que conheceu, por exemplo, o Boi Misterioso de Afogados, do Capitão Antônio Pereira, figura já estudada por vários pesquisadores brasileiros, como Ariano Suassuna, Ascenso Ferreira e Hermilo Borba Filho.

Aos poucos, Nóbrega ia tomando conhecimento do rico universo da cultura popular. Foi assim queteve contato com o grande passista de frevo, Nascimento do Passo, passando a acompanhar suas aulas de dança. Conheceu também os Caboclinhos, que são grupos de espetáculos populares de reminiscências indígenas; fez amizade com os mestres e brincantes, aprendendo suas danças e seus toques; entre outras várias manifestações que passaram a enriquecer o trabalho do artista.

\section{Projetos e os princípios armoriais}

A partir de sua entrada para o Quinteto Armorial, Nóbrega passou a desenvolver seus próprios projetos, fundando inicialmente o Boi Castanho Reino do Meio-Dia. Foi precisamente em 1976, que ele começou a desenvolver um estilo próprio de concepção em artes cênicas, dança e música. Junto à Orquestra Romançal encenou dois espetáculos: Bandeira do Divino (marco da sua estreia como teatrólogo) e Mateus rabequeiro mágico e professor (1976). Ambos os espetáculos traziam toda a bagagem

6 Entrevista coletiva concedida por Antonio Carlos Nóbrega no dia 21/08/2003, em Campina Grande, no Teatro Municipal Severino Cabral. $\mathrm{Na}$ ocasião, o artista apresentava o espetáculo Sol a Pino. 
proposta pelo Movimento Armorial, introduzindo elementos do nosso espetáculo popular. Nesse sentido, a boneca Minervina se funde, ao mesmo tempo, com o espírito de figuras de bumbameu-boi como a Caterine, com mamulengos nordestinos, que aí já tem uma relação com os bonecos ventríloquos populares, como é o caso do Benedito, bastante conhecido nas feiras e pátios de mercados do Nordeste. Ou seja, elementos pertencentes ao popular que dialogam com elementos eruditos, a exemplo do mamulengo, que remonta a um tempo imemorável e consta em quase todos os países civilizados, com sua temática e sua representação vinda dos Autos Medievais. O mamulengo chegou ao Brasil via Portugal, no tempo do vice-reinado (séc. XVIII). É assim também com o bumba-meu-boi, que é uma rememoração das Tourinhas portuguesas, brincadas com bois simulados, sem dança e sem música. No caso da Minervina, trata-se de um romance de origem ibérica, que chegou ao Brasil no século XVII e, ainda hoje, é encontrado na região nordestina.

Depois, veio a criação de A arte da cantoria (1981), espetáculo que atendia as pretensões de Suassuna em relação ao processo de encenação e interpretação brasileiras, baseadas na literatura de cordel e nos espetáculos populares (CADENGUE, 1999, p. 50). A partir de então, seguia-se uma série de espetáculos que confirmavam toda estética armorial: O Maracatu misterioso (1982), Mateus Presepeiro (1985), o Reino do Meio-Dia - A dança das onças (1989), Figural (1990), Brincante (1992) e Segundas Histórias (1994); além de seus espetáculos recitais: Na pancada do ganzá (1995), Madeira que cupim não rói (1997), Pernambuco falando para o mundo (1998), o Marco do Meio-Dia (2000), Lunário Perpétuo (2002) e, mais recentemente, dois trabalhos em homenagem ao centenário do frevo, os dois volumes do Nove de Frevereiro (2006). Nesse período, o artista ainda apresentou outros dois trabalhos: em 1998, a aula espetáculo Sol a Pino e, no ano de 1999, o espetáculo Pernambouc, exibido no Festival D'Avignon, na França, especialmente para o público francês. Entre os anos de 2008 e 2010, o artista criou os 
espetáculos Passo e Naturalmente - Teoria e jogo de uma dança brasileira. Por esse último, recebeu o prêmio de melhor de 2009 na área de Dança - categoria Pesquisa, pela Associação Paulista dos Críticos de Arte (APCA). Também em 2010, Nóbrega estreou o espetáculo Minha Festa, oportunidade em que voltou a trabalhar na união da música, canto e dança.

A partir de passos, posturas, coreografias e acrobacias aprendidas em seus anos de convívio com artistas populares brasileiros, Nóbrega foi criando uma extensa linguagem gestual e corporal brasileira. Todo esse trabalho ganhou forma em "Figural", uma coletânea de arquétipos, na qual ele constrói uma dramaturgia e uma coreografia essencialmente nacional, ao colocar no palco nove personagens sem relação entre eles, mas que remetem a uma mitologia própria. Entre eles, o cançonetista, o multinstrumentista, o dançarino, o poeta e o prestidigitador. O espetáculo é, sobretudo, um meio de Nóbrega expor suas habilidades exímias de cantor, ator, dançarino, mímico (pantomima), instrumentista, bonequeiro e malabarista. Dessa forma, Nóbrega reflete a busca de estabelecer um elo entre a arte popular e a erudita, entre o desordenado e o disciplinado, o sutil e o espalhafatoso. As figuras que ele expõe, apresentadas como "pequenas iluminuras do baú da nossa memória coletiva", simbolizam a reunião de aspectos distintos que, pela arte, propagam-se sobre a realidade brasileira.

É aí, também, que surge Tonheta, personagem criado por Nóbrega a partir do velho "Faceta", palhaço animador do pastoril profano, presente nos espetáculos populares do Nordeste e figura trabalhada por Nóbrega, durante um longo período, nos seus vários espetáculos, sendo seu personagem brincante fixo. Tonheta pode ser visto como um misto de pícaro, bufão, palhaço, arlequim, vagabundo, entre outras coisas. "É uma espécie de colcha de retalhos desses tipos populares que povoam as ruas e praças do meu país, que me tocam profundamente deixando-me num estado de desordem interior cujos contrários dor e alegria se confraternizam misteriosamente" (NÓBREGA, 2004, s/p). 
O espetáculo Brincante representa o que seria a primeira parte da narrativa dos feitos e peripécias do personagem Tonheta. Para narrar as aventuras desse personagem andante, que percorre as estradas do mundo conduzindo uma velha carroça, Nóbrega criou uma dupla de atores ambulantes, João Sidurino (vulgo Mestre Siduca) e Rosalina de Jesus. A esses dois personagens coube narrar as proezas de Tonheta através da dança, teatro, música, mímica, circo e ventriloquismo. A saga "bufônica epopéia" de Tonheta teve sequência em Segundas Histórias.

O personagem Tonheta, num dos quadros de Figural, toca um complexo aglomerado de instrumentos de percussão, acionados através de pedais, que possibilitam ao ator ter as mãos e a boca livres para executar outros instrumentos, simultaneamente. Nóbrega-Tonheta faz tudo isso com um sorriso de quem brinca, fazendo da representação uma celebração da vida. 0 complexo e original instrumento tem um nome engraçadíssimo: 'Hipermultipolisintetizador DX 14 Ypisilone'. Nóbrega toca e improvisa, faz jogo com a plateia, que se delicia. (GEORGE MOURA apud CADENGUE, 1999, p. 53).

Tonheta continua presente, de alguma maneira, nos trabalhos recitais de Nóbrega. Quando não citado diretamente na letra da música, seu espírito zombeteiro se propaga junto às melodias e some ao confundir-se com instrumentos, num misto de gritos, zumbidos e vozes peculiares ao personagem.

\section{Nóbrega e seus trabalhos recitais}

Após o desenvolvimento de todas essas atividades, Antonio Carlos Nóbrega voltou a trabalhar com a música mais intimamente, criando espetáculos que procuravam refletir e traduzir as singularidades da cultura nacional. Seguia-se uma sequência de trabalhos recitais: Na Pancada do Ganzá, Madeira que cupim não rói (Na Pancada do Ganzá II), Pernambuco Falando Para o Mundo, 0 Marco do Meio-Dia, Lunário Perpétuo e, mais recentemente, Nove de Frevereiro. 
O disco Na Pancada do Ganzá foi um grande sucesso em todo Brasil e exterior, recebendo os prêmios "Shell", "APCA" e "Mambembe". O trabalho que representava uma reunião de cantos tradicionais do povo brasileiro foi dedicado à memória de Mário de Andrade e Chico Antonio.

Nome de uma consagrada marcha-de-bloco, do compositor pernambucano, Capiba, Madeira que cupim não rói apresenta uma segunda coletânea de frevos, cocos, maracatus e outras peças musicais. Com o espetáculo, Nóbrega realizou viagens pelas principais capitais brasileiras e procurava fortalecer a herança musical ibero-mediterrânea e afro-indígena, presente em todo o Brasil, principalmente, na região Nordeste, através das loas, toadas e cantigas tiradas pelos cantadores e brincantes dos espetáculos populares.

O título do espetáculo Pernambuco falando para o mundo faz referência ao slogan da Rádio Jornal do Commercio, que após sua inauguração, no ano de 1948, foi por muitos anos, a emissora brasileira de radiodifusão de maior alcance, com modernos transmissores que chegavam à grande parte da América do Sul, na América do Norte e na Europa. Daí o termo que dá nome a esse terceiro trabalho recital de Antonio Nóbrega, que congrega nesta produção uma enorme variedade de ritmos e manifestações culturais pernambucanas.

O disco seguinte, O Marco do Meio Dia, estreia em Lisboa, no ano de 2000, com a colaboração da primeira Comissão Nacional para as Comemorações do V Centenário do Descobrimento do Brasil. O espetáculo também se apresentou em Paris e Hannover, até chegar a várias cidades brasileiras. Foram

7 Na Pancada do Ganzá foi o nome dado por Mário de Andrade ao conjunto dos registros musicais que fizera durante suas viagens ao Norte e Nordeste do Brasil, nos anos de 1927 e 1928. 
utilizadas, nesse trabalho, histórias cantadas, com variadas formas poéticas e gêneros musicais que, ao longo dos tempos, foram aqui se tradicionalizando. Os arranjos e instrumentos utilizados na composição das músicas desse disco também se alicerçaram na diversidade musical brasileira, com conjunto de choro, orquestra de frevo e grupo de tambores. Como é de costume nas apresentações de Nóbrega, além da música cantada e instrumental, a dança e o teatro, principalmente, de máscaras e gestos, fazem-se presentes, demonstrando a diversidade cultural brasileira.

A estreia do espetáculo Lunário Perpétuo marcou os trinta anos do convívio de Nóbrega com a cultura popular. Nesse trabalho, os temas cancioneiro, romanceiro tradicional e a música para rabeca e violino são aprofundados e dividem espaço com os frevos e com as figuras incorporadas por Nóbrega, como é de costume. O título do disco e de uma de suas canções é versão abreviada do livro que circulou no Nordeste brasileiro até meados do século passado: Lunário e Prognóstico Perpétuo para Todos os Reinos e Províncias, de autoria do valenciano Jerônimo Cortez, cuja primeira edição remonta aos anos 1750.

Lunário Perpétuo, assim como os outros trabalhos, procura criar um constante diálogo entre dois universos distintos, que marcam a trajetória artística de Nóbrega, seja nos espetáculos musicais ou teatrais. Os constantes diálogos entre o festivo e o rígido, o dramático e o lírico, o sóbrio e o disparate, o espalhafatoso e o sagrado se caracterizam num processo de comunicação constante entre personagens de temperamentos opostos.

Os dois volumes do trabalho Nove de Frevereiro, lançados no final de 2006, representam uma "missão" estabelecida pelo próprio Nóbrega de resgate e registro de clássicos do ritmo pernambucano, com inúmeros frevos de bloco, canção, e de rua, 
com a participação de parceiros antigos, a exemplo de Bráulio Tavares e Wilson Freire. O trabalho apresenta um material significativo a respeito do frevo, com destaque para os registros fotográficos, informações e classificações de inúmeros passos do ritmo, além de histórias sobre a evolução do frevo no cenário artístico de Pernambuco.

Para se chegar a esse ponto de caracterização de palco, o seu aprendizado se desenvolveu desde os estudos de obras de escritores que registraram e interpretaram a cultura popular, como é o caso de Silvio Romero, Câmara Cascudo e Pereira da Costa, entre outros, até as cantigas, danças e versos de artistas populares, conhecidas por Nóbrega através de inúmeros encontros e viagens por diversas regiões brasileiras. Foi assim que ele passou a ter contato com Mestre Olimpio Boneca, do Crato; Mestre Kenura, de São Paulo; Capitão Pereira e Mateus Guariba, de Recife; para citar apenas alguns.

\section{Críticas ao Movimento Armorial}

Apesar de todo o reconhecimento e sucesso obtido pelo Movimento Armorial, críticas levantadas revelariam ângulos distintos a serem discutidos. Um desses questionamentos diz respeito à postura do Movimento. 0 não à vulgarização e ao processo de descaracterização se, por um lado preserva, por outro, torna a arte armorial desconhecida do grande público, tornando-se uma arte fundamentalmente elitista. A esse respeito, Suassuna (apud DIDIER, 2000, p. 46) deixava claro o sentido de sua obra: "Eu não escrevo para o consumo de classe nenhuma. Parto de formas de arte e literatura populares do Nordeste, porque gosto delas e porque, assim, expresso meu universo ficcional". 
De acordo com Nóbrega, o que acontece é que, muitas vezes, o Movimento Armorial era mal compreendido por acharem que seus seguidores se contrapunham aos meios de divulgação e tecnologia de divulgação. Na verdade, isso nunca foi dito, como afirma ele próprio:

Ninguém propõe um enclausuramento da divulgação da nossa cultura popular ou coisa semelhante; os meios de divulgação é que não se interessam muito [...] a tecnologia colocada a serviço da arte é uma maravilha. Quando a tecnologia se coloca a nosso favor, ela então engrandece, amplifica em poder da arte. Mas as vezes tem o poder de acachapar e fingir criação, artificializando-a e assim, em muitos casos, prestando um mal serviço. (informação verbal) ${ }^{8}$.

Ora, o Movimento Armorial não propunha um "não" à divulgação, nem tampouco um enclausuramento de um trabalho pouco divulgado. A não preocupação com as "paradas de sucesso" foi uma postura adotada diante de uma indústria que não possibilita a diversidade. Não é preciso voltar aos tempos áureos do Movimento para verificar esse processo. Basta olhar para os artistas que se "espremem" para conseguir um espaço no estreito funil da divulgação.

Em entrevista à revista Caros Amigos (2003, p. 38), quando questionado se hoje Nóbrega não pode ser entendido como uma cultura de massa elevada, Ariano Suassuna afirma:

Olhe, eu não tenho nada contra isso, não. Eu tenho contra é a concessão, está entendendo? Divulgação é ótimo. Eu não já deixei? Se quiserem contar um livro meu,

8 Entrevista com o músico Antonio Carlos Nóbrega, cf. nota 6. 
sem fazer concessões, natelevisão, eu deixo. Não só deixo como quero. Agora, fazer concessão, para deturpar... A primeira vez que fui procurado por uma pessoa de televisão, eu digo: 'Olhe, do jeito que a televisão anda aí, um dos dois vai ter que mudar o passo, e eu quero logo avisar que não sou eu'. E ele: 'Diga uma coisa que você não gosta'. 'Eu não vou admitir, por exemplo, que vocês façam com meus personagens a falsificação do sotaque nordestino como vocês fazem'. (CAROS AMIGOS, 2003, p. 23)

As divergências evidenciam uma outra visão daqueles que criticavam as ideias armoriais, uma visão mais "moderna" na qual o "pop" seria a maior demonstração de uma cultura popular, no sentido da divulgação e da popularização da cultura. Nesse aspecto, o escritor pernambucano Jomard Muniz de Britto, contrapondo-se à visão armorial, considera a valorização desses elementos "ultrapassados" como empobrecedores do entendimento da cultura brasileira.

Com uma formação voltada para outros movimentos, como o Cinema Novo, Bossa Nova e Semana de Arte Moderna de 1922, Muniz de Britto deixa transparecer a realização da sociedade industrial como algo positivo e inevitável, chegando a propor "supermercados de Arte; oportunidade de consumo para o grande público, laboratório vivo de criação artística” (BRITTO apud DIDIER, 2000, p. 48). Para ele, o processo de industrialização representaria um avanço. O conceito de cultura de massa, em sua opinião, além de democratizar o acesso, deixaria o caminho aberto para a integração da cultura.

A preservação da identidade cultural do país. Assim se faz a crítica armorial à sociedade industrial e à arte industrializada, 
como avalia Marco Aurélio Barbosa, em um artigo publicado no Jornal Opinião, de 26 de dezembro de 1976:

entre cantigas de aboio (semelhantes aos cantochões gregorianos introduzidos na Península Ibérica) e criação e adaptação de instrumentos capazes de reproduzir a temática regional e seus sons característicos, o Nordeste viu crescer a mais direta e simples forma de comunicação já desenvolvida nestas terras, e que hoje se vê ameaçada pela intensificação de uma outra cultura, levada pela TV. (BARBOSA apud DIDIER, 2000, p. 61).

Paralelamente a essas questões, em críticas às considerações da arte "pop" como a "verdadeira" arte popular, Antônio Nóbrega exemplifica o que ele caracteriza como um "mau serviço" ao processo de criação.

Aquela batida que a bateria faz nos computadores teve um papel de homogeneizar a música mundial. Esse tal de 'world music' não é mais do que a colocação dessa batida em todos os segmentos da música no mundo com esse nome de 'pop'. Um exemplo disso é a música africana. Mas bem entendido, a música realmente do povo da África, quando eles tocam naqueles instrumentos bem simples, quando fazem certas configurações de timbres, de rítmica... aquilo é que é música de vanguarda. De repente é desfigurado, porque chega lá a música americana, que chega em todo lugar, e diz que tem que se colocar esse ritmo porque isso é que dá dinheiro, isso é que dá notoriedade e as pessoas com menos consciência aceitam. (informação verbal) ${ }^{9}$.

9 Entrevista com o músico Antonio Carlos Nóbrega, cf. nota 6. 
A questão apresentada por Nóbrega remete a uma outra análise: o povo, enquanto destituído de consciência para discernir o conteúdo que lhe é apresentado, é vinculado à ingenuidade e incapacidade de optar por aquilo que lhe é imposto. Isso, é claro, tendo como pano de fundo todo um sentido econômico por trás dessa falta de resistência para com as imposições do mercado.

O personagem Tonheta de Antonio Carlos Nóbrega também foi alvo de duras críticas por parte do sociólogo pernambucano Sebastião Vila Nova, que avalia Tonheta como representante de uma "estética imoral", por fazer do povo necessitado do Nordeste objeto de riso. A avaliação de Vila Nova não diz respeito tão-somente ao personagem Tonheta, mas também "à visão senhorial de mundo que Ariano Suassuna impõe à cultura e à sociedade brasileira através de seu Movimento Armorial que reverbera na criação de Antônio Carlos Nóbrega" (CADENGUE, 1999, p. 55).

Como foi visto no primeiro capítulo, o personagem Tonheta segue, na música e no teatro, o perfil característico dos personagens pícaros, próprios do gênero picaresco do romance. Tonheta, João Grilo, Cancão de Fogo, Pedro Quengo, Benedito, Mateus e Bastião, para citar apenas alguns, representam uma estética que reflete um gênero literário e trazem na composição do personagem características próprias, como, por exemplo, a crítica a um determinado sistema social, cumprindo assim com uma das características mais marcantes dos pícaros, ou seja, as dificuldades e problemas são justificativas para suas atitudes de esperteza como forma de alcançar melhores posições na sociedade, mas não deixam de ser uma crítica ao sistema social vigente de uma sociedade que, até certo ponto, alija o direito de muitos terem acesso aos mesmos bens e possibilidades igualitárias de vida. Nesse sentido, Vila Nova deixa de levar em consideração a proposta de um tipo de narrativa que tem características próprias e fala de uma "estética imoral", mostrando desconhecimento quanto à estética desse gênero literário. 
Nessa mesma perspectiva, o jornalista recifense e crítico de cinema, Celso Marconi, teceu algumas críticas a Suassuna pelo fato deste ter cedido a peça "O Auto da Compadecida" a uma adaptação ao cinema pelas mãos do diretor húngaro George Jonas, depois de impedir, no ano de 1972, que o grupo de teatro da Universidade Católica de Pernambuco (TUCAP) continuasse se apresentando com a peça Torturas de Um Coração10 por ter dado uma roupagem "tropicalista" (TELES, 2000, p. 129). A esse respeito, a montagem do TUCAP foi apresentada no IV Festival Nacional de Teatro Amador, em São José do Rio Preto, São Paulo. O autor, a pedido dos diretores do grupo da Universidade, atendeu a dispensa do pagamento dos direitos autorais, mas não foi informado que linha o grupo pretendia dar ao espetáculo. Recebendo um tratamento que discordava do universo suassuniano, a montagem foi proibida de ser apresentada e teve grande repercussão nos jornais da época, como por exemplo, o Jornal do Brasil (2 de agosto de 1972) e O Globo (13 de agosto de 1972).

Para Marconi, "dentro do seu cristianismo sertanejo", Suassuna não pretende se aprofundar na realidade do povo nordestino, interessando-se tão-somente pela associação do sertanejo à piada, esquecendo-se, assim, da profundidade crítica que circunda a realidade nordestina.

Em resposta às críticas de Celso Marconi, num artigo que circulou no Diário de Pernambuco no dia 15 de junho de 1968, Suassuna comentou que o povo não aceitava as abordagens frias, vazias e artificiais realizadas pelos adeptos do Cinema

10 Primeira peça cômica para mamulengo escrita por Suassuna em 1951 que, segundo ele, representa a guinada da sua carreira, já que ela teria aberto o caminho para o Auto da Compadecida, pois até então ele só tinha escrito tragédia. 
Novo, no que diz respeito ao Sertão nordestino. Assim, Suassuna se mostra contra esse tipo de abordagem e questiona Marconi, respondendo às suas críticas:

segundo ele, nós nos recusamos a mostrar a realidade nordestina. Eu gostaria muito de saber qual é essa realidade nordestina que Celso Marconi pretende conhecer. Para ficar num caso que me toca mais de perto, uma coisa eu garanto: o único Sertão que Celso Marconi conhece é o que ele viu no cinema Art-Palácio, devidamente enlatado, desvirilizado e falsificado pelos cineastas de sua preferência. (SUASSUNA apud DIDIER, 2000, p. 59).

Em outro artigo do Diário de Pernambuco que circulou dois meses antes, no dia 14 de abril de 1968, Suassuna, de forma bastante irônica, questiona a capacidade intelectual do ex-aluno ${ }^{11}$. Com o título de "Resposta a Celso Marconi", Suassuna abria seu artigo da seguinte forma:

Celso Marconi foi meu aluno de estética na Faculdade de Filosofia, escola onde revelou a dose de inteligência exatamente necessária para ser aprovado por um professor conhecido entre os alunos por sua excessiva benevolência. Assim não foi por desprezo a ele que não respondi até agora a seus sucessivos ataques ao filme A Compadecida: foi, primeiro, por não ter entendido como é que um crítico já pode

11 Assim como Jomard Muniz de Britto, Celso Marconi cursou a cadeira de Estética na Faculdade de Filosofia, tendo Ariano Suassuna como professor. 
considerar ruim um filme que ainda não foi feito. O segundo motivo é que se é muito fácil revidar qualquer adversário que tem muitas idéias, é muito difícil objetar qualquer coisa a quem não tem nenhuma. (SUASSUNA apud TELES, 2000, p. 129).

As discussões se estenderam com Marconi chegando a escrever um outro artigo em resposta a Suassuna no Jornal do Commercio, em 29 de maio de 1968, chamado Respostas a um Professor de Bestética. No artigo, o adepto do Cinema Novo rebatia parágrafo a parágrafo declarações de Suassuna, inclusive na sua explicação sobre a adaptação d'A Compadecida pelo diretor húngaro, que já teria sido oferecida à direção de Joaquim Pedro de Andrade, que não aceitou a proposta, por falta de condições. A esse respeito, Marconi afirma ter sido cortesia do autor, já que, para ele, nenhum autor, participante do Cinema Novo, filmaria o Auto da Compadecida (TELES, 2000, p. 130).

Suassuna evitaria responder às críticas, preferindo, segundo entrevista de Muniz de Britto ao Jornal da Cidade, em 1981, outro tipo de prática: "Celso estava com livros e discos sentado no TPN quando sai o Ariano e dá dois murros nele e diz: 'Esse é pra você e esse outro é pra Jomard"' (BRITTO apud TELES, 2000, p. 130).

Através dessas discussões, Suassuna deixa claro sua discordância face às abordagens feitas pelos adeptos do "novo" e do tratamento dado por eles ao Sertão nordestino, "região imune às influências externas e rica em costumes antigos decantados, representativo de caráter nacional" (DIDIER, 2000, p. 61). Essas abordagens "frias", que fogem à realidade da região e dos seus elementos são exemplificadas por Suassuna em suas palestras e discursos, como na entrevista à Revista Caros Amigos (2003, p. 38-39), quando, falando sobre o tratamento dado aos 
personagens nordestinos pela televisão, mais especificamente a um filme de Lampião e Maria Bonita, ele comenta:

Rapaz, aquilo é um desastre! Disseram: 'Ariano, corra que vai passar um seriado de Lampião'. Quando vem o primeiro diálogo, eu digo: 'Fecha isso, desliga!' Chegava um gringo - porque, depois que Vargas Llosa botou um gringo no sertão, ficou moda, não é? Aí chegava um gringo no carro, Lampião mandava o carro parar e dizia: 'Se você não fizer o que eu tô mandando... (imita o sotaque), taco-lhe uma braçada de facheiro e toco fogo nesse tumóvel!' Tumóvel! Repare, eu nunca vi isso na minha vida, alguém chamar automóvel de tumóvel! Rapaz, e o clichê, além do mais errado, porque Lampião dizer que ia pegar uma braçada de facheiro... se você pegar uma braçada assim, até na sua alma fica! Você tem que tirar da alma com pinça, sabe? São uns falsificadores. Quer dizer, é contra isso que me bato. [...] Contra o pastiche, a falsificação, o grotesco, a caricatura baseada no pitoresco. Quando Luís Fernando de Carvalho foi fazer A Mulher Vestida de Sol, ele disse: 'Ariano, e a fala?' Eu disse: 'Olhe, você diga aos atores que façam a fala normal deles, o que eu não quero é miado nem chiado, faça uma fala normal'. E o resultado deu certo demais. Tinha uma atriz gaúcha, tinha atores de São Paulo, do Rio, de Minas, e ninguém nem notou, está certo? Revista Caros Amigos (2003, p. 38-39) 
Uma outra discussão seria levantada por Mário Vargas Llosa a respeito da identidade cultural proposta pelo Movimento Armorial que, para ele, seria "na melhor das hipóteses, uma ficção. E, na pior, uma prisão da qual convém escapar o quanto antes se se quer um homem livre e contemporâneo" (Vargas Llosa apud Cadengue, 1999, p. 57). A indagação levantada referese, também, a Nóbrega como possível refém de sua máscara (nesse caso Tonheta). Máscara essa que, segundo ele, uma vez colocada à face, refletirá apenas o vazio de si mesma.

Um homem "livre" e "contemporâneo", imerso e disperso nas tendências mercadológicas passageiras para melhor expressar o pensamento de Vargas Llosa. Ser esse homem, na maioria das vezes, significaria abrir mão da valorização de elementos próprios de uma cultura, frente ao processo de descaracterização próprio do consumismo global, que produz e reproduz "identidades partilhadas" (Hall, 2005, p. 74), através de produtos, bens, serviços, imagens e, sobretudo, mensagens. 
Capítulo 3

Acordes e textos armoriais 



\section{Acordes Armoriais: uma análise instrumental}

A entrada de Antonio Carlos Nóbrega no Movimento Armorial deu-se, como foi visto anteriormente, a partir do Quinteto Armorial. Foi a partir daí que sua vida artística tomou um outro rumo, passando a conhecer mais de perto um outro mundo, até então não apresentado de forma plena. Com o passar dos anos, o artista foi incorporando e conhecendo a música dos violeiros e dos tocadores de pífanos, a poesia e o canto dos cantadores, emboladores e romanceiros, a dança e a representação dos diversos brincantes, artistas ocultos do cavalo-marinho, passistas de frevo, puxantes da conhecida dança guerreira nordestina, os chamados caboclinhos, o sagrado e o profano dos pastoris, entre outros diversos elementos que permeiam a cultura popular brasileira.

É nessa direção que seu trabalho foi pautado, incorporando esses diversos elementos que passam a ser latentes dentro do seu trabalho. A partir desses aspectos, fizemos um levantamento de um dos elementos identificadores dos estilos, nesse caso específico, a análise instrumental dos discos Na Pancada do Ganzá, Madeira que cupim não rói (Na Pancada do Ganzá II), Pernambuco Falando Para o Mundo, O Marco do Meio-Dia e o Lunário Perpétuo. Ao todo, um total de 78 músicas, entre frevos, marchas, maracatus, cocos, xotes, choros, caboclinhos, cirandas, polcas, maxixes, entre outros ritmos. 
Esses discos refletem a influência do Armorial na proposta musical do artista, visto que, foi a partir daí, que se desenhou um trabalho solidificado inteiramente $\operatorname{seu}^{1}$, no que se refere à música, apreendido ao longo dos anos de convívio direto com outros artistas que procuravam, cada um na sua área de atuação artística, consolidar a estética preconizada por Ariano Suassuna.

$\mathrm{Na}$ análise instrumental, foi observada a configuração instrumental presente nos trabalhos recitais do artista a partir da organologia, como foi dito anteriormente. Utilizamos as seguintes categorias: metais (aerofones), cordas (cordofones), percussão (idiofones de altura indefinida); e madeiras (aerofones). Lembramos que os aerofones dizem respeito àqueles instrumentos que têm seus sons extraídos através do ar; cordofones, sons retirados através de cordas; e idiofones de altura indefinida, que são os instrumentos percussivos. Estabelecemos quatro categorias a partir de três formas de classificação dos tipos de sons, tendo em vista que os metais e as madeiras fazem parte do grupo dos aerofones. A partir daí, foi verificada a utilização desses instrumentos dentro da execução de cada uma das músicas.

Ao lançarmos um olhar mais específico sobre esses elementos, observamos uma relativa mistura na utilização de instrumentos que fazem parte do contexto mais erudito, assim como instrumentos vinculados ao popular. Dentro da categoria dos aerofones, por exemplo, foi verificada uma participação efetiva das madeiras, com destaque para a presença da flauta e flautim, com um percentual de $62,8 \%$ de participação na

1 Anteriormente, Antonio Carlos Nóbrega teve, no Quinteto Armorial ,sua experiência maior na música. Com o grupo, o artista participou da produção dos discos Do romance ao galope nordestino, de 1974; Aralume, no ano de 1976; Quinteto Armorial, no ano de 1976; e Sete Flechas, em 1980. 
harmonia das músicas, além do acordeom, utilizado em 61,5\% das músicas, seguido pelo saxofone, com 43,6\%; e pela clarineta, com $28,2 \%$. Já entre os metais, foi verificada a presença do trombone em 26 músicas, um percentual de 33,3\%. O trompete está presente em 23 músicas, formando um percentual de 29,5\%; e, em seguida, vem o bombardino com uma participação de 23,1\% no conjunto das músicas.

Já na categoria dos cordofones, verificou-se a presença marcante do cavaquinho, presente em 40 músicas, o que representa $51,3 \%$ de participação nas músicas dos cinco discos do artista. A rabeca vem logo em seguida com um percentual de 48,7\% das músicas. A partir daí, segue o bandolim com $25,6 \%$; a viola com $24,3 \%$ e o violão de sete cordas com $23,1 \%$. Já o violão está presente em 17 músicas, um percentual de $21,8 \%$; enquanto o violoncelo em $14,1 \%$ das músicas.

No que se refere à categoria dos idiofones de altura indefinida, foi verificada a presença marcante do pandeiro e da caixa em $57,7 \%$ das músicas, ou seja, presente em 45 músicas da discografia do artista cada um dos instrumentos. Em seguida, vem a zabumba, com um percentual de 53,8\%. Já o ganzá está presente em $28,2 \%$ das músicas, seguido pelo tambor de maracatu, com $20,5 \%$; o agogô e os pratos, com $16,6 \%$ cada; e o triângulo, com uma participação em 14,1\% nas músicas do artista.

Verificamos, nessa rápida distribuição dos números obtidos na análise, a forte presença de instrumentos de origem popular, como a rabeca, o cavaquinho, a zabumba, o pandeiro e a viola. Instrumentos que se enquadram naquilo que Ariano Suassuna vislumbrava em sua proposta para a música armorial. Ao lado desses instrumentos, verificamos, também, a presença do acordeom, que junto aos romances, excelências e loas, representa a influência ibérica do passado a que o criador do Movimento Armorial tanto se reportava. Assim como outras experiências 
armoriais em torno da música, como foi o caso do Quinteto Armorial, da Orquestra Armorial de Câmara e da Orquestra Romançal Brasileira, Nóbrega faz uso de instrumentos mais característicos da cultura popular, não deixando de fazer uso dos eruditos.

Ao adotar essa postura, Nóbrega vai muito além do uso de instrumentos. Sua performance, reunindo poesia, dramatização, dança, cenografia, música e, sobretudo, sua caracterização em palco, possibilita uma maior identificação por parte do público, que se reconhece nas diversas possibilidades apresentadas pela versatilidade do artista, que trabalha com elementos diversos da cultura popular, todos reunidos dentro de um único ambiente. Um trabalho repleto, presente na memória coletiva dos diversos públicos, que só pode existir enquanto uma prática vivenciada no cotidiano das pessoas, que celebram "sua revificação, e o mecanismo de conservação do grupo está associado à preservação da memória" (ORTIZ, 1994, p. 133).

Assim como faz referência o Movimento Armorial, Nóbrega mantém uma base com a origem ibérica e a arte popular nordestina, ressaltados como suportes para a "cultura nacional", que busca refletir a cultura autêntica formada na base popular da cultura nordestina, sem nenhuma influência estranha a nossa cultura. Em relação a isso, Suassuna se colocava considerando que essa questão da influência estranha à nossa cultura referese àquela que não faz parte da formação do povo brasileiro, não se estendendo, portanto, à influência ibérica.

Para melhor compreender a realização da análise instrumental adotada no presente estudo, vejamos a seguir um exemplo que ilustra os procedimentos utilizados de forma mais específica na análise instrumental da discografia de Antonio Carlos Nóbrega. 


\section{0 erudito e o popular no $1^{0}$ Movimento do Concerto para Dois Violinos em Ré menor}

Para efeito de apresentação dos procedimentos utilizados na análise instrumental, tomamos o $1^{\circ}$ Movimento do Concerto para Dois Violinos em Ré menor, de Johann Sebastian Bach, a partir de duas versões da peça, sendo a primeira executada por uma orquestra sinfônica estrangeira que caracteriza os elementos eruditos; e a segunda caracterizando o popular, executada pelo músico Antonio Carlos Nóbrega, adaptada para flauta e rabeca, também em ré menor, presente em um dos trabalhos recitais do artista, o disco Na Pancada do Ganzá.

Para essa parte específica da análise, foi levado em consideração, também, um procedimento de análise através de um metrônomo, com o objetivo de verificar a diferença de elaboração no conjunto das obras, quando foi observada uma total diferença na estrutura e na velocidade das duas versões, já que na primeira se mantém uma estrutura rígida e a segunda é executada em três momentos distintos, como será verificado mais à frente.

$\mathrm{Na}$ análise para identificação do erudito, feita a partir da versão orquestrada, levaram-se em conta as características do período Barroco na música, que vai de 1600 a 1750, quando Bach produziu a peça. É nesse período que a música instrumental passa a ter, pela primeira vez, a mesma importância da música vocal.

Nessa versão, foi identificada a ausência de aerofones e idiofones, sendo utilizados apenas os instrumentos que têm seus sons extraídos através de cordas, classificados como cordofones. São eles: Violino, viola, violoncelo, contra-baixo e cravo. Isso deixa clara a questão relativa à presença marcante da família do violino que caracteriza um ponto de destaque dentro do Barroco. Essa família veio substituir a família das violas, tida 
como centro das orquestras até então. Nesse sentido, o violino passou a desempenhar um peso importante na composição da orquestra. A seção de cordas transformou-se no núcleo da orquestra barroca, mas conservando um teclado contínuo (cravo ou órgão), de modo a preencher a harmonia.

Um outro aspecto que predominou, nesse período, foi a presença do baixo contínuo ou baixo cifrado durante toda execução da música, ou seja, tudo que o compositor escrevia sob a melodia resumia-se a uma linha do baixo que deveria ser tocada por algum instrumento grave de corda, como o cello, por exemplo. Essa linha continuava durante toda a execução da peça. Tal característica permaneceu por todo o período Barroco, construindo a base da harmonia e da tessitura de praticamente todo o tipo de música desse período. o baixo contínuo ou baixo cifrado torna-se a base de quase toda a música barroca, fornecendo uma decidida linha de baixo que impulsiona a música para frente, do começo ao fim. Outro traço de destaque nas orquestras barrocas era a presença do órgão ou cravo contínuo, preenchendo a harmonia, enriquecendo a tessitura e, de fato, mantendo a unidade da orquestra. Uma outra forte característica da música orquestral barroca era o contraste:

O compositor barroco está freqüentemente contrastando brilhantes filetes de sons, como dois oboés ou dois trompetes, com um fundo de cordas. Ou pode contrastar 'blocos' sonoros de diferentes timbres - por exemplo, uma passagem para cordas, depois para sopros, e depois a combinação das duas seções. (BENNETT, 1986, p. 43).

Ou seja, como sair do nível forte para o nível piano, e depois fazer um retorno repentino ao forte. Nesse sentido, às vezes uma frase suave pode ser a repetição da precedente, forte, criando um efeito de eco. Principalmente nos concertos, esses efeitos 
de ecos podem ser mais bem verificados, quando se contrastam timbres instrumentais de poucos instrumentos contra muitos, e de sonoridades fortes e suaves.

Já na versão produzida pelo artista Antonio Carlos Nóbrega, verificou-se uma diversidade bem maior na instrumentação utilizada. Nela, estão presentes a flauta, o acordeom e o sax alto, na categoria aerofone; a rabeca, o bandolim, o cavaquinho e o violão de sete cordas, na categoria cordofone; e a caixa, o pandeiro e a zabumba, na classe dos idiofones de altura indefinida.

Existe aí a predominância de instrumentos de cunho popular na execução da peça, como é o caso da rabeca, pandeiro, zabumba, cavaquinho, violão e acordeom. Instrumentos que, independente da sua origem, estão ligados ao aspecto popular da nossa cultura e se tornam elementos próximos, servindo de referência.

Uma característica que merece destaque dentro da versão popular é quanto à alteração da estrutura básica da música, criando três ambientes diferentes. Inicialmente, uma marcharancho, para num segundo momento executar um chorinho e, por fim, um terceiro ambiente executado através de um frevo. Todos, ritmos que surgem no Brasil, num processo de criação em contextos populares da nossa sociedade:

Surgidos no fim do século XIX entre os núcleos de moradores nordestinos da zona portuária do Rio de Janeiro, ligados todos a uma origem rural (foram os baianos migrados para o Rio que tiveram a idéia de desfilar com ranchos no carnaval), os primeiros ranchos cariocas saíam cantando pelas ruas as marchas e loas do repertório tradicional do ciclo de festas folclóricas de dezembro. (TINHORÃO, 1986, p. 132). 
O segundo ritmo executado pelo artista é o chorinho, música de câmara que também tem suas origens no contexto popular da nossa cultura:

O aparecimento do choro, ainda não como gênero musical, mas como forma de tocar, pode ser situado por volta de 1870, e tem sua origem no estilo de interpretação que os músicos populares do Rio de Janeiro imprimiam à execução das polcas, que desde 1844 figuravam como o tipo de música de dança mais apaixonante introduzido no Brasil. [...] Os componentes dos conjuntos de chorões cariocas do fim do século XIX e do início do presente século eram, na sua quase totalidade, representantes da baixa classe média do Segundo Império e da República. (TINHORÃO, 1986, p. 103-105).

O terceiro e último momento da versão do artista Antonio Carlos Nógrega dá lugar a um outro ritmo que surge num processo de transformação, a partir de outros ritmos presentes, também, num contexto popular. Trata-se do frevo:

o frevo pernambucano figura, ao lado do maxixe carioca, entre as mais originais criações dos mestiços da baixa classe média urbana brasileira, no campo da música e da dança. [...] Criação de músicos brancos e mulatos, na sua maioria instrumentistas de bandas militares tocadores de marchas e dobrados, ou componentes de grupos especialistas em música de dança do fim do século XIX (polcas, tangos, quadrilhas e maxixes), o frevo fixou sua estrutura numa vertiginosa evolução 
da música das bandas de rua, de inícios da década de 1880 até os primeiros anos do século XX. Os estudiosos do frevo pernambucano, embora discordando em vários pontos quanto a pormenores de sua história, são unânimes em concordar que as origens do passo (nome atribuído às figurações improvisadas pelos dançarinos ao som da música) se prendem à presença de capoeiras nos desfiles das ruas mais famosas bandas de músicas militares do Recife da segunda metade do século XIX: a banda do $4^{\circ}$ Batalhão de Artilharia, chamado o Quarto, e a da Guarda Nacional, conhecida por Espanha. (TINHORÃO, 1986, p. 138).

Verificamos aí a utilização de três ritmos populares. Uma marcha-rancho, um chorinho e, por fim, um frevo. Ritmos que surgem em ambientes próprios das camadas mais populares da nossa sociedade.

Enquanto na versão erudita mantém-se a mesma estrutura da música do início ao fim, com uma velocidade de 96 batidas por minuto (BPM), a versão popular apresenta-se dividida em três momentos distintos, com variação entre eles, apresentando, respectivamente, 118 durante a marcha-rancho; 94 no chorinho; e 138 batidas por minuto, com o frevo. Verifica-se aí a versatilidade da obra popular, com uma variação de elementos que enriquecem ainda mais a obra original, já que a primeira versão mantém uma única estrutura na execução da música.

Além dos três momentos, a versão de Nóbrega apresenta, ainda, um outro elemento que merece atenção especial, que diz respeito à menção feita pelo artista ao choro Escadaria, utilizado como cadência na execução da música, o que se caracterizaria como mais um elemento que ressalta a versatilidade e a 
possibilidade de recriação do popular. Enquanto Bach, imerso no estilo barroco, em que todos os instrumentos dialogam cada qual com uma linha melódica diferente, Nóbrega se apropria dessa estrutura composicional contrapontística e insere um contexto mais popular à obra.

Encontramos aí um exemplo claro da proposta armorial de criação, a partir de obras anteriores, ou melhor dizendo, de recriação das artes. Ao trabalhar com a peça $1^{\circ}$ Movimento do Concerto para Dois Violinos em Ré menor, Nóbrega amplia as possibilidades da música, incorporando a ela outros elementos que tornam possíveis observações diferentes acerca da mesma. É o que acontece quando ele se utiliza de instrumentos ligados ao popular da nossa cultura, como a rabeca, pandeiro, zabumba, cavaquinho, violão e acordeom, possibilitando uma interpretação diferente, ou melhor dizendo, uma identificação maior. 0 mesmo acontece, também, quando ele modifica a estrutura da música, incorporando ritmos que surgem no contexto popular da nossa cultura, além do choro Escadaria, utilizado como cadência na execução da música, algo que seria impossível de se verificar na estrutura rígida da versão erudita.

Uma obra que passou por um processo de reescrição, reelaboração, possibilitando, junto a essas modificações, outras possíveis análises, mais próximas e mais representativas da cultura popular e, por extensão, da região Nordeste. Ao incorporar elementos mais próximos da nossa cultura, como os ritmos e instrumentos, nesse caso específico, no $1^{\circ}$ Movimento do Concerto para Dois Violinos em Ré menor, Nóbrega faz uma interconexão entre elementos e facilita a assimilação e identificação por parte do público, uma reelaboração de uma obra Barroca, a partir da concepção de recriação das artes. 


\title{
Textos Armoriais: as letras falam por si
}

Como podemos ver, toda a obra de Antonio Carlos Nóbrega reflete não apenas a sobrevivência, mas, também, a permanência do Armorial no fazer artístico contemporâneo, embora saibamos que não exista o espaço devido para divulgação de trabalhos artísticos dessa natureza. Essa forma de trabalho vai refletir diretamente no maior reconhecimento por parte do público, quanto à representatividade da arte Armorial.

Nas letras das suas músicas, vamos encontrar um forte apego a algumas das propostas centrais da estética do Movimento, como acontece com os aspectos temáticos, com núcleos narrativos extraídos diretamente do romanceiro, como é o caso da música Vinde, vinde, moços e velhos (presente em duas versões nos discos Na Pancada do Ganzá e Pernambuco Falando para o Mundo), chamamento que já existe há mais de um século, despertando paixões dos partidários dos cordões azul e encarnado do Pastoril, na eterna disputa entre os dois lados:

\author{
Vinde, vinde, \\ moços e velhos, \\ vinde todos apreciar. \\ Como isso é bom, \\ Como isso é belo. \\ Como isso é bom, \\ É bom demais. \\ Olhai, olhai, \\ Admirai. \\ Como isso é bom, \\ É bom demais.
}


Se no disco Pernambuco Falando para o Mundo, existe a saudação de boas vindas para a participação dos "moços" e "velhos" no Pastoril, nesse mesmo disco, encerrando o trabalho, existe também o momento do adeus com a canção Despedida, também extraída do domínio público, com a participação de Wilson Freire.

\author{
Às cinco horas da manhã, \\ quando vem rompendo a aurora, \\ os anjos cantam no céu, \\ e as pastorinhas vão embora. \\ Com saudades eu me retiro, \\ que eu não vim para ficar. \\ As moças são deliciosas, \\ belas e formosas, \\ lindas como as rosas. \\ Já falta pouco para o sol \\ vir nos braços da aurora, \\ vem pra ficar com vocês \\ para levar-nos embora. \\ Vivendo de palco em palco \\ entre chegadas e partidas \\ estamos nós outra vez, \\ na hora da despedida. \\ Nós, brincantes, nos retiramos \\ não viemos pra ficar. \\ A vida de um menestrel \\ é sem porto e ao léo, \\ sempre a caminhar.
}


O uso das formas poéticas do romanceiro popular nordestino, com a utilização de algumas de suas formas, seja do martelo agalopado, do galope à beira mar, do martelo gabinete, ou do simples repente, reflete, também, diretamente num outro princípio Armorial. São vários os exemplos nos trabalhos recitais de Nóbrega, a exemplo das músicas Meu Foguete Brasileiro, escrita na forma de Galope à Beira-mar (estrofes de onze sílabas, em dez versos, com rimas ABBAACCDDC), uma das formas mais trabalhadas pelos cantadores; e a música Carrossel do Destino, exemplo apresentado a seguir:

\author{
Deixo os versos que escrevi, \\ as cantigas que cantei, \\ cinco ou seis coisas que eu sei \\ e um milhão que eu esqueci. \\ Deixo este mundo daqui, \\ selva com lei de cassino; \\ vou renascer num menino, \\ num país além do mar... \\ Licença, que eu vou rodar \\ no carrossel do destino. \\ Enquanto eu puder viver \\ tudo o que o coração sente, \\ o tempo estará presente \\ passando sem resistir. \\ $\mathrm{Na}$ hora que eu for partir \\ para as nuvens do Divino, \\ que a viola seja o sino \\ tocando pra me guiar... \\ Licença, que eu vou rodar \\ no carrossel do destino.
}




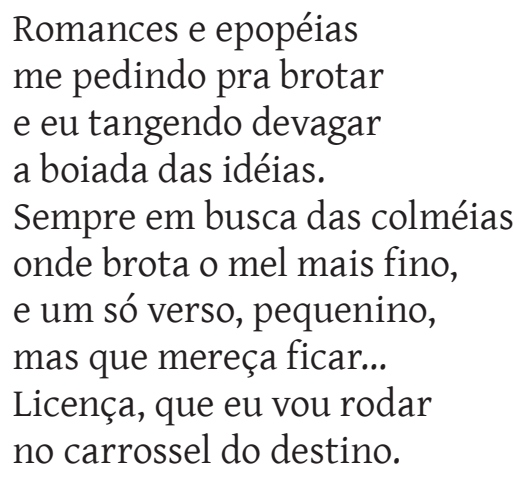

A música, de autoria de Antonio Carlos Nóbrega, em parceria com o escritor Braulio Tavares, vem escrita também em décimas de sete sílabas, ao ritmo de uma ciranda, com uma letra que trata da partida, do desprendimento, do tempo que passa e não mais volta. Fala, enfim, do que nos reserva o destino que, como um carrossel, não possibilita a ninguém saber em que ponto vai parar de girar. o carrossel do destino gira de forma diferente para cada um de nós. Cada qual com o seu tempo, cada tempo sem mais tempo para seguir.

Também numa parceria entre Nóbrega e Braulio Tavares, a música O Rei e o Palhaço, presente no disco Lunário Perpétuo, é mais um claro exemplo quanto ao uso das formas poéticas do romanceiro popular, com a utilização de algumas de suas formas tradicionais, na elaboração do trabalho poético do artista. Dessa vez, numa escrita em décimas de sete sílabas, forma utilizada tanto pelos cantadores, em seus repentes, quanto pelos mestres de Maracatu Rural ${ }^{2}$ em seus torneios poéticos.

2 Também chamado de Maracatu de Baque Solto, Maracatu de Orquestra ou, ainda, de Maracatu de Trombone, o Maracatu Rural, nomenclatura mais conhecida, tem origem incerta, com várias explicações para o seu surgimento, umas mais convincentes, outras mais fabulosas. Mas, todas as versões apontam para a mistura das culturas afro-indígenas como 
Sua coroa é de ouro, o meu chapéu é de palha.

A sua cota é de malha, o meu gibão é de couro.

Sua justiça é no foro, minha lei é o consenso. O seu reinado é imenso, minha casa é meu país. Você é preso ao que diz, eu digo tudo o que penso.

Você vem com a arma erguida, eu vou abaixando a guarda. Você vem vestindo a farda, eu de roupa colorida. Você disputa corrida, eu corro pra relaxar. Sua marcha é militar, a minha é de Carnaval. Seu traje é de general, eu visto pena e cocar.

Você liga a motosserra, eu planto flor no cerrado. Você só anda calçado, eu piso com o pé na terra. Você quer vencer a guerra, eu quero ganhar a paz. Você busca sempre mais, eu só quero o que é meu. Você se acha europeu, eu sou dos canaviais. 


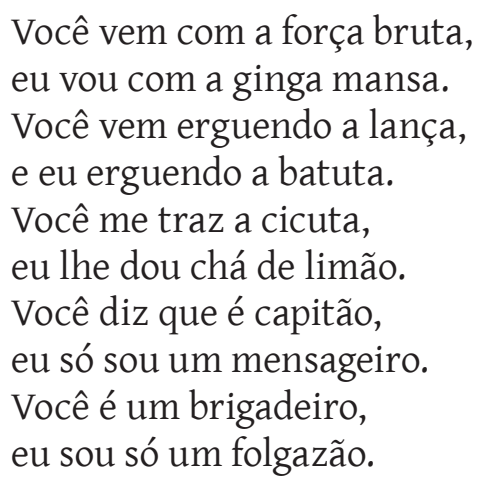

Ao som do Maracatu Rural nos é apresentado nessa música dois mundos bem diferentes. O mundo do "rei", com leis e regras a serem seguidas e obedecidas, antecedendo as conquistas pela força, guerra, poderio bélico, entre outros elementos. Tais aspectos vêm evidenciados, por exemplo, nas frases "você vem com a arma erguida", "você vem vestindo a farda", "você disputa a corrida", "você quer vencer a guerra", "você vem com a força bruta" e "você vem erguendo a lança", ou seja, um mundo de disputas e imposições aos menos favorecidos.

Ao "palhaço", representado aí pela grande parcela da população, os mais frágeis, são atribuídas qualidades vinculadas ao popular, como os próprios elementos expostos, a exemplo do chapéu de palha, do chá de limão, gibão de couro e o próprio festejo do carnaval. Ao longo do poema, o "palhaço" pode ser um homem do campo ou um trabalhador dos canaviais. Pode ser, ainda, um folgazão ou mesmo um índio, usando pena e cocar.

Perspectivas diversas podem ser apontadas ao longo da música, como, por exemplo, a própria lição de vida que é dada a cada resposta do "palhaço". Se o "rei" disputa a corrida, o "palhaço" corre para relaxar; se o "rei" liga a motosserra, o "palhaço" planta flor no cerrado; se o "rei" quer vencer a guerra, ao "palhaço" interessa ganhar a paz; e, por fim, se o "rei" ergue 
a lança, o "palhaço" ergue a batuta para reger uma orquestra sem desafinados, uma orquestra de alegrias e belos acordes que soa bem aos ouvidos dos tantos outros "palhaços" presentes na plateia de um único espetáculo.

A música 0 Rei e o Palhaço traz, ainda, uma outra perspectiva a ser observada em relação ao todo da produção de Antonio Carlos Nóbrega. A presença da temática reino é recorrente na sua produção, o que não deixa de ser, também, uma herança do romanceiro popular nordestino, já que essa temática encontra uma forte ligação com a tradição popular. "Nos folhetos de cordel, as fazendas são quase sempre reinos, e os fazendeiros são reis, condes, duques ou barões. Suas filhas são princesas, e os vaqueiros e cangaceiros são quase sempre os cavaleiros desses reinos imaginados pelos poetas populares" (NEWTON JÚNIOR, 1999, p. 210).

Como foi visto anteriormente, esse aspecto vem bem presente, também, na obra do criador do Movimento Armorial. É o caso dessa passagem no Romance d'A Pedra do Reino, quando Quaderna afirma sobre seu próprio reino:

Seria um Reino literário, poderoso e sertanejo, um Marco, uma Obra cheia de estradas empoeiradas, caatingas e tabuleiros espinhosos, serras e serrotes pedreguentos, cruzada por Vaqueiros e Cangaceiros, que disputavam belas mulheres, montados a cavalos e vestidos de armaduras de couro. Um Reino varrido a cada instante pelo sopro sangrento do infortuíto, dos amores desventurados, poéticos e sensuais, e, ao mesmo tempo, pelo risco violento e desembandeirado, pelo pipocar dos rifles estralando guerras, vinditas e emboscadas, ao tropel dos cascos de cavalo, tudo isso batido pelas duas ventanias guerreiras 
do Sertão: o cariri, vento frio e áspero das noites de serra, e o espinhara, o vento queimoso e abrasador das tardes incendiadas. (SUASSUNA, 2005, p. 115).

No trabalho de Nóbrega, a temática reino está presente em nove músicas que tratam direto ou indiretamente desse aspecto. Além da já citada O Rei e o Palhaço, são elas: Boi Castanho, O Romance de Clara Menina com D. Carlos de Alencar, Pernambuco Falando para o mundo, Quinto Império, Estrela D’Alva, Romance da Filha do Imperador do Brasil, Lunário Perpétuo e a música Excelência.

Juntamente ao uso dessas formas poéticas do romanceiro popular nordestino está a perspectiva Armorial de trabalhar com a recriação ou reelaboração de temáticas extraídas das manifestações populares do Nordeste, como já foi verificado em diversas ocasiões do presente estudo. Essa concepção também vem evidenciada de forma bastante significativa nos trabalhos de Antonio Carlos Nóbrega.

O caso do poema A Morte do Touro Mão de Pau é bem sugestivo para melhor identificarmos esses elementos. De autoria de Ariano Suassuna, inspirado no folheto O Boi Mão de Pau, do poeta rabequeiro rio-grandense-do-norte Fabião Hermenegildo Ferreira da Rocha (1848-1928), conhecido por Fabião das Queimadas, o poema foi posteriormente musicado por Nóbrega, no disco Lunário Perpétuo. Além de ter sua temática extraída do romanceiro, sendo escrita em sextilhas heptassilábicas de rimas simples, com a presença de rimas toantes, o poema foi reelaborado pelo escritor Ariano Suassuna, em memória de seu pai, João Suassuna.

A história trata de um boi brabo e da sua luta pela vida, numa fuga constante de vaqueiros que tentam, em vão, capturá-lo. Numa dessas perseguições, o Mão de Pau, para não ser apanhado e humilhado por vaqueiros, atira-se de um penhasco 
e se despede da vida de forma honrosa. O romance está implicitamente ligado aos momentos finais de vida do pai de Ariano Suassuna, João Suassuna, que apesar de não ter se suicidado como fez o Mão de Pau, vivenciou um conflito semelhante entre a possibilidade de desonra e da morte, e mesmo sabendo do risco que corria pelas ameaças que recebia, não hesitou em ir ao Rio de Janeiro para se defender na Câmara dos Deputados da acusação de cúmplice do assassinato de João Pessoa. No Romance do Boi da Mão de Pau, o boi-narrador cita vários nomes de vaqueiros que tentaram capturá-lo. Entre esses, um chamado Miguel e outro Antônio Rodrigues, mesmos nomes do assassino do seu pai e do contratante de sua morte, respectivamente.

$\mathrm{Na}$ versão do poeta popular, predomina o aspecto mais rural, com o Mão de Pau narrando suas 'escapadas' diante de vaqueiros que vinham de toda parte tentando capturá-lo. Apesar de sempre conseguir escapar, o Mão de Pau já demonstrava sua insatisfação com a necessidade de viver se escondendo e fugindo dos vaqueiros e seus cavalos, como podemos ver nesse trecho adiante:
$[\ldots]$
Me caçaram muito tempo,
ficaram desenganado
E eu agora de-meu,
lá na serra descansado.
Acabo de muito tempo
vi-me muito agoniado.
Quando foi com quatro mês, um droga dum caçadô, andando lá pulos matos, lá na serra me avistou, correu depressa pra casa dando parte a meu sinhô. 
Foi dizê a meu sinhô

- Eu vi Mão de Pau na serra.

Daí em diante os vaqueiro, pegaro a mi fazê guerra.

Eu não sei que hei de fazê para vivê nesta terra.

Na versão de Suassuna, o poema acentua seu tom mais trágico, com a narrativa em terceira pessoa, contada com maior riqueza de detalhes no que se refere ao aspecto físico do animal, que já não resiste às perseguições dos inúmeros vaqueiros que estão na busca de sua captura. Nessa versão, não existe relato algum da vida do animal, qualquer tipo de descrição de fatos de sua vida, que não seja a imediata perseguição pelos vaqueiros e seus cavalos. Vejamos a seguir o início dessa versão do poema:

Corre a Serra Joana Gomes

galope desesperado:

um touro se defendendo, homens querendo humilhá-lo, um touro com sua vida, os homens em seus Cavalos.

Cortava o gume das Pedras um bramido angustiado, se quebrava nas Catingas um Galope surdo e pardo e os Cascos pretos soavam nas pedras de Fogo alado, enquanto o clarim da Morte, ao Vento seco e queimado, na poeira avermelhada envolvia os velhos Cardos. 


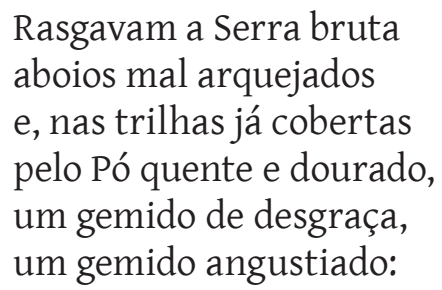

Ao contrário da versão original, quando existe um relato anterior acerca da vida e fama do Mão de Pau, Suassuna narra os momentos finais vividos pelo animal, quando numa dessas perseguições, não vendo mais saída, o Mão de Pau sobe a Serra Joana Gomes e de lá não sai mais com vida. A narrativa nesse momento ganha em carga dramática, uma vez que é nessa mesma Serra que ele nasce e é criado. A Serra Joana Gomes passa a ser testemunha ocular da tragédia que marca a vida do Mão de Pau desde o seu nascimento até os momentos finais da sua vida. Ali ele nasceu, viveu e não teve outra escolha que não fosse a escalada até um penhasco se jogando do alto. Um salto para a morte, justificado pela honra.

\author{
Num grito, todos pararam, \\ pelo horror paralisados, \\ pois sempre, ao rebanho, espanta \\ que um touro do nosso Gado \\ às teias da Fama-negra \\ prefira o gume do Fado. \\ E mal seus perseguidores \\ esbarravam seus Cavalos, \\ viram o Manco selvagem \\ saltar do Rochedo pardo:
}


-AAdeus, Lagoa dos Velhos!

Adeus, vazante do gado!

Adeus, Serra Joana Gomes

e cacimba do Salgado!

Assim vai-se o Touro manco,

morto mas não desonrado'!

O Mão de Pau não era um animal como os outros, fazendo com que mais vaqueiros viessem de longe com o objetivo de capturá-lo. À captura, o Mão de Pau preferiu a morte. Um desfecho trágico, mas honrado como afirma a versão de Suassuna. $\mathrm{Na}$ verdade, uma metáfora utilizada por Suassuna para falar do acontecimento histórico do dia 9 de outubro de 1930, data da morte de João Suassuna.

O processo de reelaboração da obra continua na música A Morte do Touro Mão de Pau. Nessa versão, Nóbrega alterna declamações com bandas-de-pífanos, cantoria-de-viola e aboios e proporciona um ritmo mais intenso, aumentando também a carga dramática em torno da perseguição que vai originar a morte do Mão de Pau. Temos aqui duas versões trabalhadas na perspectiva de recriação das artes, como propõe o Armorial, a partir do uso de formas poéticas do romanceiro popular. Merece destaque na versão musicada por Nóbrega o timbre de voz imposto pelo artista. Um elemento próprio dos cantadores que se caracteriza como mais um aspecto presente na tradição nordestina.

A ideia de elaboração de uma obra, a partir de trabalhos anteriores, pode vir de forma literal como foi verificado no poema A Morte do Touro Mão de Pau ou através de alguns elementos isolados dentro do contexto de uma determinada produção. É o caso do personagem Brusacã (uma das muitas formas assumidas pelo demônio) descrito por Ariano Suassuna no Folheto LVI do Romance d'A Pedra do Reino, intitulado A Visagem da Besta Brusacã. A recriação, a partir desse personagem, pode acontecer 
de forma literal, como é o caso da pintura Besta Bruzacã, de Miguel dos Santos; ou, ainda, a partir de um elemento específico dentro da obra. É o que acontece, por exemplo, na música Desassombrado, presente no disco Na Pancada do Ganzá, quando surge Bruzacã.

Na obra de Suassuna, Bruzacã surge a partir de uma descrição do personagem Quaderna para o Juiz Corregedor, depois de ser questionado sobre sua crença no diabo. Quaderna diz acreditar e descreve as características da Besta Bruzacã para o Juiz Corregedor, que afirma nunca tê-la visto:

[...] Pois eu me admiro muito, porque é a Besta mais horrorosa e conhecida por todo esse mundo velho aí afora! É coisa sabida, Sr. Corregedor: ela é o Mal, o Enigma, a Desordem! Passa no Mar os seis meses do tempo de chuva. Durante esse tempo, tem duas ocupações: causa as tempestades e fica esperando, perto da Costinha, aqui na Paraíba, a chegada das Baleias, que ela sangra e devora como se fossem traíras ou Curimatãs. Aí, quando vem chegando Setembro, ela sai do Mar, soprando fogo pelas ventas, e vem para uma Furna de pedra perdida no Sertão. O fogo soprado pela respiração dela é que faz a seca! E ela aparece com muitas formas! [...]. (SUASSUNA, 2005, p. 402).

Quaderna conta para o Juiz Corregedor a visagem do vaqueiro Manuel Inácio, que teria visto Bruzacã sair do mar, próximo à Praia de Touros, no Rio Grande do Norte, perto de meio-dia, no dia 24 de agosto de $1919^{3}$, quando viajava com um rebanho de

3 Esta data é na crença popular nordestina o dia em que o diabo anda solto pelo mundo, além de ser também o dia do nascimento do Boi 
gado que iria vender em Macau e alguns burros carregados de couros para trocar por sal para o Sertão. Segundo Quaderna, depois de parar para almoçar e descansar um pouco, enquanto os animais pastavam, Manuel Inácio observou que a terra se elevava suavemente formando um morro pedregoso que caía no mar. Deslumbrado com o fenômeno que estava por acontecer e sem saber do que se tratava, o vaqueiro começou a ouvir uns mugidos estranhos e poderosos e, de repente, via sair das profundas águas do mar a Bruzacã:

[...] Ah, só quem já viu Bruzacã é que pode imaginar como são poderosas e aterrorizantes as formas que ela toma! São sete Chifres turvos e amolados, o Focinho peludo, a Corcova cerúlea! No cabelouro espesso, uma Cabeleira de serpentes e conchas entrançadas! O olhar de Cobra e o corpo feito à semelhança de um corpo enorme de Touro branco! Era a Besta marinha, partejada pelos lombos diabólicos e sagrados do Mar! Seu olhar chamejava, ora amarelo, ora azul como um aço de Martelo! Ao fogo do sopro das suas Ventas, ferviam as águas em borbulhas de Enxofre envenenado. 0 peito era coberto pelo musgo nojento que suja e mancha as paredes do Inferno alumiado! As espáduas eram cobertas de malhas feridentas cor de ferrugem e em cada uma das suas ancas verdes luzia uma estrela amarela, brilhando entre sargaços e a salsugem, entre ostras pegadas ao tronco, anoso e velho como um velho Rochedo extraviado. (SUASSUNA, 2005, p. 406).

Mandingueiro. 


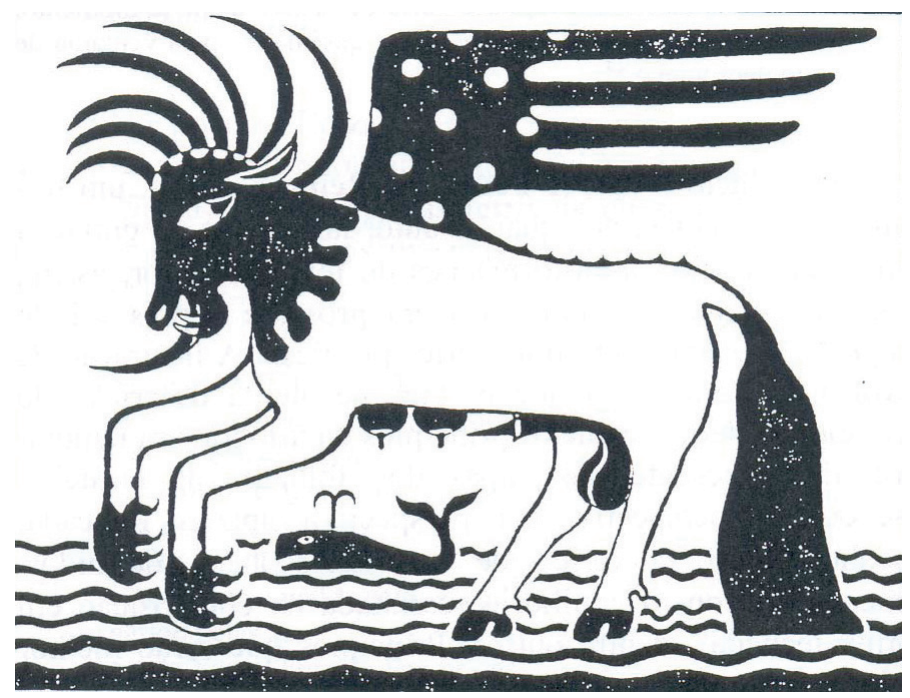

FIGURA 1 - Imagem da encarnação da Besta Bruzacã.

Vemos aí a descrição da assustadora e temida Bruzacã, uma das formas do demônio descritas na obra. Na música Desassombrado, ela surge de forma menos aterrorizante, porém não menos temida, por um personagem galopando no chitão de sua burra.

Desassombrado, eu desassombrei.

Eu pensei que o malassombro fosse maior do que eu.

Ói, meus senhores, vou contar minha odisséia:

viajei no pé da idéia prá tecer este cantar. 
E galopando

no chitão de minha burra

fiquei preso numa furna

sem poder mais cavalgar.

[...]

No outro dia,

a Brazucã me apareceu, minha alma estremeceu, eu fiquei pra me acabar.

Aí pensei:

me valei Nossa Senhora, não me leve nessa hora, ainda quero vadiar.

Ao ritmo de um xote, a música, de autoria de Nóbrega e musicada por Antônio Madureira, narra a história de um personagem que sai por aí viajando e desassombrando alguns "malassombros" e se depara com a Besta Brusacã, no resgate de um personagem presente numa outra obra Armorial, nesse caso específico 0 Romance d'A Pedra do Reino, fazendo dela apenas uma passagem dentro de uma outra obra, o que não deixa de se caracterizar como uma recriação.

Um outro aspecto presente nas letras das músicas de Antonio Carlos Nóbrega que vai tornar mais latente essa percepção do Armorial e seu reconhecimento, a partir do trabalho com elementos próprios da cultura popular, é o aspecto emblemático e simbólico. São casos em que as letras das músicas surgem como verdadeiras insígnias, repletas de elementos que transcendem o texto, com alusões a bandeiras, estandartes, agremiações dos blocos carnavalescos próprios dos períodos festivos dos contextos populares, entre outros diversos elementos que se fazem presentes. $\mathrm{Na}$ verdade, mundos distintos que se formam a 
partir da descrição textual, como podemos verificar na música Estrela D'Alva, presente no disco O Marco do Meio-Dia, de autoria de Nóbrega, em parceria com Braulio Tavares e Zezinho Pitoco:

\author{
Estrela d'Alva, \\ olha a luz do dia. \\ Estrela d'Alva, \\ olha a luz do sol. \\ Estrela d'Alva, \\ não me deixe sem meu guia. \\ Estrela d'Alva, \\ não me deixe só.
}

Caixa-de-guerra, maracá, porta-bandeira, rainha negra batendo palma de mão... Baque-virado fez tremer o chão do mundo, bomo-profundo ressoou trovão...

Ladeira acima os cortejos vão seguindo, Brasil afora vai cantando a procissão... Nos estandartes os emblemas do Divino, olhos na altura e os pés no chão.

Num mar de gente os andores navegando santos de barro e resplendores de papel, ramos e palmas verdejando a rua inteira, e a padroeira a flutuar no céu.

Anjos-meninos de olhos pretos e asas brancas, e a banda toca um hino triste e triunfal, cristãos e mouros cruzam lanças na avenida e se ajoelham frente à catedral. 
Cacos de vidro são rubis e diamantes, e cada crente nesse instante é um Jesus, cada promessa conta o drama de uma vida, e cada vida se transforma em luz.

Blocos desfilam seus calungas e brincantes, bichos gigantes, jaraguá, cobra-coral... Reis maltrapilhos vão cantando Ave Maria, e a romaria puxa o Carnaval.

Como podemos verificar, o aspecto emblemático reflete o aspecto visual da letra da música. De forma detalhada, a letra apresenta um grande cortejo, repleto de luz, cor e musicalidade que vai cortando o Brasil numa grande procissão. Na verdade, um momento de reunião entre diferentes cortejos, com maracatus, caboclinhos, chegança ${ }^{4}$, além da procissão. Todos os cortejos reunidos num único e maior momento, o carnaval, com as diversas raças e manifestações presentes e dividindo o mesmo espaço. Todos guiados pela Estrela D’Alva, guia de cada um dos "andores" no imenso "mar de gente".

Esse aspecto emblemático e simbólico que transpõe o texto pode ser verificado em outros diversos exemplos. Caso semelhante acontece com o poema Martelo D'O Marco do Meio-Dia, presente no disco 0 Marco do Meio-Dia:

4 A chegança é uma dança representativa das lutas entre cristãos e mouros no início da monarquia portuguesa. Na apresentação, formam-se dois partidos: o dos mouros, encastelados num forte construído na praia; e os cristãos, que ficam em canoas e jangadas. Depois de comunicações e discussões, os cristãos declaram guerra e os mouros saem do forte para a batalha simulada, que termina com a vitória dos cristãos, com os mouros refugiados no castelo, hasteando bandeiras brancas com a cruz vermelha da Ordem de Cristo. Ao final, o Rei Mouro é trazido à presença do Rei Cristão para ser batizado com água do mar, ao som de tambores, flautas, violas, maracás e cantos de vitórias. 


\begin{abstract}
A Bandeira do Sol estrala ao vento e soa a minha voz de Cantador, num protesto do Sonho contra a Dor, a pobreza do povo e o sofrimento. Nas estrelas do Canto, o pensamento ergue um Marco que é só anunciado. Nossa sorte de Povo injustiçado é vencida por nós ao som da luta, e, no meio do palco, o que se escuta é o sol da justiça do Sonhado.

Ao final desta Dança bela e forte sou eu o Cantador, dono da Casa, e, com versos de sangue, fogo e brasa, forjo o Marco e celebro a minha sorte. $\mathrm{Na}$ viola, eu vou batendo a Morte e assumindo a coroa de Guerreiro. Ao cantar meu país, sou o Lanceiro, olho o sangue ferido do meu povo e sonho, ao meio-dia, um Canto novo, levantando este Marco brasileiro.
\end{abstract}

De autoria de Ariano Suassuna e Antonio Carlos Nóbrega, o poema Martelo D’o Marco do Meio-Dia não é menos emblemático que o exemplo anterior. Uma descrição detalhada de um mundo que envolve sangue, fogo, brasa, brilho, sonhos, justiças, crenças e glórias de um reino que se junta ao aspecto simbólico presente no próprio texto. Duas linguagens distintas, a partir de um único elemento, mas que, reunidas, contemplam um ao outro.

Em determinado ponto, o texto poderia substituir a imagem e a imagem representar o próprio texto ou, ainda, um decifrando o outro, ampliando suas possibilidades. Essa perspectiva mais subjetiva aqui exposta poderia ser associada ao princípio da 
integração das artes que propõe o Armorial. Ou seja, nesse caso específico, ao criar um texto, o escritor lhe possibilitaria outras visões, trazendo novas perspectivas, a partir de uma primeira matriz. Uma espécie de leitura não-linear que poderia ter início num texto escrito, que se caracterizaria como a matriz inicial para em seguida, ter sequência através de uma leitura imagética, elaborada a partir da primeira e, assim, sucessivamente.

O princípio da integração entende a obra de arte pelo lado oposto. Os diversos gêneros de arte não só podem como devem se complementar, principalmente no campo das artes plásticas. Dessa forma, é perfeitamente legítima a preocupação de um escultor com a cor, ou a de um arquiteto com elementos de construção similares às cariátides gregas, que são escultura e estrutura ao mesmo tempo. (NEWTON JÚNIOR, 1999, p. 108).

Esse tipo de elaboração dos trabalhos Armoriais faz de cada obra um ponto de partida para as demais. Nesse sentido, esse princípio vai direcionar a produção das artes Armoriais para algo já mencionado e discutido amplamente ao longo desse trabalho, que diz respeito à criação, a partir de obras anteriores, enriquecendo e ampliando diferentes temas.

Como podemos verificar, esse processo é bastante presente notrabalho de Antonio Carlos Nóbrega e se faz presente, também, no seu repertório, na utilização de alguns romances de origem ibérica. Assim como o Quinteto Armorial, Nóbrega, ao longo dos seus trabalhos recitais, faz uso de alguns desses romances e loas, imprimindo não apenas o cantar, mas a interpretação dos personagens envolvidos na história. Essa sua habilidade exímia possibilita uma proximidade, uma linha tênue entre seu trabalho e o reconhecimento por parte do público. 
$\mathrm{Na}$ verdade, o ato de cantar poemas memorizados é privilégio não apenas de cantadores profissionais, mas também de pessoas, na maioria das vezes, idosas, que guardam em sua memória longos poemas, os quais recebem o nome de cantigas velhas. É o que diz o escritor Braulio Tavares ao citar o exemplo do Romance de Dona Silvana, presente parcialmente no Romance d'A Pedra do Reino.

'Romanceiras' ou 'cantadeiras' como Donana existem em grande número ainda hoje, trazendo na memória dezenas de romances obscuros, alguns deles com séculos de existência, passados de geração em geração, de voz em voz, de memória em memória. São o fluxo ainda vivo de uma cultura oral em que essas histórias são contadas e recontadas muitas vezes, perpetuando-se. Na passagem de uma pessoa para outra o texto sofre perdas, alterações, acréscimos, mas a natureza peculiar dessa literatura faz com que tais modificações não sejam vistas como erros, mas como variantes. No universo dos romances orais não existe uma versão correta e versões erradas. $O$ romance é a soma conjunta de todas as suas versões. (TAVARES, 2007, p. 30).

Como foi visto no primeiro capítulo, tal aspecto é possibilitado pela memória, aspecto importante da narrativa e elemento bastante presente na elaboração das artes populares, constituindo-se na formação de uma identidade social, que influencia diretamente nas interpretações apresentadas, a partir dos grupos e pensamentos a eles pertencentes, nos quais os indivíduos estão inseridos. 
Enquanto representação, a Memória permite que se possa lembrar sem a presença de coisa ou de pessoa evocada, simplesmente com a presença de uma imagem no espírito e com o registro de uma ausência dada pela passagem do tempo. [...] O final desse processo de rememoração seria dado pelo reconhecimento, por aquele que rememora, da certeza do acontecido: foi ele, foi lá, foi então, foi assim. O reconhecimento se opera por um ato de confiança, que confere veracidade à rememoração. (PESAVENTO, 2003, p. 94-95).

Nos trabalhos recitais de Antonio Carlos Nóbrega, identificamos alguns casos, a exemplo dos títulos Minervina, o Romance de Clara Menina com D. Carlos de Alencar, Romance da Nau Catarineta e o Romance da Filha do Imperador do Brasil. Todos esses, assim como outros tantos exemplos dentro do trabalho do artista, passaram por esse processo de apropriação, cabendo à memória a manutenção dessas características que embora preservadas e, portanto, vivas, mantêm-se no anonimato.

No caso da música Minervina, de autoria de Nóbrega, em parceria com Marcelo Varella, presente nos discos Na Pancada do Ganzá e Pernambuco Falando Para o Mundo, trata-se de uma versão do romance de mesmo nome, de origem ibérica, que veio para o Brasil no século XVII e que ainda é encontrado na região nordestina. Sua letra faz menção à personagem Minervina, que é apresentada como fêmea fogosa, dona de um voraz apetite sexual.

Quem nunca viu amor assim tão roxo... vai fazer fuxico quando ver Minervina. Desvergonhada, não conhece alvoroço, na hora $\mathrm{H}$ é minha estrela matutina. 


\author{
É minzinguenta quando vai prá brincadeira. \\ Não dá bandeira na hora da cavilação. \\ É majestosa, topa tudo a noite inteira, \\ Quando me arrocha faz das tripas coração. \\ Ô Minervina! Ô Minervina! \\ Rebola-bola no consolo \\ das meninas.
}

Os títulos Romance da Nau Catarineta e Romance da Filha do Imperador do Brasil, ambos presentes no disco Lunário Perpétuo, estão presentes no Romance d'A Pedra do Reino e o príncipe do sangue do vai-e-volta, e seguem a proposta Armorial de recriação a partir de obras anteriores. Nas duas músicas, Nóbrega representa diversos personagens, atribuindo-lhes vozes peculiares.

Na versão presente no Romance d'A Pedra do Reino e o príncipe do sangue do vai-e-volta, o Romance da Nau Catarineta aparece no folheto XXXIV, intitulado Marítima Odisséia de um Fidalgo Brasileiro, num diálogo entre Quaderna, Samuel e Clemente. Incentivado pelas ideias de Quaderna, Samuel começa a relatar vários trechos da crônica seiscentista de Frei Vicente do Salvador sobre Duarte de Albuquerque Coelho e Jorge de Albuquerque Coelho, filhos de Duarte Coelho.

Em um dado momento, Samuel fala de uma nau brasileira, sob o comando de Jorge de Albuquerque Coelho, que já estaria sem nenhum tipo de mantimento, pois os franceses teriam deixado apenas "dois sacos de biscoitos podres, "uma pouca de cerveja danada', duas canadas de vinho, um frasco de água-deflor, alguns cocos, poucos punhados de farinha e seis tassalhos de peixe-boi" (SUASSUNA, 2005, p. 218). Por mais que Jorge de Albuquerque tivesse o cuidado de dividir bem a pouca comida restante entre os tripulantes, com o passar do tempo, a marujada começou a ficar faminta, chegando ao desespero de "deitar 
sortes", para escolher um dos homens da nau a ser morto, servindo de comida para os outros tripulantes. Nesse momento, o personagem protagonista Quaderna associa a história contada por Samuel à História da Nau Catarinet ${ }^{5}$, romance de origem ibérica, cantado no Sertão nordestino, fazendo parte do Fandango, uma tradicional dança em pares presente no Nordeste brasileiro, originada em Portugal e Espanha.

O tradicional romance é apresentado por Nóbrega como fandango ou marujada ${ }^{6}$. Com suas toadas populares, as melodias presentes no disco são as mesmas que foram utilizadas por Antônio José Madureira, numa versão instrumental escrita para o Quinteto Armorial.

Nessa versão, Nóbrega mantém o diálogo constante entre o Capitão-General e o Gajeiro durante quase toda a execução da música. Ao final, surge um terceiro personagem, o demônio. Cada um dos personagens recebe um tratamento diferenciado por Nóbrega, que incorpora características para cada um deles, através da sua interpretação.

5 A História da Nau Catarineta narra a história de uma nau que há mais de um ano vagava pelo mar. Já não tendo mantimentos, a tripulação "deita sorte" a uns dos companheiros de bordo para que servisse de alimento, que acabaria sendo o Capitão-General. Não querendo se entregar, o Capitão-General insiste na possibilidade de salvação, pedindo ao Gajeiro que suba até o mastro real para ver "terras de Espanha e areias de Portugal". Depois de prometer o que podia em troca da vida, o CapitãoGeneral descobre que ali estava o Diabo, tentando a tripulação, e a única coisa que o interessava era a alma do Capitão. Não aceitando se entregar ao Demônio, o Capitão se joga ao mar, mas um anjo o toma nos braços, salvando sua vida e a tripulação que consegue chegar ao Porto do Mar.

6 Trata-se de uma simulação de combate naval inspirado na história da Nau Catarineta ou outra qualquer tragédia acontecida no mar. Os principais personagens são: Capitão-General, Capitão, Piloto, Imediato, Médico, Mestre, Contra-Mestre, vinte e quatro marujos, Gageiro e Calafate. 
O mesmo acontece com o Romance da Filha do Imperador do Brasil. Recriado por Ariano Suassuna, o romance se passa num contexto sertanejo, tendo como personagens o Imperador Dom Pedro, a Infanta, a Criada e o Vaqueiro. Cada um desses personagens recebe um tratamento diferenciado na versão musicada por Nóbrega, que explora suas qualidades ao som de um xote, com as presenças marcantes do acordeom, triângulo, zabumba, pandeiro e violão. Dessa forma, atribui vozes características para cada personagem, com destaque para o tom debochado em falsete, utilizado para interpretar a voz da Infanta, de modo zombeteiro.

A história narra uma situação vivida pela Infanta, filha do Imperador Dom Pedro, que se apaixona por um Vaqueiro:
O Imperador Dom Pedro
tem uma Filha bastarda, a quem quer tanto do bem
que ela ficou malcriada!
Queriam casar com ela
Barões de capa e de espada.
Ela, porém, orgulhosa,
a todos que recusava:
- Este, é menino! Esse é velho!
Aquele, lá, não tem barba!
O de cá, não tem bom pulso
Pra manejar uma Espada!
Dom Pedro falou, se rindo:
- Inda serás castigada!
Não vás tu, de algum Vaqueiro,
terminar apaixonada!

E mesmo com os cuidados e orientações do Imperador, a Infanta acaba se apaixonando por um Vaqueiro. $O$ fato acontece na madrugada, quando, da janela, ela observa passar três 
moradores que trabalhavam de enxada. Um deles, o que mais trabalhava, chama atenção da princesa que pede para a Criada levá-lo até ela.

$[. .$.

- Senhora, o que é que me manda?

Eu vim por vossa chamada!

- Quero saber se te atreves

a queimar minha Coivara!

- Atrever, me atrevo a tudo,

que um homem não se acovarda!

Dizei-me, porém, Senhora, onde está vossa Coivara!

- É abaixo dos dois Montes,

na Fonte das minhas águas,

abaixo do Tabuleiro

e na Furna da Pintada,

na linha da Perseguida,

no corte da Desejada!

Passam o dia folgando,

o mais da noite passavam,

e o Vaqueiro socavando:

ele sabe o que cavava!

À meia-noite, a Princesa

pediu tréguas, por cansada:

- Basta! Basta, meu Vaqueiro!

Queimaste mesmo a Coivara!

Não sei se por varas morro

ou com ela incendiada!

E, assim, a filha do Rei

do orgulho foi castigada! 
No Romance d'A Pedra do Reino, o Romance da Filh a do Imperador do Brasil surge depois de um diálogo entre o personagem Quaderna e seu padrinho João Melchíades. Inicialmente, o padrinho conta para Quaderna os tipos principais de romances versados. "[...] os romances de amor; os cangaceiros e cavalarianos; os de exemplo; os de espertezas, estradeirices e quengadas; os jornaleiros; os de profecia e assombração; e os de safadeza e putaria" (SUASSUNA, 2005, p. 94). Em seguida, ele conta o romance, que foi avaliado por Quaderna como sendo "uma espécie de mistura de romance de amor com romance de putaria".

Já O Romance de Clara Menina com D. Carlos de Alencar, que consta no disco Na Pancada do Ganzá, é uma das muitas versões ibéricas e brasileiras existentes, sendo, também, diversos os títulos. Na recriação musical, como informa o encarte do disco, Nóbrega interpreta os quatro personagens centrais da história: Clara Menina, o Caçador, o Dom Carlos de Alencar e o Rei.

Comparada a uma outra versão coletada por Pereira da Costa, intitulada Clara Linda, que consta no estudo Os Romances da Tradição Ibérica na Obra Midiática de Antonio Carlos Nóbrega, do pesquisador Roberto Benjamin, observa-se que são poucas as alterações entre uma e outra. A versão de Nóbrega explora a narrativa por um viés mais picaresco, algo mais explícito, mas não menos insinuante do que a outra versão, como podemos verificar em alguns trechos do poema.

\author{
Estava Clara Menina \\ com D. Carlos, a brincar, \\ nua da cintura prá cima, \\ nua da cintura prá baixo, \\ namoro pra se casar! \\ Mas passou um caçador \\ que não devia passar...
}




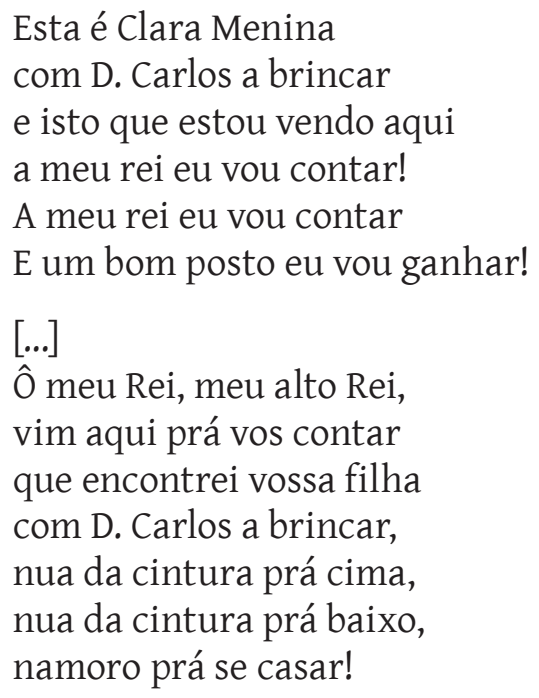

A situação é a mesma na versão a seguir, talvez explorada de maneira um pouco mais sublime, mas que não leva a uma outra interpretação que não seja a evidenciada anteriormente. Na versão coletada por Pereira da Costa, mudam os personagens, com D. Carlos de Alencar tornando-se Felizardo e, como o próprio título sugere, Clara Linda ao invés de Clara Menina.

Estava Clara Linda com Felizardo a brincar, debaixo de um arvoredo, num formoso roseiral; a um vassalo que passava, e todos os passos viu dar, Felizardo pediu logo que a el-rei não vá contar.<smiles>[CH]1CCC1</smiles>

Deus vos salve, senhor Rei, e vossa coroa real; 


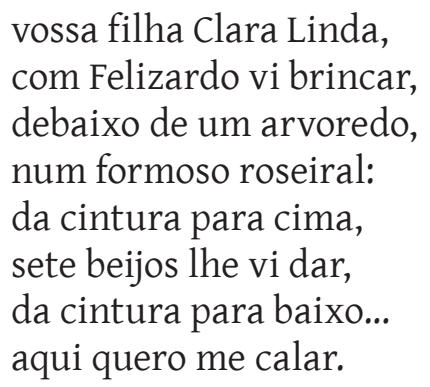

$\mathrm{Na}$ recriação musical, ao som de uma cantoria de viola, Antonio Nóbrega interpreta mais uma vez cada um dos personagens, acrescentando assim mais um elemento ao texto inicial. $\mathrm{Na}$ sua interpretação, ganha destaque a presença do personagem Tonheta, na figura do Caçador, com seu modo bem singular de se manifestar, provocando um ar de graça e trapalhada em meio à desgraça em que se mete, ao fazer a "fofoca" para o rei do namoro da sua filha com D. Carlos de Alencar:

Tu fizeste muito mal

em aqui isso contar, na frente de todo mundo, pra todo mundo escutar! Devias ter me chamado para um particular!

Eu estava só brincando quando disso vim falar! Não era Dona Clara menina nem D. Carlos de Alencar! Ela estava bem vestida, lá na igreja, a rezar!

Personagem brincante fixo de Antonio Carlos Nóbrega nos seus espetáculos, a mais recente aparição do Tonheta nos trabalhos recitais do artista foi no Lunário Perpétuo. Ele surge 
claramente na já citada canção Meu Foguete Brasileiro. Numa composição do poeta paraibano Braulio Tavares e música de Nóbrega, a obra narra as façanhas picarescas tonhetânicas a bordo de um foguete.

Eu fiz um foguete de andar pelo espaço, igual um que eu vi pela televisão: não sei se era coisa da França ou Japão, mas basta ver gringo fazer, eu já faço!... Mandei buscar logo cem chapas de aço, latão, alumínio, ferro de soldar; dez mil arrebites para reforçar a parte de fora da infra-estrutura: cem metros de longo, trinta de largura, e dez de galope voando no ar.

Botei no foguete diversas antenas para captar raios infravermelhos. Na parte de cima, um sistema de espelhos que amplia as imagens de estrelas pequenas. Motores na popa que servem apenas pra tudo aquecer, e pra refrigerar. Movidos a pura energia solar tem computadores, TVs virtuais: mil inteligências artificiais que cantam galope, voando no ar!

[...]

Depois de sentado no meu tamborete, puxei a lavanca, pisei no pedal, subi pro espaço com força total, fazendo tremer o motor do foguete. Passei bem por cima do Empire State, da torre eiffel, e do palomar; e vi pela tela se distanciar 
a mancha azulada do nosso planeta...

Pensei: 'Minha Nossa! Aqui vai Tonheta, cantando galope, e voando no ar!'.

[...]

Foi tanta Viagem, foi tanta Aventura, foi tanta Demanda, foi tanta Odisséia... eu posso jurar à distinta platéia que tudo isso foi a verdade mais pura. Também teve um pouco de literatura, história inventada para relaxar; mas eu que não minto não quero falar, e o resto eu só conto aqui pra você no próximo show, ou em outro CD, cantando galope e voando no ar...

Para poder realizar a viagem fantástica, o personagem Tonheta constrói um foguete "de mil inteligências artificiais", com recursos "ultra-modernos" para levar alguns produtos para exportação. Produtos populares de uso diversos, como, por exemplo, "saca de açúcar, tonel de carvão, baú de café, tora de madeira"; e outros made in Nordeste, diga-se de passagem. Com o foguete bem carregado de produtos genuínos, prontos para serem comercializados e utilizados durante a longa odisseia, Tonheta "puxa" a "lavanca", "pisa" no pedal e parte para o espaço com "força total", onde conhece lugares diferentes e inimagináveis, que não poderiam ser visitados de uma outra forma, que não fosse numa viagem lúdica dessa natureza, na forma de galope à beira-mar, ao som de um maracatu.

O Tonheta é um personagem de base popular, e muitas histórias e casos dele são recorrentes e fazem parte do imaginário coletivo, seja através do picaresco de histórias de Pedro Malazarte, de Cancão de Fogo, 
ou em histórias presentes no bumba-meuboi, ou através de histórias minhas que fui relembrando. [...] Ele é meu Macunaíma, sem dúvida. Idealizei uma pátria, uma genealogia para ele. Criei dois atores ambulantes que contam a história daquele personagem. Elaborei um ambiente cenográfico: esses atores ambulantes vão pelo meio do mundo com um circo mambembe - um pano de roda, que é o circo mais pobre que existe, sem cumeeira. São atores que não têm uma visão 'erudita' do teatro e se valem, pra contar essa história, apenas de seus recursos. No Segundas histórias, por exemplo, eu fazia uma paródia: Tonheta cantava homenageando a sua amada, e faz uma recriação de uma ária de Rossine; isto é, são coisas de mentalidade popular, escutar coisas assim e reelaborá-las. (NÓBREGA apud CADENGUE, 1999, p. 54-55).

Para Suassuna (apud CADENGUE, 1999, p. 53), Tonheta representa as referências vividas pelo público e, portanto, faz parte do imaginário coletivo. "Tonheta é o Brasil se revelando. [...] Tem um ditado que diz: triste é o filho que não vê o pai ir adiante. Eu digo de forma diferente: triste é o pai que não vê seu filho ir adiante. Só um ator de gênio é capaz de fazer um espetáculo e uma performance como Nóbrega em Figural".

Sendo o personagem Tonheta uma espécie de símbolo da reunião de aspectos distintos que se propagam na realidade brasileira, mais especificamente, na nordestina, com experiências vivenciadas ou referências presentes no imaginário coletivo, é notório o reconhecimento que existe por parte do público, seja ele mais erudito ou popular. É através desses sucessivos "curto-circuitos" protagonizados pelo personagem ou pela 
grande diversidade de elementos presentes no todo da sua obra, incluindo a música, o canto, a dança, a interpretação, a mímica, o instrumentista, o bonequeiro e malabarista dos espetáculos circenses, que Nóbrega possibilita essa realimentação de práticas que, apesar de não mais fazerem parte do cotidiano da maioria das pessoas, estão presentes, seja de forma mais latente, ou em grande parte das vezes, de forma mais superficial, quase que inconsciente.

Vejamos então os casos das excelências, representadas no trabalho do artista na música Excelência, presente no disco Lunário Perpétuo. A obra é uma recriação literária de Ariano Suassuna, com as toadas populares, que foi musicada por Nóbrega, a partir de uma primeira versão do Quinteto Armorial. Na versão de Nóbrega, o louvor à Virgem Maria é dividido em duas partes, sendo a primeira em forma de lamento e a segunda em forma de $A B C$, como podemos verificar no trecho a seguir:

Uma excelência da Virgem,

Oh, mãe de Deus, rogai por ele, Mãe de Deus.

Mãe de Deus, Mãe de Deus.

Oh, Mãe de Deus, rogai por ele, Mãe de Deus.

Mãe de Deus, Mãe de Deus.

Oh, Mãe de Deus, rogai a Deus por ele.

Diz o A ... Ave Maria

Diz o B ... Brandosa e Bela

Diz o C ... Cofrim da Graça

Diz o D ... Divina Estrela

Diz o E ... Esperança Nossa

Diz o F ... Fonte de Amor

Diz o G ... Guia do Povo

Diz o H ... Honesta Flor 

Diz o I ... Incenso d'Alma
Diz o J ... Jóia Mimosa
Diz o K ... Coro dos Anjos
Diz o L ... Luz Formosa

A excelência é um canto de recomendação das almas, uma espécie de ritual fúnebre, com benditos e frases apenas rimadas, ainda muito cantado no meio rural nordestino, principalmente em Pernambuco, Paraíba e no Rio Grande do Norte, sendo uma prática ainda existente e presente na vida dos sertenejos dessas localidades, que celebram sua revificação. Também chamadas de incelências ou incelenças, trata-se de uma prática do catolicismo popular, igualmente cantadas em Portugal, nas regiões de Douro e Minho, das mais antigas regiões do país, com uma cultura rica no folclore minhoto ${ }^{7}$ que se realça nas festas e romarias. Sem deixar de mencionar a existência de certos romances de origem bíblica, cantados no Marrocos, que assim como as excelências, não podem ser interrompidos e apresentam algumas características semelhantes.

Chamamos atenção para um outro aspecto bem presente na discografia de Antonio Carlos Nóbrega, que diz respeito à recorrência de algumas temáticas, como, por exemplo, aspectos relativos a história. Na verdade, temas que descrevem aspectos que dizem respeito à formação do povo brasileiro, sem deixar de mencionar figuras presentes na história do descobrimento, como os colonizadores e colonizados, além de outros episódios da história do Brasil, como o arraial de Canudos e o líder Antônio Conselheiro; e os quilombos, com a presença de Zumbi, como podemos ver a seguir:

7 O folclore minhoto é bem conhecido em Portugal pelas suas danças tradicionais, como, por exemplo, os viras, cana verdes e chulas. 
Zumbi, um negro, respirando rebeldia, foge pra mata um dia à procura do Lugar. Era um Quilombo, a terra dos ex-escravos, todos livres, sem os travos, sem ter dono pra ferrar.

Vinham mestiços, índios chegavam do eito, todos lá tinham direito, preto, branco, sarará. Uma nação de iguais sem oprimidos, de homens livres e nascidos, crescidos sem apanhar.

O sol, o sol lá vem.

Eu namoro uma morena, que sou moreno também.

[...]

Uma cruzada

contra os povos livres, bravos, para mantê-los escravos, correram então a formar. E a batalha derradeira aconteceu, jamais dela se esqueceu quem nasceu nesse lugar. 

$[\ldots]$
Primeiro sonho
brasileiro, de igualdade,
fraterno, de liberdade,
ali veio se acabar.
Mas foi semente
e deixou ensinamento
que ainda está em tempo
de viver pra se sonhar.

Ao som de um maracatu, Nóbrega e Wilson Freire descrevem um fato histórico relativo ao Quilombo dos Palmares e a morte do seu líder, Zumbi, com os personagens reais dessa história, a exemplo do bandeirante Domingos Jorge Velho, líder do grupo que destruiu o Quilombo; e o próprio acontecimento histórico em si, descrito na música como o "primeiro sonho brasileiro de igualdade, fraterno, de liberdade".

Além da música Zumbi, identificamos como temáticas históricas as seguintes músicas: Truléu da Marieta, Truléu, léu, léu, léu, léu; Canudos, Chegança, Quinto Império, Olodumaré, Nau, Romance do Aleijadinho, Galope Beira-Mar para o Bispo do Rosário, Romance da Filha do Imperador do Brasil e, finalmente, Romance de Riobaldo e Diadorim. As músicas Chegança e Olodumaré estão presentes em dois trabalhos recitais do artista, o disco Madeira que cupim não rói e Pernambuco Falando para o Mundo. A música Nau, composta por Antonio José Madureira no ano de 1989, presente no disco o Marco do Meio-Dia, mesmo sendo instrumental, foi incluída nesse núcleo temático por ser dedicada à figura do português colonizador. Dentro desse núcleo temático, pode ser observado um número maior relativo aos temas que tratam diretamente do descobrimento do Brasil, como acontece nas músicas Quinto 
Império, Olodumaré, Nau e Chegança; essa última apresentada no exemplo abaixo:

\author{
Sou Pataxó, \\ sou Xavante e Cariri, \\ Ianomami, sou Tupi \\ Guarani, sou Carajá. \\ Sou Pancaruru, \\ Carijó, Tupinajé, \\ Potiguar, sou Caeté, \\ Ful-ni-ô, Tupinambá. \\ Depois que os mares \\ dividiram os continentes, \\ quis ver terras diferentes. \\ Eu pensei: 'vou procurar \\ um mundo novo, \\ lá depois do horizonte, \\ levo a rede balançante \\ pra no sol me espreguiçar'. \\ Eu atraquei \\ num porto muito seguro, \\ céu azul, paz e ar puro... \\ botei as pernas pro ar. \\ Logo sonhei \\ que estava no paraíso, \\ onde nem era preciso \\ dormir para se sonhar.
}




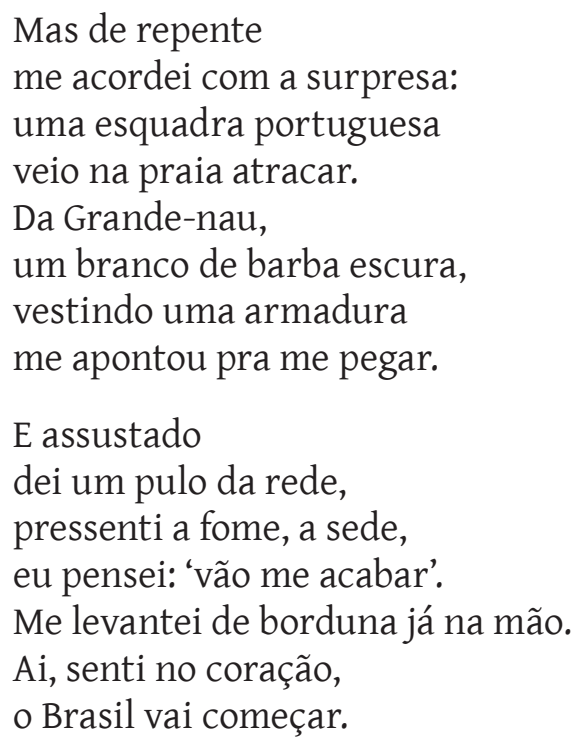

Mais uma parceria entre Antonio Carlos Nóbrega e Wilson Freire, Chegança fala da chegada dos portugueses e do começo da colonização. Logo no início, surgem algumas das tribos indígenas que habitaram o Brasil antes da chegada dos portugueses. Esse mesmo trecho acompanha toda a execução da música num refrão que se repete ao final de cada uma das estrofes. Ao som de um caboclinho, o personagem indígena narrador fala da vida tranquila e descreve a chegada da esquadra portuguesa. E com sua chegada, ele pressente e anuncia: "O Brasil vai começar".

Um outro núcleo narrativo significativo presente na discografia de Nóbrega diz respeito ao Nordeste. São músicas que falam, de alguma forma, da saga do homem nordestino, da situação do sertanejo na busca de uma situação de vida melhor fora do seu local de origem. É o caso da música Andarilho, de autoria de Dalton Vogeler e Orlando Silveira, gravada por Nóbrega no disco Madeira que cupim não rói: 
Caí do céu por descuido, se tenho pai, não sei não. Venho de longe, seu moço, lugar chamado sertão. Vivo sozinho no mundo, zombei da sede, zombei.

Cortei com a minha peixeira todo o mal que encontrei.

Fui caminhando, enfrentando as terras que o sol secou, até chegar à cidade dos homens que Deus olhou. Que o santo padre perdoe a triste comparação: melhor viver no cangaço que na tal civilização.

Brinquei com o mal, brinquei, sorri quando matei. Eu vim pra ser melhor, cheguei aqui, chorei.

A música, executada por Nóbrega no ritmo do baião, fala da saída de um retirante, o "Andarilho", que ao chegar à cidade "dos homens que Deus olhou" se depara com uma realidade ainda mais dura, a da civilização e dos seus excluídos. A letra parece ainda uma confissão do "Andarilho" ao "Santo Padre" da sua peregrinação, com sua história de vida, seus anseios quanto ao novo e a decepção ao chegar, retratada no refrão da música: "Brinquei com o mal, brinquei, sorri quando matei. Eu vim pra ser melhor, cheguei aqui, chorei". 
Além da música Andarilho, fazem parte dessa temática as seguintes músicas: 0 Vaqueiro e o Pescador, Rasga Nordeste e Pau-dearara. Um percentual de 5,13\% que, somado aos 17,94\% relativos aos temas históricos, apontam para um total de $23,07 \%$ na discografia do artista. Um número considerável dentro da produção de Antonio Carlos Nóbrega que não deixa de remeter a duas outras propostas do Armorial: a primeira, relativa à identificação dos temas históricos no seu trabalho, diz respeito à formação do povo brasileiro a partir do branco, negro e índio. Novamente, o Armorial se faz aí presente. A identidade nacional, compreendida por Suassuna, também se baseava na mistura dessas três raças, sendo a influência ibérica, expressão de peso para a definição nacional. A outra proposta, já evidenciada no primeiro capítulo do presente estudo, refere-se à identificação do núcleo temático Nordeste na produção do artista. Essa temática está bem presente na elaboração dos trabalhos dos armorialistas, que apontam a região nordestina como detentora de características singulares, portadora da expressão mais autêntica da cultura brasileira.

\section{As imagens como palavras: um outro texto}

O princípio de aproximar palavras e imagens está no cerne do fazer artístico do Movimento Armorial. Foi através do trabalho de ilustração d'A Pedra do Reino que Ariano Suassuna deu continuidade a sua produção em torno das artes plásticas. Essa e outras experiências anteriores em desenho, pintura e tapeçaria serviriam, mais adiante, para a produção dos álbuns de iluminogravuras, quando ele aprofundou ainda mais a integração entre texto e ilustração, representando cada álbum um livro de poemas.

O sonho de unir o texto literário e a imagem num só emblema, para que a Literatura, a Tapeçaria, a Gravura, a Cerâmica e a Escultura falem, todas, através de imagens 
concretas, firmes e brilhantes, verdadeiras insígnias das coisas. Insígnias de qualquer maneira desenhadas, gravadaseiluminadas - sobre surpefícies de pedra, de barro-queimado, de tecido, de couro, de áspero papel, ou, então, modeladas pela forma e pela imagem da palavra. (SUASSUNA apud NEWTON JÚNIOR, 1999, p. 123).

Em Antonio Carlos Nóbrega, as imagens também vão cumprir uma função determinante em relação às propostas preconizadas pelo Movimento Armorial. A partir dessa perspectiva, abrimos aqui um espaço para proceder a uma leitura cursiva das associações de imagens e palavras que estão nas capas de discos do artista. Tais aspectos vêm presentes, inclusive, no cenário de suas apresentações e na sua caracterização em palco, juntamente com seus músicos, explorando esse universo com fortes representações pictóricas.

A capa do disco Na pancada do Ganzá apresenta o artista situado ao lado direito, portando uma rabeca, numa foto posada, ocupando todo esse lado da capa. Pode-se identificar, num segundo plano, uma espécie de paisagem rural noturna, com um possível candeeiro iluminando a frente de uma casa de taipa, dando um sentido bucólico ao ambiente. A predominância de tonalidades pastéis também acentua o caráter mais rural à imagem.

O título Na Pancada do Ganzá vem situado do lado esquerdo inferior da capa, justamente no ponto de dispersão do campo de visão, depois do olhar percorrer todos os elementos, no ponto de saída. A disposição dos elementos evidencia uma preocupação no equilíbrio da capa, com as chamadas zonas mortas devidamente ocupadas, já que o braço da rabeca se estende até a parte superior direita. O candeeiro também se localiza num ponto de equilíbrio, preenchendo um espaço vazio da capa. o título do 
disco vem todo numa tonalidade escura que se confunde com a cor da capa no seu segundo plano, propiciando um aspecto tosco ainda mais intenso.

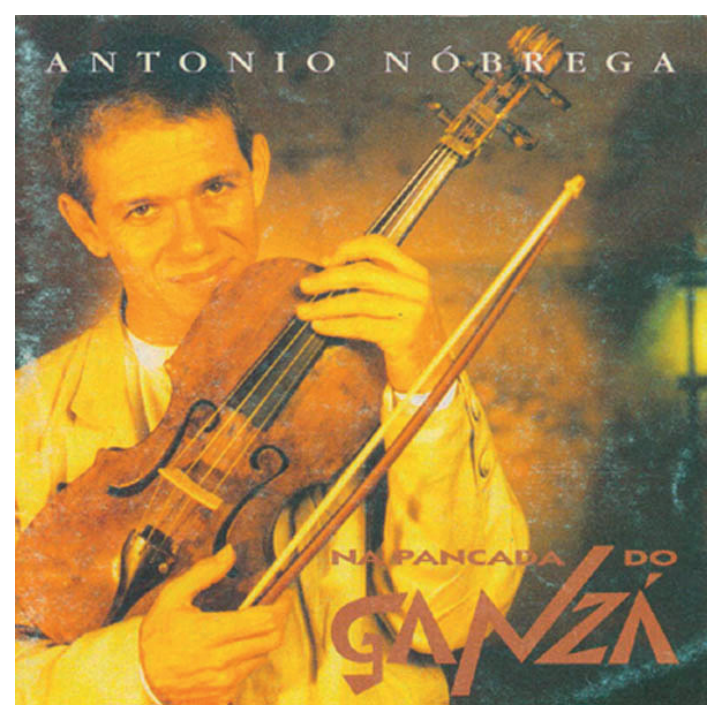

FIGURA 2 - Capa do disco Na Pancada do Ganzá

Nesse primeiro disco, Nóbrega trabalha a presença de elementos ligados ao popular. Além da presença de um instrumento de origem popular, a rabeca, a imagem remete ao meio rural, com a presença de um candeeiro e de uma casa de taipa, ligados diretamente aos aspectos do homem do Sertão, no seu espaço de vida natural, como ele é retratado. 0 próprio título do disco é também o título de uma música de autoria de Nóbrega, em parceria com Wilson Freire, e trata de elementos ligados à cultura popular. 
O disco Madeira que cupim não rói (Na Pancada do Ganzá II) tem sua ordem invertida, com o músico Antonio Carlos Nóbrega ocupando toda a extensão esquerda do disco, portando um urucungo ${ }^{8}$. Novamente numa foto posada, volta-se a ver a preocupação com as chamadas zonas mortas. Ao lado direito, o título do disco divide espaço com um pedestal, com destaque para a presença da rabeca.

Ao fundo, um cenário em tonalidade cinza faz florescer um sentimento de nostalgia, com a presença evidente do Carnaval, através da identificação de confetes caindo do alto. Um detalhe importante nessa capa é em relação à indumentária do músico, que remete a um período clássico, com um detalhe - o material dessas vestes seria feito de forma artesanal. Observa-se que existe uma preocupação em fundir elementos populares e eruditos também nesse trabalho. A rabeca não é colocada à toa na parte inferior direita da capa. Ela está ali, representando o elemento popular que divide espaço com outros aspectos, mais eruditos, como o próprio traje do artista.

8 O urucungo, como afirma o próprio Antônio Carlos Nóbrega, representa o "elo perdido" entre o berimbau e a rabeca, assim como a rabeca fica entre o violino moderno e o urucungo, observando-se assim uma perquirição etnomusicológica. 


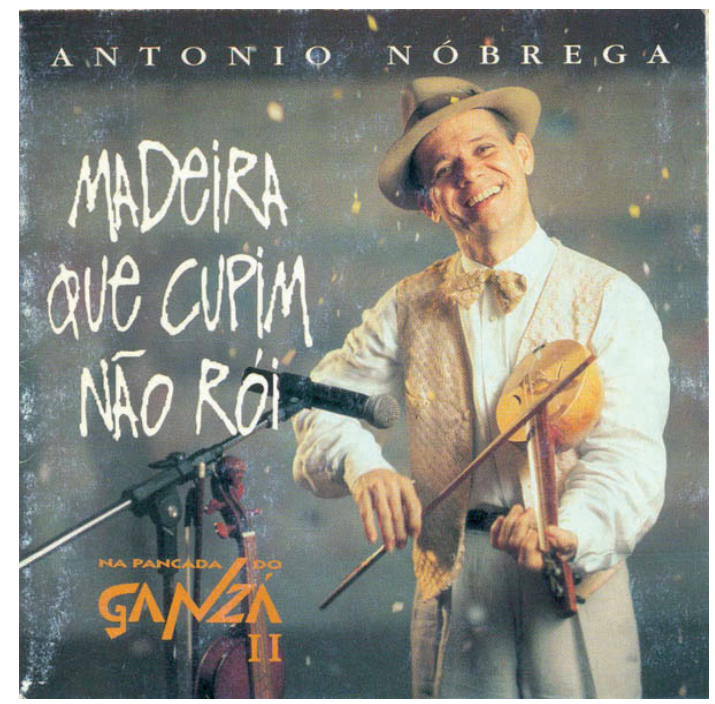

FIGURA 3 - Capa do disco Madeira que cupim não rói

Na capa, o título Madeira que cupim não rói, nome de uma consagrada marcha de bloco do Carnaval de Pernambuco, de autoria do músico Lourenço da Fonseca Barbosa, o Capiba, apresenta-se como riscos numa casca de árvore. Ou seja, a madeira foi riscada, mas o cupim não estragou a madeira. Na verdade, a letra da música trata da história de um dos blocos de carnaval mais tradicionais de Recife, que tem em sua temática a injustiça na avaliação de uma comissão julgadora. Mesmo injustiçado, o bloco não desiste e se apresenta como o verdadeiro campeão do Carnaval.

Pernambuco falando para o mundo, como podemos verificar, apresenta o artista numa foto tirada de um ângulo superior, com Nóbrega ocupando o lado esquerdo da capa, tendo em suas mãos mais uma vez a rabeca. o título do trabalho apresentase do lado direito, no intuito de proporcionar um equilíbrio da capa. 
Aspecto novo neste disco, em relação aos trabalhos anteriores, diz respeito à fotografia do artista, numa espécie de moldura, através de um desenho do artista plástico Dantas Suassuna. A foto apresenta também um exemplo de foto em perspectiva, com as pinturas dando uma impressão de movimento à foto.

Ao contrário dos outros dois trabalhos anteriores, quando Antonio Carlos Nóbrega se apresentava numa foto posada, neste trabalho, o artista aparece em movimento, portando a rabeca, como se estivesse executando um dos seus movimentos característicos. Seus trajes apresentam as mesmas pinturas e desenhos de Dantas Suassuna que, diga-se de passagem, é um dos representantes do Movimento Armorial na área das artes plásticas.

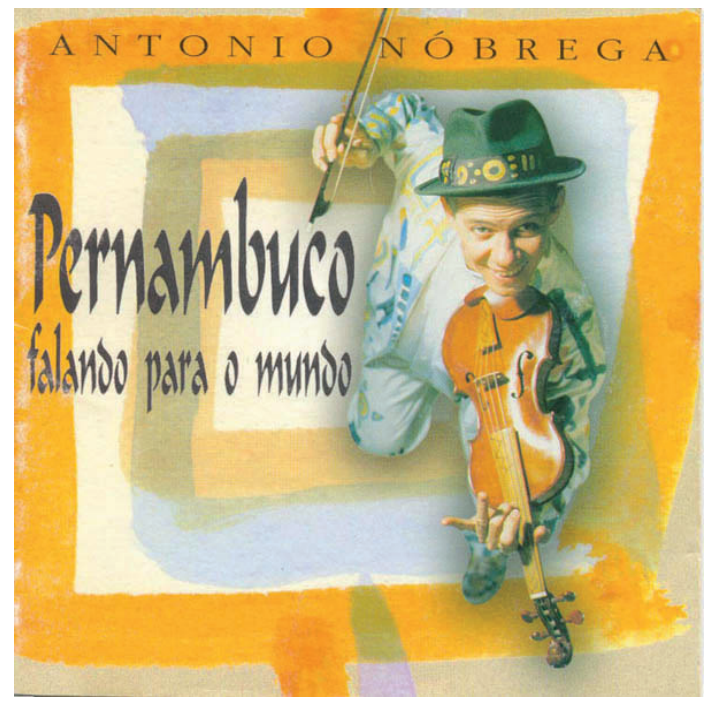

FIGURA 4 - Capa do disco Pernambuco falando para o mundo 
Trata-se de um disco que apresenta novamente o Carnaval, com marchas consagradas e outras músicas de Nóbrega, executadas ao ritmo pernambucano. As cores vivas utilizadas remetem a esse ambiente de festa que magnetiza o público, com destaque para a utilização do amarelo, eficaz no processo de comunicação e que proporciona, ainda, uma associação afetiva, correspondente à alegria e à energia.

Mais uma vez, são encontradas características que evidenciam elementos populares na obra de Nóbrega: a presença da rabeca, a sua indumentária, além do próprio título do trabalho e título de uma das músicas do disco, de autoria de Nóbrega e Wilson Freire, que diz respeito a elementos pertencentes ao imaginário coletivo nordestino.

Em O Marco do Meio Dia, Nóbrega aparece portando novamente a rabeca, numa foto durante apresentação em palco. Dessa vez, situado no centro da capa, os elementos que dão o equilíbrio necessário estão num segundo plano, com uma representação de Nóbrega à direita e a estrela d'Marco do Meio Dia, à esquerda.

Ao fundo, na parte inferior, o cenário lembra uma espécie de vila do Nordeste brasileiro, com casas semelhantes, umas com os muros encostados nas outras. $\mathrm{O}$ ambiente aponta para uma paisagem rural. As pinturas e desenhos presentes na indumentária e no cenário do espetáculo trazem, por sua vez, aspectos relacionados ao período medieval, na Península Ibérica, com a presença de "figuras monstruosas, bestas-feras, animais alados e todo um repertório de imagens fantásticas de inspiração árabe" (NEWTON JÚNIOR, 1999, p.124). 


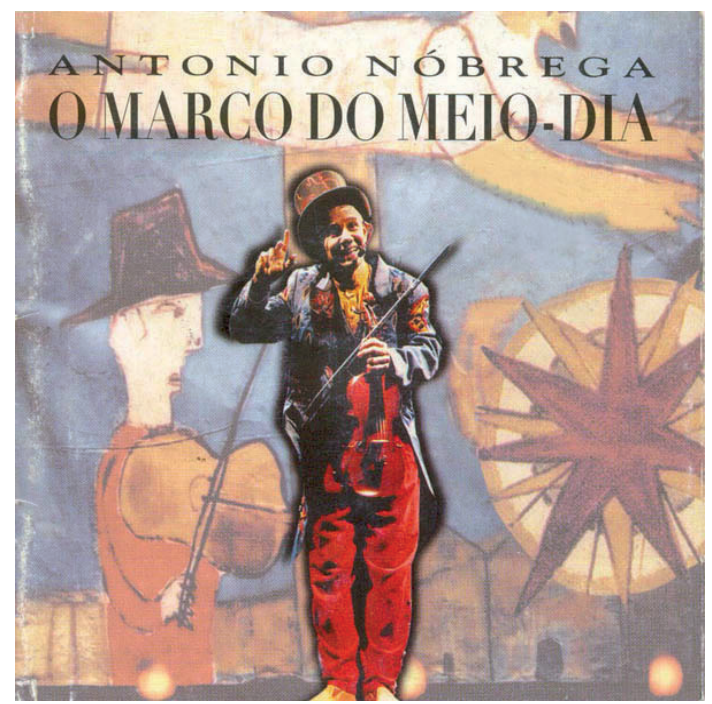

FIGURA 5 - Capa do disco O Marco do Meio Dia

Um aspecto que não vem evidente na capa, porém pode ser identificável no contexto do encarte como um todo, é a presença das iluminogravuras, que também faz parte dos trajes dos músicos e do próprio Nóbrega, que explora esses elementos, unindo-os uns aos outros e formando um todo no seu trabalho, que reflete a arte Armorial.

Já o disco Lunário Perpétuo apresenta-se com uma diversidade de elementos não comparada a nenhum dos trabalhos anteriores. A começar pelo aspecto envelhecido do material que compõe o encarte, numa alusão ao antigo livro que circulou, até meados do século XIX, no Nordeste brasileiro.

O Lunário Perpétuo era um dos livros mais lidos nos sertões do Nordeste, sendo uma das principais fontes de referência e conhecimento para as pessoas, além de bastante explorado, também, por poetas populares. Ele trazia um pouco de tudo, 
de astrologia, horóscopo, receitas médicas e mitologia, até conhecimentos agrícolas e conselhos de veterinária. Um livro, portanto, que tratava diretamente de temas ligados às necessidades das camadas mais populares. Sendo assim, a proposta de capa, necessariamente, teria que estar ligada a essa natureza e daí o aspecto envelhecido, já que se trata de um livro de circulação no século passado, desgastado pelo tempo.

Uma moldura incorpora todos os elementos da capa do disco, o que torna a leitura do objeto mais direcionada e constante, sem a dispersão do olhar, tendo em vista que o observador fixa e prende mais seu olhar em decorrência da moldura. Pode ser verificada uma preocupação com a disposição dos elementos, de forma que todos os espaços encontram-se devidamente preenchidos, sem que, no entanto, exista uma poluição visual, apesar da grande quantidade de textos contidos na capa.

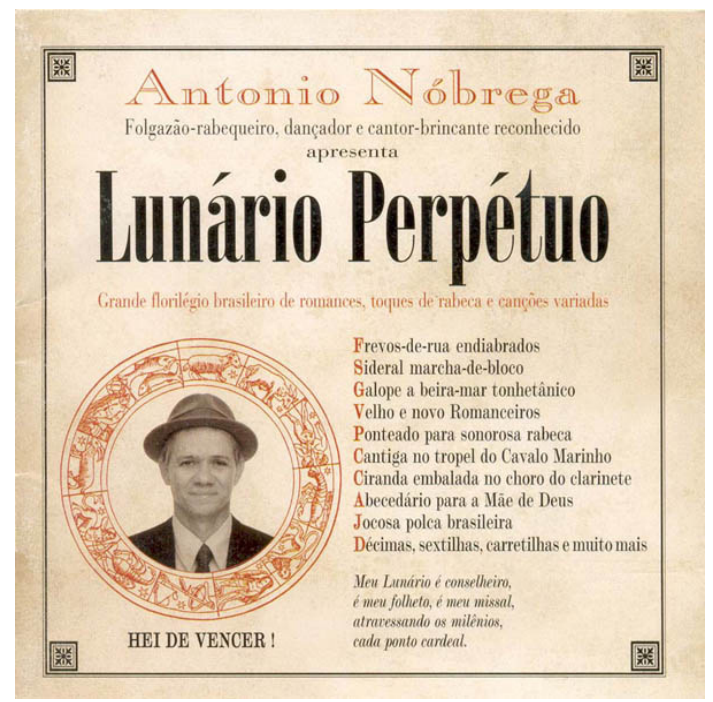

FIGURA 6 - Capa do disco Lunário Perpétuo 
Nesse trabalho, Nóbrega encontra-se localizado na parte inferior do lado direito, numa foto em preto e branco, de busto, que mais se parece com as fotos tiradas nas antigas máquinas de "lambe-lambe". Ao seu redor, uma espécie de círculo com o horóscopo e a presença de todos os signos. Esse elemento é apenas um em todo o encarte que contém uma ilustração do livro Lunário Perpétuo.

Ao lado esquerdo do disco, uma breve apresentação dos ritmos que fazem parte do conteúdo da obra, como os frevosde-rua, marchas-de-bloco, galopes à beira mar, loas, cirandas, polcas, entre outros. No ponto de saída do olhar, que se dá de cima para baixo, na diagonal, encontra-se a frase "Meu Lunário é conselheiro, é meu folheto, é meu missal, atravessando os milênios, cada ponto cardeal", que aponta para o livro como uma espécie de ponto de referência para os nordestinos.

Um aspecto chama atenção nessa obra em relação às anteriores. A ausência da rabeca com o músico. No entanto, ela aparece em dois momentos, não como representação simbólica, mas como palavra escrita. A primeira delas logo abaixo do nome do artista, num texto centralizado, que diz "Folgazãorabequeiro, dançador e cantor-brincante reconhecido". O outro momento em que a rabeca se faz presente é abaixo do título do disco, quando se verifica a frase "Grande florilégio brasileiro de romances, toques de rabeca e canções variadas".

As cores que compõem a capa do disco também foram pensadas no protótipo original, ou seja, no antigo livro. Além do preto e branco, com um fundo num certo tom pastel, que dá o envelhecimento característico da obra, a presença do vermelho dá um toque especial e de destaque para determinados aspectos do disco. A cor vermelha atua tanto no sentido de destacar pontos da obra, como também no que se refere propriamente à programação visual, associando-se à energia, esplendor, 
intensidade e glória. Não por acaso, abaixo do retrato três por quatro do artista, destaca-se a frase "Hei de vencer!".

Mais uma vez, o armorial apresenta-se de forma clara. Desde o trabalho de resgate e recriação de uma obra como o Lunário Perpétuo, pertencente às tradições e crenças do homem nordestino, o disco como um todo remete à obra original. 0 elemento erudito vem presente na breve apresentação da obra constante da capa, remetendo aos romances de origem ibérica. Os traços populares, por sua vez, estão em cada ponto do disco, inclusive no próprio sentido das frases de efeito utilizadas. Lunário Perpétuo corresponde, também, a uma música que integra o trabalho.

Composta por Nóbrega, Wilson Freire e Braulio Tavares, a sua letra fala da representatividade e utilidade do livro para os nordestinos.

\author{
Meu lunário tem antigas \\ alquimias de almanaque. \\ Já enfrentou intempéries, \\ roubos, incêndios e saques: \\ dos homens, das traças, das garras das eras. \\ Carrega segredos, decifra quimeras, \\ venceu todos os ataques. \\ $[\ldots]$ \\ O meu Lunário Perpétuo \\ é meu livro precioso, \\ minha Cartilha primeira, \\ minha Bíblia de Trancoso. \\ João Grilo, Chicó, Malazartes, Mateus, \\ os órfãos da terra, os filhos de Deus, \\ heróis do Maravilhoso.
}




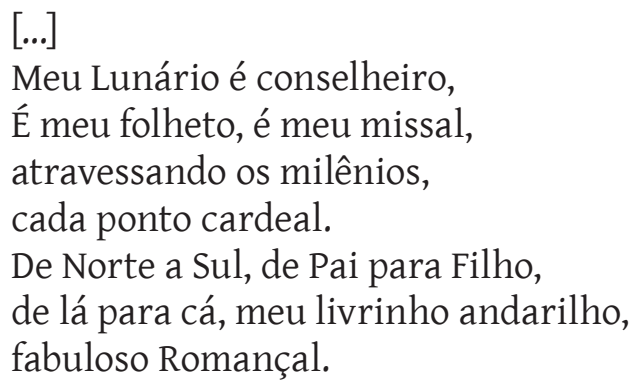

Outro ponto que merece destaque na análise refere-se a um elemento presente no Lunário Perpétuo, identificado como o trabalho do músico que carrega em si o maior número de características e possibilidades a serem verificadas dentro do Armorial. Esse elemento diz respeito à frase "Hei de Vencer!". Verifica-se aí uma preocupação dentro do Armorial que diz respeito à abordagem dos temas relativos à busca de uma melhor condição de vida para o povo, sem perder de vista a valorização, o resgate e a preservação de valores culturais próprios ao país.

Ao trazer os diversos elementos presentes no disco Lunário Perpétuo, Nóbrega mais uma vez trabalha com a perspectiva Armorial de recriação das artes, presente sob os diversos aspectos. Desde a caracterização da capa do disco, com os vários elementos presentes no que se refere às temáticas extraídas diretamente do livro Lunário Perpétuo, até os temas das músicas do trabalho.

Os discos Na Pancada do Ganzá, Madeira que cupim não rói, Pernambuco falando para o mundo, O Marco do Meio-Dia e Lunário Perpétuo apresentam aspectos vários que caracterizam o Movimento Armorial. Tais aspectos poderiam ser reconhecidos no resgate de elementos pertencentes às tradições e crenças do homem nordestino. Isso sem perder de vista os aspectos 
eruditos, seja na presença de instrumentos de origem ibérica, como é o caso do urucungo, presente na capa do disco Madeira que cupim não rói; seja, ainda, nas indumentárias do artista, como acontece n'O Marco do Meio-Dia, com a presença das iluminogravuras, criadas por Ariano Suassuna, que como foi visto, em momento anterior, tem origem na iluminura medieval.

No que se refere aos elementos que caracterizam o popular nas capas dos discos de Nóbrega, esses vêm representados de forma ainda mais acentuada. Um aspecto importante que ganha destaque nesse contexto é a presença constante da rabeca em todos os trabalhos do artista. Nos cinco discos, o instrumento aparece sempre presente, seja por inteiro, como nos discos $\mathrm{Na}$ Pancada do Ganzá, Pernambuco Falando para o Mundo e 0 Marco do Meio-Dia; seja em parte, como no Madeira que cupim não rói, quando a rabeca vem presa ao pedestal de um microfone; seja, finalmente, através da representação escrita, a palavra, como acontece no Lunário Perpétuo.

Seguindo as referências propostas pelo Movimento Armorial, Nóbrega mantém uma base de origem ibérica e da arte popular nordestina. O que se registra, enfim, é a presença constante e rica de elementos eruditos e populares nos discos de Antonio Carlos Nóbrega. Dessa forma, as capas da discografia do artista representam, também, um espaço que caracteriza a permanência da arte armorial no atual cenário cultural brasileiro e atuam ainda como elementos identificadores perante os diversos públicos, que se encontram e reencontram na diversidade de formatos que expressam o fazer artístico do Armorial sob diversos prismas. 
Considerações finais 



\section{Reconhecendo-se no Armorial}

Ao longo de suas fases, o Movimento Armorial conseguiu desempenhar algo único e original na cultura brasileira: a reunião de vários artistas com um mesmo propósito. Nas suas diferentes gerações, pintores, poetas e gravadores, músicos e escritores, ceramistas, bailarinos e homens de teatro apresentavam suas propostas ligadas aos postulados centrais do Movimento criado por Ariano Suassuna.

O processo de resistência do Movimento continua não somente através desses trabalhos e artistas, mas também através das críticas que continuam a existir, sejam contra o Movimento e seu mentor intelectual ou, ainda, contra os seus representantes na atualidade que de uma forma ou de outra continuam a levar adiante o projeto maior de Ariano Suassuna.

Uma dessas críticas, que diz respeito ao fazer artístico Armorial, enquanto uma atividade destinada a intelectuais, a uma elite, motivou e serviu de base para a elaboração do presente estudo. Não nos detivemos, no entanto, especificamente nessa discussão no que se refere ao Movimento, mas a um dos seus principais representantes na atualidade: o músico Antonio Carlos Nóbrega. Dessa forma, partimos da perspectiva de que o artista, em seus espetáculos, consegue acabar com a distinção de público, de forma que, tanto o público mais erudito, quanto o mais popular, se reconhecem no Armorial. 
Como foi visto, ao longo do trabalho, alguns elementos presentes na obra do artista ampliam e intensificam essa abordagem proposta pelo Armorial. É o caso da reunião dos diversos elementos relativos à cultura popular, como o uso das formas poéticas do romanceiro popular nordestino, como o repente, o martelo agalopado, o galope à beira-mar, o martelo gabinete ou as décimas de sete sílabas, para citar apenas alguns dos estilos mais usuais; e a recriação de núcleos temáticos elaborados, a partir desse mesmo universo, como observamos o caso do poema A Morte do Touro Mão de Pau, de autoria do poeta Fabião das Queimadas, recriado por Ariano Suassuna e, posteriormente, retrabalhado musicalmente por Antonio Carlos Nóbrega.

Um outro elemento de forte ligação entre sua obra e a arte popular é o aspecto emblemático, presente de forma decisiva na valorização e elaboração imagética em torno do seu trabalho poético, ressaltado ainda mais na sua caracterização em palco. Esse aspecto é ainda mais valorizado, a partir de sua atuação, com interpretação dos vários personagens, trazendo a técnica de séculos atrás dos artistas populares em representar diversos papéis em um mesmo espetáculo, como é o caso dos bonecos de mamulengo e do cavalo-marinho.

Papéis esses que são formados a partir da construção de outros vários personagens da vida real, presentes no "aqui" e "ali" da "Ilha Brasil". Na verdade, máscaras elaboradas a partir de um mundo e de uma realidade próximos, possibilitando o reconhecimento através de um elemento presente de forma significativa no fazer artístico popular, que diz respeito à memória, como foi mostrado ao longo da pesquisa. Constitui-se, a partir daí, a formação de uma identidade social que atua, de forma precisa, na representação e apropriação por parte dos indivíduos pertencentes a um determinado grupo. 
É o que pode ser visto no trabalho de Nóbrega no que se refere ao uso de alguns romances e loas, não apenas quanto a sua capacidade de interpretação de vários personagens que fazem parte de uma mesma história, mas também, quanto ao seu cantar. Em relação a isso, faz-se importante destacar um estudo realizado pelo músico Jarbas Maciel, ainda nas pesquisas das raízes populares desenvolvidas no DEC. Na oportunidade, o músico afirmava ter descoberto uma técnica que não iria passar despercebida aos olhos de pesquisadores e músicos sérios, como Guerra Peixe, Capiba, Clóvis Pereira e Cussy de Almeida.

A descoberta é a seguinte: o elemento primordial em composição armorial será, sempre, o contraponto modal, a harmonia modal nordestina resultando sempre no entrelaçamento das vozes. O problema técnico é difícil, porque - a exceção de Schillinger - não parece existir um sistema modal de escrituração contrapontística suficientemente geral para a criação de um 'novo estilo' como o armorial nordestino preconizado por Suassuna. Mas tem uma solução: basta aprendermos a cantar com os nossos cantores e rabequistas. (JARBAS MACIEL apud DIDIER, 2000, p. 111).

A afirmação reverbera em traços que podem ser associados a Antonio Carlos Nóbrega, que apresenta um cantar próprio dos cantadores. Para uma melhor compreensão desse aspecto, podemos observar uma afirmação do músico Antônio Madureira (MADUREIRA, 2002, p. 21), que, ao avaliar a maneira própria do cantar de Nóbrega, considera que ele desenvolveu um timbre de empostação vocal baseado em cantadores e aboiadores, ou seja, o timbre e a dicção são desenvolvidos na tradição nordestina. É 
o que pode ser verificado, de forma mais evidente, em algumas das gravações feitas por Nóbrega, como no caso específico da Excelência, presente no disco Lunário Perpétuo.

Reconhecendo-se no trabalho de Antonio Carlos Nóbrega, os diversos públicos se aproximam da proposta de criação Armorial. Esse estreitamento entre os elementos da Arte Armorial e público não é verificado apenas no seu trabalho poético. A instrumentação também aponta para uma perspectiva de reconhecimento semelhante, com a utilização de instrumentos que se enquadram naquilo que Suassuna apontava para a música Armorial.

Se na proposta do Quinteto Armorial, Suassuna apontava para a necessidade de utilização de instrumentos mais próximos do popular como forma de "reeducar" os músicos, como uma espécie de prática didática inicial, Nóbrega já não tem essa necessidade, com sua atividade musical voltada para elementos próprios da cultura popular, o que foi conseguido ao longo de sua trajetória de artista e do conhecimento estabelecido com a diversidade de elementos da cultura popular.

Apontamos, ainda, para as capas dos discos de Antonio Carlos Nóbrega como elementos que caracterizam, também, a permanência da Arte Armorial no atual cenário cultural brasileiro, atuando como elementos identificadores perante os diversos públicos, que se reconhecem na diversidade expressada pelo fazer artístico dos armorialistas.

A partir desses elementos, elucidamos dois outros aspectos de elaboração dos trabalhos armoriais presentes de forma bastante significativa na obra de Antonio Carlos Nóbrega. 0 primeiro deles é o princípio Armorial de criação, a partir de obras anteriores, possibilitando assim um aprofundamento da obra, sem esgotá-la e ampliando, inclusive, suas perspectivas de criação. Através desse, temos um outro aspecto também 
bastante evidenciado ao longo do estudo que se refere ao conceito de integração das artes, com as diferentes abordagens, originadas a partir de uma mesma obra. Abordagens essas em plena harmonia, complementando-se mutuamente e, assim, ampliando e enriquecendo, num movimento constante de circularidade.

Apesar do tempo de vigência maior do Armorial ter passado, o Movimento continua seu processo de resistência e amplia sua atuação através da influência, seja junto ao trabalho de grupos e artistas, como é o caso de Antonio Carlos Nóbrega, ou, ainda, apontando tendências na direção de outros movimentos que se espelham naquilo que o Movimento fez crescer ao longo dos seus mais de 40 anos de representatividade. É o caso do Movimento Manguebeat, surgido na década de 90, quando, mesmo não seguindo os ideais do Movimento Armorial, teve nele um impulso para a estruturação do seu projeto de criação e fundamentação, a partir de elementos da cultura popular. O próprio Chico Science, principal figura na formação da chamada Geração Mangue, mesmo não se enquadrando naquilo que Suassuna preconizava, dizia-se um Armorial.

Na sua atual fase, o Movimento Armorial pode ser visto através da influência que repercute em atividades diversas, que vão desde o teatro, através do Grupo Gesta; da dança, através do Balé Popular do Recife e do trabalho da bailarina Maria Paula Costa Rego, que fundou, em 1997, o Grupo Grial; das artes plásticas, com Gilvan Samico, Dantas Suassuna e Romero de Andrade Lima; da poesia e pintura, representadas por Virgílio Maia e sua esposa, a pintora Socorro Torquato; da literatura, por Carlos Newton Júnior e pelo próprio Ariano Suassuna; e até mesmo das experiências no design. Nesta área, no entanto, é preciso perceber que os designers são artistas que estão sujeitos às necessidades do mercado e desejo dos clientes, fazendo com que a influência do Movimento Armorial só apareça de forma isolada, como é o 
caso dos trabalhos de Dinara Moura e Nalba Diniz. Na música, os trabalhos de grupos como o Trio Romançal, o Quinteto da Paraíba, a Camerata Armorial, o Quinteto Itacoatiara, Sagrama, Anima e do próprio Antonio Carlos Nóbrega são algumas das referências atuais do Movimento Armorial.

Os diversos elementos explorados no presente estudo apontam para novas perspectivas a serem abordadas acerca do Movimento Armorial e, principalmente, do músico Antonio Carlos Nóbrega. Trazemos para o conhecimento público e debate acadêmico mais um capítulo dessa história, enfocando, principalmente, a música Armorial, ainda em carência no âmbito acadêmico, a partir do trabalho do músico Antonio Carlos Nóbrega, personagem importante na história do Movimento e na sua continuidade. Na verdade, o assunto não se esgota. Ao contrário, ampliam-se as possibilidades de abordagens para com um capítulo importante da cultura brasileira, que ainda carrega marcas e reflete o Movimento criado por Ariano Suassuna.

\section{Referências}

ANJOS, Moacir dos. Local/global: arte em trânsito. Rio de Janeiro: Jorge Zahar, 2005.

ARANTES, Antonio Augusto. 0 que é cultura popular. 14 ed. São Paulo: Brasiliense, 1990.

AYALA, Marcos.; AYALA, Maria Ignez Novais. Cultura popular no Brasil. São Paulo: Editora Ática, 2003.

BENJAMIN, Roberto. Os romances da tradição ibérica na obra midiática de Antonio Carlos Nóbrega. Disponível em: <http:// reposcom.portcom.intercom.org.br>. Acesso em 17 set. 2007. 
BENJAMIN, Walter. Magia, técnica, arte e política.São Paulo: Editora Brasiliense S.A, 1985.

BENNETT, Roy. Uma breve história da música. Trad. Maria Teresa Resende Costa. ed. 3. Rio de Janeiro: Jorge Zahar, 1986. (Obras escolhidas; vol. 1)

BITTER, Daniel. Da polifonia poética - visual nas artes armoriais. Arte e Ensaios - Revista do Programa de Pós-Graduação em Artes Visuais EBA. Rio e Janeiro, v.7, n. 7. p. 20 - 27, 2000.

BIZZOCCHI, Aldo. O clássico e o moderno, o erudito e o popular na arte. Líbero. São Paulo, v.2, n.3/4, p.72-76, 1999.

BOSI, Alfredo. Dialética da colonização. 4. ed. São Paulo: Companhia das Letras, 2001.

CADENGUE, Antônio. Educação pela máscara: recortes de uma genealogia de Antônio Nóbrega. Folhetim Teatro do Pequeno Gesto, [São Paulo], n. 5. p. 44 - 59, set./out. - nov./dez. de 1999.

CADERNOS DE LITERATURA BRASILEIRA: IMS, São Paulo, n. 10, nov. 2000.

CANCLINI, Nestor Garcia. Culturas híbridas - Estratégias para entrar e sair da modernidade. São Paulo: Edusp, 1997. (1989)

CANDIDO, Antonio. 0 discurso e a cidade. São Paulo: Duas Cidades, 1993.

CAROS AMIGOS, São Paulo: Casa Amarela, v.7, n.75, jun. 2003.

. São Paulo: Casa Amarela, v.7, n.82, jan. 2004.

CASCUDO, Luís da Câmara. Vaqueiros e cantadores. Rio de Janeiro: Edições de Ouro, 1968. 
COLI, Jorge. O que é arte. 5. ed. São Paulo: Brasiliense, 1984.

CONTINENTE MULTICULTURAL, Recife: CEPE, v.2, n. 14, fev. 2002.

. Recife: CEPE, v.2, n. 20, ago. 2002.

CYPRIANO, Fábio. ‘Guaraná Power' é vetada na Bienal. Jornal da Paraíba, Paraíba, 6 outubro 2006. Caderno Vida/Geral, p. 4.

DIDIER, Maria Thereza. Emblemas da sagração armorial: Ariano Suassuna e o Movimento Armorial (1970 - 76). Recife: Editora Universitária da UFPE, 2000.

FUNARI, Pedro Paulo Abreu. Cultura popular na antigüidade clássica. São Paulo: Contexto, 1989.

GEERTZ, Clifford. Ideology as a Cultural System. [s.d.]. Disponível em: <http://xroads.virginia.edu/g/DRBR/geertz.html>. Acesso em: 27 set. 2001.

A interpretação das culturas. Rio de Janeiro: Zahar Editores, 1978.

GIDDENS, Anthony. As conseqüências da modernidade. Trad. Raul Fiker. São Paulo: UNESP, 1991.

HALL, Stuart. A identidade cultural na pós-modernidade. 10 ed. Trad. Tomaz Tadeu da Silva e Guacira Lopes Louro. Rio de Janeiro: DP\&A, 2005.

JANGADA Brasil. Disponível em: <http://www.jangadabrasil.com.br>. Acesso em: 26 mai. 2007.

JOACHIM, Sebastien. A importância das literaturas marginais.

Cadernos Populares, [Campina Grande], v. 2, n. 8. p. 2-10, dez. 1996.

KUPER, Adam. Cultura. Bauru: EDUSC, 2002. 
LEITE FILHO, Aleixo. Noções de folclore. Recife: [s. n.], 1994.

LETRAS de Novelas. Disponível em: <http://www.letrasdenovelas. com.br>. Acesso em: 27 maio 2007.

LINS, Juliana; VICTOR, Adriana. Ariano Suassuna: um perfil bibliográfico. Rio de Janeiro: Jorge Zahar, 2007.

MADUREIRA, Antônio. Um artista de palco. In: Continente Multicultural, Recife: CEPE, v.2, n. 14, fev. 2002, p. 21.

MARCHIORI, Marlene. Cultura e comunicação organizacional: um olhar estratégico sobre a organização. São Caetano: Difusão Editora, 2006.

MARTINS, Wilson. O romanceiro da pedra e do sonho. Cadernos de Literatura Brasileira, São Paulo, [IMS], n. 10, IMS, p. 111-128, Nov. 2000 .

MERCADOR, Tonico. Alto do reino encantado. Revista Palavra, Belo Horizonte: GAIA, v. 1, n. 10, p. 16, Jan. / Fev. 2000.

NEWTON JÚNIOR, Carlos. Movimento Armorial. Correio da Paraíba, Paraíba, 13 jul. 2007. Caderno Cultura, p. 6.

O pai, o exílio, e o reino: a poesia armorial de Ariano Suassuna. Recife: Editora Universitária da UFPE, 1999.

. A ilha Barataria e a ilha Brasil. Natal: Editora Universitária da UFRN, 1999.

. Os Quixotes do Brasil: O Real e o Sonho do Movimento Armorial. Recife, 1990. Ensaio (Pós-Graduação) - UFPE.

NÓBREGA. Antonio. Tonheta. [2004] Disponível em: <http://www. antonionobrega.com.br>. Acesso em: 27 jan. 2004. 
ORTIZ, Renato. Cultura brasileira e identidade nacional. São Paulo: Brasiliense, 1994.

1994.

A moderna tradição brasileira. 5 ed. São Paulo: Brasiliense, PESAVENTO, Sandra Jatahy. História e história cultural. Belo Horizonte: Autêntica, 2003.

ROUANET, Sergio Paulo. As razões do Iluminismo. São Paulo: Companhia das Letras, 1987.

SAID, Edward. Cultura e Imperialismo. São Paulo: Companhia das Letras, 1995.

SALGADO, Ronaldo. Entrevista com Ariano Suassuna. [2007] Disponível em: <http://www.blogueisso.com/2007/01/20/entrevistacom-ariano-suassuna/\#more-1297>. Acesso em: 9 set. 2007.

SANTOS, Idelette Muzart Fonseca dos. O decifrador de brasilidades. Cadernos de Literatura Brasileira, São Paulo, n. 10, IMS, p. 94-110, Nov. 2000.

SUASSUNA, Ariano. Romance d'A Pedra do Reino e o Príncipe do Sangue do Vai-e-Volta. 7. ed. Rio de Janeiro: José Olympio, 2005.

. Auto da Compadecida. 35 ed. Rio de Janeiro: Agir, 2005.

. O movimento foi uma bandeira. Continente Multicultural, Recife: CEPE, v.2, n. 14, p. 19-20, fev. 2002.

. Poemas. Seleção, organização e notas Carlos Newton

Júnior. Recife: Editora Universitária da UFPE, 1999.

. A onça castanha e a ilha Brasil: uma reflexão sobre a cultura brasileira. Recife, 1976. Tese (Docência Livre) - UFPE. 
O Movimento Armorial. Recife: UFPE, 1974.

TAVARES, Braulio. ABC de Ariano Suassuna. Rio de Janeiro: José Olympio, 2007.

Contando história em versos: Poesia e Romanceiro popular no Brasil. São Paulo: Ed. 34, 2005.

TELES, José. Do frevo ao manguebeat. São Paulo: Ed. 34, 2000.

TINHORÃO, José Ramos. Pequena história da música popular: da modinha ao tropicalismo. São Paulo: Art Editora, 1986.

VASSALO, Lígia. O grande teatro do mundo. Cadernos de Literatura Brasileira, [São Paulo], IMS, n. 10, p. 147-180, Nov. 2000.

WALTER, Roland. Literatura comparada: diversidade, diferenças e fronteiras de identidades culturais. Revista Brasileira de Literatura Comparada, São Paulo, n. 9, 2005.

. Literatura, teoria literária e as diferenças culturais.

Investigações, lingüística e teoria literária, Recife,v.10, p. 75-107, 1999.

XIDIEH, Oswaldo Elias. Cultura popular. In: et al. Feira Nacional da Cultura Popular. São Paulo: SESC, 1976. 

Apêndices 



\begin{tabular}{|c|c|c|c|c|c|c|c|c|c|c|c|c|c|c|c|c|}
\hline soxino & & & & & & $x$ & & $x$ & & & & & & & $x$ & $x \mid$ \\
\hline 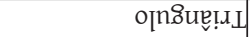 & & & & & $x$ & & & & & & & & & & & \\
\hline әиоquолI & & & & & & & $x$ & $x$ & & & $x$ & & $x$ & $x$ & & \\
\hline әтәdиолІ & & & & & & & & & & & $x$ & $x$ & $x$ & $x$ & & \\
\hline оитрлеqшод & & & & & & & & & & & & $x$ & & & & \\
\hline пұеэелеш әр лочше I & & & & & & & & & & & & & & $x$ & $x$ & \\
\hline equinqez & & $x$ & $x$ & & $x$ & & $x$ & $x$ & & $x$ & $x$ & $x$ & $x$ & & & \\
\hline Q.808 & & & & & & & & & & & $x$ & & & $x$ & & \\
\hline орәэиојо! $\Lambda$ & & & & & & & & & & & & & & & & $x$ \\
\hline oe $[0 ! \Lambda]$ & & & & $x$ & & $x$ & & & & & & & & & & $x \mid$ \\
\hline $\mathrm{xeS}$ & & & $x$ & $x$ & $x$ & & $x$ & $x$ & & $x$ & & $x$ & $x$ & & & \\
\hline ęzues & & & & & & & & & & & & & & $x$ & $x$ & \\
\hline ол!әрие $\mathrm{d}$ & & & $x$ & $x$ & $x$ & & $x$ & $x$ & & $x$ & & & $x$ & & $x$ & \\
\hline sepлог $\angle$ әр ое о & & & $x$ & $x$ & & & & & & $x$ & & & & & & \\
\hline ए๐o! $\Lambda$ & & & & & & & & & $x$ & & & & & & & \\
\hline очu!̣nbe^eว & & $x$ & $x$ & & $x$ & $x$ & $x$ & $x$ & & $x$ & $x$ & $x$ & $x$ & & & $x$ \\
\hline $\operatorname{sote}_{\mathrm{d}}$ & & $x$ & & & & & & & & & & & & & & $x \mid$ \\
\hline ex!̣eJ & & $x$ & & & $x$ & $x$ & & & & $x$ & & $x$ & $x$ & $x$ & & $x \mid$ \\
\hline шогрлоэн & & $x$ & $x$ & $x$ & $x$ & $x$ & $x$ & & & $x$ & $x$ & & & $x$ & & $x$ \\
\hline 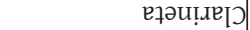 & & & $x$ & & & & $x$ & $x$ & & & & & & & & \\
\hline u!̣ne [a / eұne & & & & & & & $x$ & $x$ & & $x$ & $x$ & $x$ & $x$ & $x$ & & \\
\hline щ!̣ [ориеg] & & $x$ & & $x$ & & & & $x$ & & $x$ & & & & & & \\
\hline езәqеу & $x$ & & & & $x$ & $x$ & & $x$ & & $x$ & $x$ & $x$ & $x$ & & & $x$ \\
\hline 㺃 & శ్ర & $\begin{array}{l}\frac{\pi}{5} \\
\text { t. } \\
\sum\end{array}$ & $\frac{\pi}{\tilde{\varepsilon}}$ & $\frac{\pi}{\pi}$ & 总 & 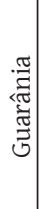 & 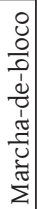 & 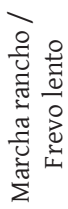 & $\begin{array}{l}\frac{\pi}{0} \\
0 \\
0 \\
0 \\
0 \\
. \frac{\pi}{0} \\
0 \\
0 \\
0 \\
0 \\
0\end{array}$ & 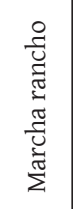 & $\begin{array}{l}0 \\
0 \\
x\end{array}$ & 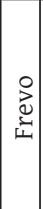 & 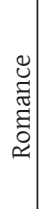 & 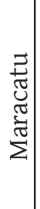 & 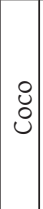 & 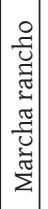 \\
\hline 莺 & 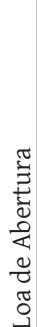 & 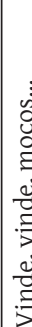 & 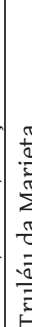 & 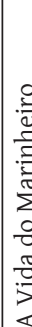 & 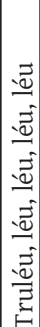 & 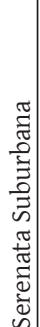 & 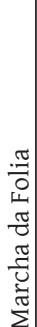 & 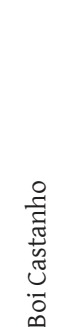 & 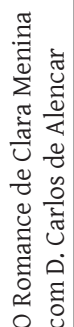 & 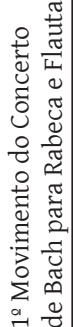 & 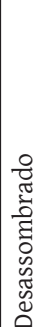 & 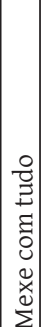 & 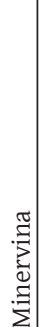 & 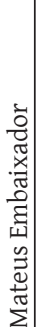 & 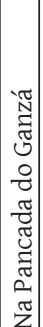 & 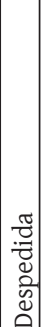 \\
\hline
\end{tabular}




\begin{tabular}{|c|c|c|c|c|c|c|c|c|c|c|c|c|c|c|c|c|c|c|}
\hline 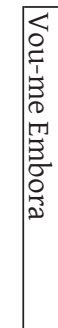 & \begin{tabular}{|l|}
$\infty$ \\
0 \\
3 \\
0 \\
0 \\
0 \\
0 \\
0 \\
0 \\
0 \\
0 \\
0 \\
3 \\
0 \\
0 \\
0 \\
0 \\
0 \\
0 \\
0
\end{tabular} & 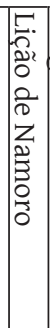 & 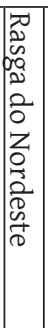 & 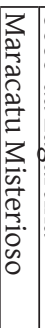 & 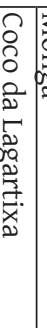 & & 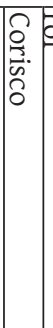 & 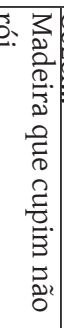 & 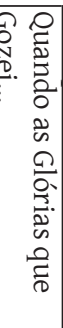 & 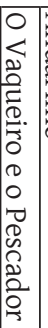 & & 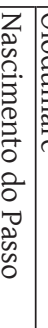 & 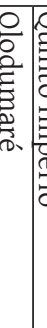 & & & & 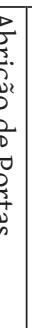 & 胥. \\
\hline 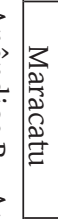 & 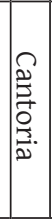 & 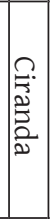 & 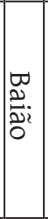 & 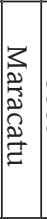 & ঠे & 永 & 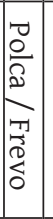 & 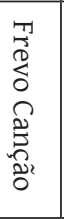 & 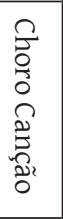 & $\begin{array}{l}\underset{D}{0} \\
\stackrel{0}{0}\end{array}$ & $\begin{array}{l}\mathscr{D} \\
\tilde{D} \\
\tilde{D}^{2}\end{array}$ & 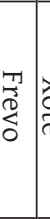 & & 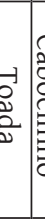 & 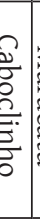 & $\begin{array}{l}\frac{3}{2} \\
\frac{2}{2} \\
\frac{2}{2} \\
\underline{2} \\
2\end{array}$ & $\begin{array}{l}2 \\
2 \\
2_{2} \\
b_{2}\end{array}$ & $\begin{array}{l}\text { T. } \\
\stackrel{2}{\Theta} \\
\stackrel{0}{0}\end{array}$ \\
\hline$x$ & & & $x$ & & $x$ & & & & $x$ & $x$ & $x$ & 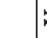 & $x$ & & $x$ & $x$ & $x$ & Rabeca \\
\hline & & $x$ & & & & & $x$ & $x$ & $x$ & & & $x$ & $x$ & & & & $x$ & Bandolim \\
\hline & & $x$ & $x$ & & & & $x$ & & & & & $x$ & & $x>$ & $x$ & $x$ & & Flauta / Flautim \\
\hline & & $x$ & & & & & & $x$ & $x$ & & & & & & & & & Clarineta \\
\hline & & $x$ & $x$ & & $x$ & $x$ & & $x$ & $x$ & $x$ & $x$ & $x$ & $x>$ & $x$ & & $x$ & & Acordeom \\
\hline & & $x$ & $x$ & $x$ & & $x$ & $x$ & $x$ & & & & $x$ & & 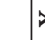 & $x$ & & & Caixa \\
\hline & & & & & & & & & & & & $x$ & & & & & & Pratos \\
\hline & & $x$ & $x$ & & & $x$ & $x$ & $x$ & $x$ & & $x$ & $x$ & $x ;$ & $x>$ & $x$ & & & Cavaquinho \\
\hline & $x$ & & $x$ & & & & & & & $x$ & $x$ & & & $x$ & & $x$ & & Viola \\
\hline & & & & & & & $x$ & & $x$ & $x$ & & & & & & & & Violão de 7 cordas \\
\hline$x$ & & & & & $x$ & $x$ & $x$ & $x$ & $x$ & & & $x$ & & $x$ & & & & Pandeiro \\
\hline$x$ & $x$ & $x$ & & $x$ & $x$ & & & & & & & & $x$ & & $x$ & $x$ & $x$ & Ganzá \\
\hline & $x$ & & & $x$ & & $x$ & $x$ & $x$ & & & & $x$ & & & & & & Sax \\
\hline & & & & & & & & & & & & & $x$ & & & & & Violão \\
\hline & & & $x$ & & & & & & & & & & & $x>$ & $x$ & $x$ & & Violoncelo \\
\hline & & & & $x$ & & & & & & $x$ & $x$ & & $x$ & & & & & Agogô \\
\hline & $x$ & & $x$ & & & $x$ & & $x$ & & & $x$ & & $x$ & & $x$ & & & Zabumba \\
\hline$x$ & & $x$ & & $x$ & $x$ & & & & & & & & & & & $x$ & & Tambor de Maracatu \\
\hline & & $x$ & & & & $x$ & $x$ & $x$ & & & & $x$ & & & & & & Bombardino \\
\hline & $x$ & $x$ & & & & $x$ & $x$ & $x$ & & & & $x$ & & & & & & Trompete \\
\hline & $x$ & $x$ & & $x$ & & $x$ & $x$ & $x$ & & & & $x$ & & & & & & Trombone \\
\hline & & & $x$ & & & $x$ & & & & & $x$ & & & & & & & Triângulo \\
\hline$x$ & $x$ & $x \mid$ & $x$ & $x$ & $x$ & & $x$ & & & $x$ & $x$ & & $x$ & $x=$ & $x$ & $\times$ & $x$ & Outros \\
\hline
\end{tabular}




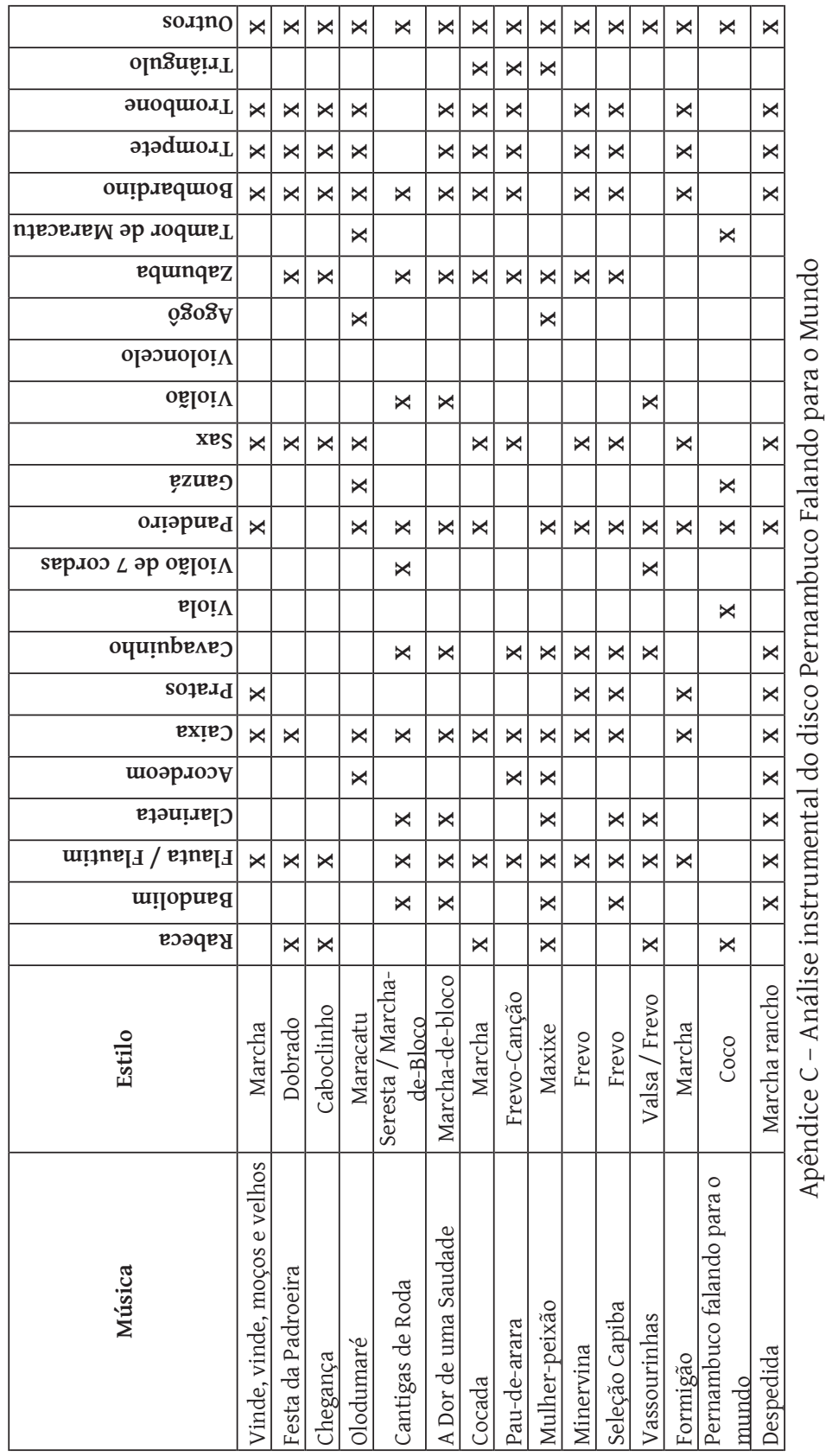




\begin{tabular}{|c|c|c|c|c|c|c|c|c|c|c|c|c|c|c|}
\hline 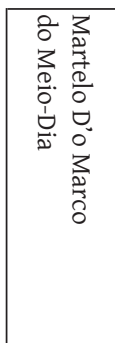 & 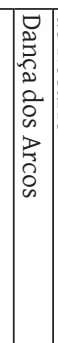 & 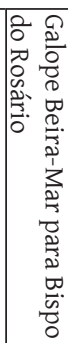 & 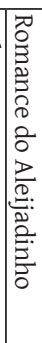 & 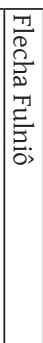 & 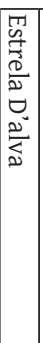 & & 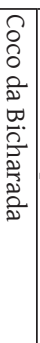 & 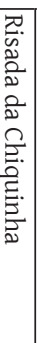 & 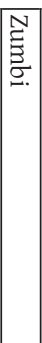 & 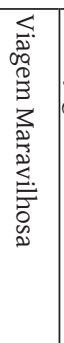 & 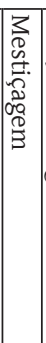 & 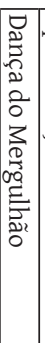 & 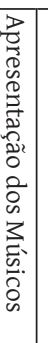 & 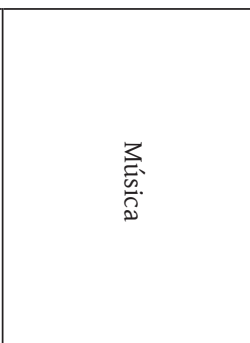 \\
\hline 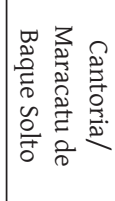 & 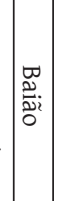 & $\begin{array}{l}3 \\
\stackrel{3}{n} \\
\overbrace{}^{2} \\
\stackrel{\Xi}{\Xi}\end{array}$ & 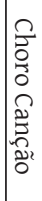 & 葍 & 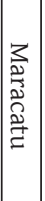 & $\frac{<}{2}$ & $\begin{array}{l}\delta \\
\delta\end{array}$ & $\frac{0}{\grave{D}}$ & 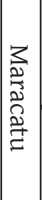 & 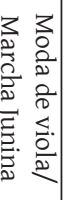 & $\delta$ & 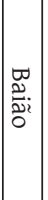 & 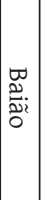 & $\begin{array}{l}\stackrel{1}{M} \\
\stackrel{\vec{E}}{\circ} \\
\end{array}$ \\
\hline$x$ & $x$ & & $x$ & & & & $x$ & $x$ & & & & $x$ & $x$ & Rabeca \\
\hline & & $x$ & & $x$ & $x$ & & & $x$ & & & & & & Bandolim \\
\hline$x$ & & $x$ & & $x$ & $x$ & $x$ & & & $x$ & $x$ & $x$ & $x$ & $x$ & Flauta / Flautim \\
\hline & & & & $x$ & $x$ & $x$ & & & $x$ & & $x$ & $x$ & & Clarineta \\
\hline & $x$ & $x$ & & & & $x$ & $x$ & $x$ & $x$ & $x$ & $x$ & & $x$ & Acordeom \\
\hline$x$ & & & & $x$ & $x$ & $x$ & & $x$ & $x$ & & & $x$ & & Caixa \\
\hline$x$ & & & & & & $x$ & & & & & & & & Pratos \\
\hline & & & & $x$ & & & & $x$ & & $x$ & $x$ & $x$ & & Cavaquinho \\
\hline$x$ & & $x$ & & & $x$ & & & & & $x$ & & & $x$ & Viola \\
\hline & & & $x$ & & & $x$ & & $x$ & & & & & & Violão de 7 cordas \\
\hline & $x$ & & & $x$ & & $x$ & $x$ & $x$ & & & $x$ & $x$ & & Pandeiro \\
\hline & $x$ & $x$ & & $x$ & $x$ & & $x$ & & & & & $x$ & $x$ & Ganzá \\
\hline$x$ & & & & $x$ & $x$ & & & $x$ & & & $x$ & & & Sax \\
\hline & & $x$ & $x$ & & & $x$ & & $x$ & $x$ & & & $x$ & $x$ & Violão \\
\hline & & & $x$ & $x$ & $x$ & $x$ & & $x$ & & $x$ & & & & Violoncelo \\
\hline & & & & & $x$ & & & & $x$ & & $x$ & & & Agogô \\
\hline$x$ & $x$ & & & $x$ & & & & & & $x$ & & $x$ & & Zabumba \\
\hline & & $x$ & & & $x$ & & $x$ & & $x$ & & $x$ & & & Tambor de Maracatu \\
\hline & & & & & & & & & & & & & & Bombardino \\
\hline$x$ & & & & & & & & & & & & & & Trompete \\
\hline$x$ & & & & $x$ & & & & & & & & & & Trombone \\
\hline & $x$ & & & & & & & & & $x$ & & & & Triângulo \\
\hline$x$ & $x$ & $x$ & $x$ & $x$ & $x$ & $x$ & $x$ & $x$ & $x$ & $x$ & $x$ & $x$ & & Outros \\
\hline
\end{tabular}




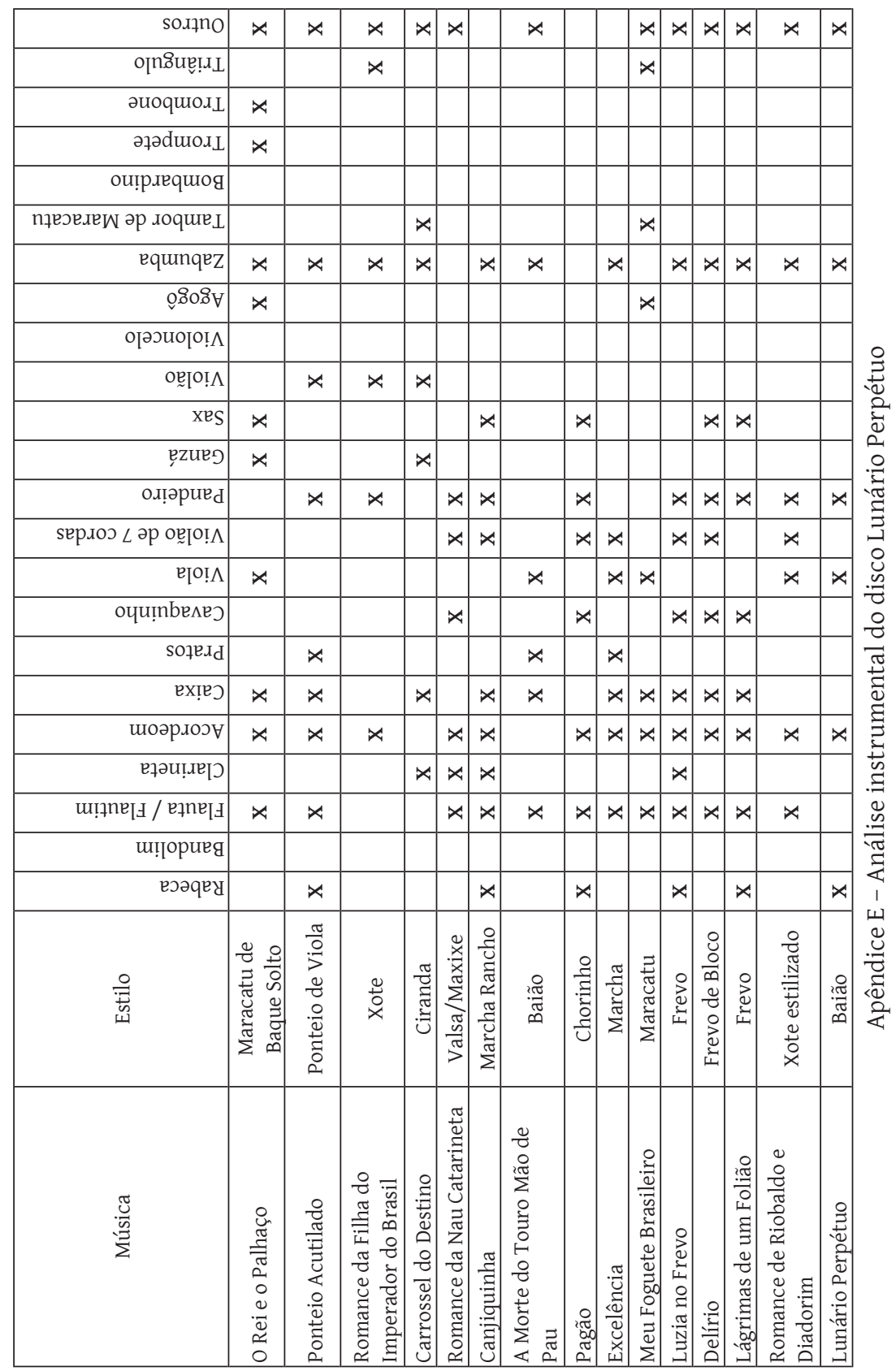




\begin{tabular}{|c|c|c|c|}
\hline \multirow{4}{*}{ METAIS (AEROFONES) } & Instrumentos & Quantidade & Percentual \\
\hline & Trombone & 26 & 33,3 \\
\hline & Trompete & 23 & 29,5 \\
\hline & Bombardino & 18 & 23,1 \\
\hline \multirow{8}{*}{$\begin{array}{c}\text { CORDAS } \\
\text { (CORDOFONES) }\end{array}$} & Instrumentos & Quantidade & Percentual \\
\hline & Cavaquinho & 40 & 51,3 \\
\hline & Rabeca & 38 & 48,7 \\
\hline & Bandolim & 20 & 25,6 \\
\hline & Viola & 19 & 24,3 \\
\hline & Violão de 7 cordas & 18 & 23,1 \\
\hline & Violão & 17 & 21,8 \\
\hline & Violoncelo & 11 & 14,1 \\
\hline \multirow{9}{*}{$\begin{array}{l}\text { PERCUSSÃO (IDIOFONES DE } \\
\text { ALTURA INDEFINIDA) }\end{array}$} & Instrumentos & Quantidade & Percentual \\
\hline & Pandeiro & 45 & 57,7 \\
\hline & Caixa & 45 & 57,7 \\
\hline & Zabumba & 42 & 53,8 \\
\hline & Ganzá & 22 & 28,2 \\
\hline & Tambor de Maracatu & 16 & 20,5 \\
\hline & Agogô & 13 & 16,6 \\
\hline & Pratos & 13 & 16,6 \\
\hline & Triângulo & 11 & 14,1 \\
\hline \multirow{5}{*}{ MADEIRAS (AEROFONES) } & Instrumentos & Quantidade & Percentual \\
\hline & Flauta / Flautim & 49 & 62,8 \\
\hline & Acordeom & 48 & 61,5 \\
\hline & Sax & 34 & 43,6 \\
\hline & Clarineta & 22 & 28,2 \\
\hline
\end{tabular}

Apêndice F - Percentual dos instrumentos presentes na discografia de Antonio Carlos Nóbrega 


\section{Posfácio}

\section{o Carrossel do Destino}

Estou diante de uma difícil, quase impossível tarefa.Daquelas, para as quais, como se diz hoje em dia, "não tem boquinha". Eu caço terra nos pés e não acho; mas o mandante acha que eu acho! E agora?! Seja o que Deus e ele quiserem.

Pois não é que o autor deste extraordinário trabalho veio solicitar "uma avaliação", "uma análise", uma "crítica" deste conteúdo. E para me complicar, quer "por escrito", dando a entender que, em caso de incompetência, estarei nas barras dos tribunais. 0 pedido-ordem deixa-me na maior das liberdades: decifra-me ou devoro-te.

De fato, muito me agradam estes conteúdos bem como a forma de abordá-los. Desde os tempos da escolha do tema que venho dando meus pitacos. Quando da defesa, eu disse logo: tem de publicar! Parece que eu estava inspirado, porquanto o presente trabalho traz um denso conteúdo, embalado numa excelente apresentação, o que transforma este livro - juro, leitor! -, numa mensagem, num apelo.

Saber disso eu sei; gostar das coisas aqui contidas e contadas, eu gosto; entretanto, meter-me a crítico são outros quinhentos. Estou dizendo o mesmo que disse o pobre matuto, humilde, ajoelhado, com o chapéu de palha na mão, para o Frei Damião que, de cara dura, lhe mandava fazer o pelo-sinal. 
- Meu padim, saber as palavra é fáci! Só não sei é espaiá na cara!

O figurino exige; eu é que não vou conseguir ser um bom alfaiate.

Costurar logo para Luís?! Respeita Januário, moleque!

$$
* * *
$$

Deixem-me dizer quem, no meu modo de entender, é Luís Adriano:

Luís é desses filhos

Qu'a gente tem, sem ter feito;

Presente à nossa retina,

Se hospeda no nosso peito!

Ainda que, não de sangue,

É filho do mesmo jeito!!!

Artilheiro do meu time! Certeza do meu campeonato; isto na teoria, porque lá de onde a gente veio, ele vítima do destino, é rubro-negro; e eu, pela sorte, sou tricolor!

Oriundo do agreste meridional de Pernambuco, por onde certa vez, passou o diabo e viu alguns "neguim". Naquele tempo, não havia a lei que proíbe chamar os neguim de neguim.

Gostou deles. Virou-se para o secretário e ordenou: "agarra uns"! Aqui, segundo as más línguas, está o étimo de Garanhuns, aquela terra bendita, país do frio e de Lula Mendes Costa.

Até hoje se diz que quando o diabo não vem, manda aqueles diabim!... 
É difícil, muito difícil encontrar as "teses" de mestrado e doutorado agradando até mesmo aos seus próprios autores. O formalismo, as "orientações" que truncam a liberdade criativa etc etc terminam por abortar os conteúdos; não agradam nem aos que as elaboram. Aqui e ali, ouve-se o pós-graduando exclamar: "esse trabalho não me agrada." Na verdade, o que eles renegam é lembrar do quanto penaram com aquele trabalho forçado.

Creio que isto também pode mostrar que o programa de PósGraduação brasileiro tem dinheiro, mas não tem planejamento e, não tendo este último, é desprovido de controle! o Governo tem sido bom! De Lula, outro made in Garanhuns, a quem dou a mão à palmatória, também para este setor eu não esperava nada, ou quase. Pois bem, em relação a outras administrações, foi mudança da água para o vinho!

Na prática, porém, o que se tem visto é que os docentes "saem" e, hoje em dia, já nem precisam de "sair" para enfrentar um programa de P.G. Tudo bem, mas falando sério, além das titulações, qual tem sido o resultado desta novidade na vida departamental? Claro que as exceções já nascem salvas!

Não seria tempo de dizer aos professores algo assim: os departamentos e, com eles a realidade local, regional estão precisando de pesquisas aplicáveis neste e naquele aspectos. As universidades precisam fazer ciência.

Daí, talvez, surgissem trabalhos do tipo apresentado por Luís Adriano: nascido da realidade sócio-cultural e para ela dirigido.

Aqui, a conversa é outra. Aparece de cabo a rabo uma reflexão criativa, desprovida de parti pris e de qualquer preconceito ou concessão. Esta síntese representa o resultado de um extraordinário poder de contemplação e de criação. 
Na sua competência, Lula não vem propor algo já conhecido, travestido em outras palavras. Este texto, apesar de originalmente marcado pelo formalismo exigido na dissertação acadêmica, não foi equacionado como dever de casa... ou de fim de curso. Não se reduz ao simples passaporte para aquisição de um diploma.

Nesta produção intelectual, percebe-se uma fluência e confluência de idéias, como bem manda o rigor do método e a fidelidade ao rosto do real. Neste texto, se constata, de imediato, um conhecimento de causa.

\section{$* * *$}

Eu morro e não aprendo. Já dei fé que vou ficar sem conseguir saber direito e com exatidão (será que se pode?) o que é "armorial". Sei que esta minha posição estanque, em nada diminui o movimento, como também não vai importunar aqueles que o criaram e o conservam.

Não devo ficar entristecido; vou creditar aos caprichos do destino de jamais alcançar a definição (será que deve ser um artigo definido como qualquer mercadoria?!) de armorial.

Após a leitura desta proposta de Luís, é bom que também o diga, aprendi a identificar vários pontos positivos constantes do movimento: determinação pela volta aos princípios; busca das origens e fidelidade a elas; preservação da originalidade e integração das criações, sejam estas de cunho mais "popular" ou mais "erudito", ou estas duas variáveis integradas; o cultivo dos emblemas e até o prazer de se posicionar diante do emblemático. Luís Adriano nos propõe um harmonioso esforço intelectual, visando localizar tudo isto na temática poética de Antonio Nóbrega. Neste artista, Luís, músico que é, identifica até mesmo o timbre da voz empostada, uma espécie de sotaque, herança dos cantadores populares. 
Quer saber duma coisa? Vou atirar no pouco que consigo perceber, tentando alcançar o que não vejo.

Embora não sabendo o que venha (virá?) a ser este tal de toque armorial presente nas produções artísticas, não hesito em sustentar minha intuição: Luís Adriano é armorial!!! É o seu trabalho que não me deixa mentir!

O leitor vai perceber que progredir nestes capítulos é o mesmo que estar vendo Nóbrega em cena; quem ainda não o viu, corre o risco de estar perdendo fenômenos como Tonheta, o Rei e o Palhaço, etc etc etc. Este trabalho é útil para se compreender cenas do seu e do nosso mundo "brincante".

Como se chegar a Nóbrega e a tantos outros artistas eruditos, porém plugados na alma popular? Nas páginas a seguir o leitor encontrará um atualizado mapa deste destino. Deixar de ler esta insinuação é o mesmo que cair do cavalinho; é perder as evoluções do carrossel; é ficar sem saber dos mistérios e dos encantamentos de Reis e Palhaços das mais diferentes esferas.

Faço minhas as palavras do filósofo e jornalista Astier Basílio: "ver Nóbrega em cena (ou neste trabalho, direi eu), é perceber o refinamento de todo um manancial de referências de ritmos e culturas".

Concluindo:

$1^{\circ}$. Tenho de repetir: garanto ao leitor que ele não vai encontrar nestas páginas o resultado de uma destas pesquisas feitas a muque e ao acaso, dessas tantas elaboradas sem graça, apenas para se pagar uma obrigação, ou mesmo para se ter acesso a uma bolsa. A espontaneidade do dizer leva à conclusão de que 
este texto pode até ainda continuar com jeito de tese, mas não é uma prova; não é tampouco uma provação acompanhada dos seus vexames;

$2^{\circ}$. Mais do que tudo isto, o que aparece é uma PROVOCAÇÃO; é um grito que brota da realidade nordestino-brasileira.

Poder-se-ia dizer, até, que se trata de um grito ético, porque justamente saído da boca do povo que, há tempo e desde os começos, pede para se ver escutado e acompanhado nas suas evoluções!

Através de Nóbrega, o dançarino-professor, e do mestre Luís, o artista tocador e jornalista, é gostoso de se ouvir o cantar cadenciado do povo.

Isto é o que tenho a dizer, salvo melhor (pré)juízo; não trago um trabalho de crítica literária; paciência! Mas eu não mudo de opinião! E de Salgueiro a Bodocongó, de Garanhuns a Campina, no mundo inteiro, só se ouve o povo dizer ao povo:

RESPEITA LUÍs, GENTE!!!!!!!!

Parabéns.

Severino Gomes de Sousa Filho (Biu). Em C. Grande, julho de 2011. 




\section{LIVROS EDUEPB E LATUS}

1. Pluralismo Jurídico: Para além da visão monista - Raíssa de Lima e Melo

2. Mulher, corpo e cuidado - Maria de F. de A. Silveira; e Dulce M. Rosa Gualda

3. Avaliação de serviços: um olhar na qualidade da gestão (Orgs) Maria José Cariri Benígna; e Maria A. Amado Rivera

4. Farmacêutico na Farmácia - Rosimary S. Cunha Lima; Maria do Carmo Eutálio; e Magnólia de L. S. Targino

5. Representações sociais e saúde - Aliana Fenandes; Maria. do $R$ de Carvalho; e Moisés Domingos Sobrinho

6. EPI Info para iniciantes - (Orgs) Sonia Maria de L. Maciel; e Pedro Henrique de A. e S. Leite

7. Ensino de lingua: do impresso ao virtual - (Orgs) Antonio de Pádua Dias da Silva; Maria de L. L. Almeida; Simone Dália de Gusmão Aranha; e Tereza. N. de Farias Campina

8. A história da mídia regional - C. B de Souza; F. G. de Oliveira; e Gorete M. Sampaio de Freitas

9. Livro de resumo de monografias - Maria Dora Ruiz Temoche

10. Planejamento tributário no campo de incidência do ICMS Alexandre H. S. Ferreira; e Ana Maria da P. Duarte

11. 1930 - A Revolução que mudou a História do Brasil - (Orgs) João M. L. Santos; Cláudo José L. Rodrigues; Inês Caminha L. Rodrigues; e José Octávio de A. Melo

12. Curso de Direito Constitucional - Lorivaldo da Conceição

13. Fragmentos - Juarez Filgueras de Góis

14. Gênero em questão - (Org) Antonio de Pádua Dias da Silva

15. Jogos eletrônicos - Eliane de M. Silva; Filomena M. G. da S. C Moita; e Robson Pequeno de Souza

16. Nascido do Fogo, Filho da Paz - Ket Jeffson Vasconcelos Leitão

17. Política Tributária e Justiça Social - Alexandre Henrique Salema Ferreira

18. Revista Sócio-Poética - Departamento de Letras da UEPB

19. O Sábio e a Floresta - Moacir Werneck de Castro

20. Universidade e o fazer poético em prosa e poesia - (Orgs) 
Fabíola Nóbrega; Marcelle V. Carvalho; e Tatiana Fernandes Sant'ana

21. Sustentabilidade - um enfoque sistêmico - (Orgs) Waleska S. Lira; Helio de L. Lira; Maria José dos Santos; e Lincon Eloy de Araújo

22. Bioquímica clínica - uma abordagem geral - Sandra Reis Farias

23. Mortalidade Geral - Epidemologia - Anthonyanny A. Silva Lima; Maria J. Cariri Benigna

24. Estudos Filológicos: Literatura - Cultura - Marinalva Freire da Silva

25. Dicionário de termos relativos a gestão de pessoas - Maria Dora Ruiz Temoche

26. Práticas de Políticas Públicas - (Orgs) Marcelo A. Pereira; Maria da G. A. Pereira; Sandra. M. A de S. Celestino; Sueli Ramos de R. M. Cavalcanti; e Wíliam A. de Lacerda

27. Saúde Humana - (Org) Inácia Sátiro Xavier de França

28. O Segredo de Pergamo - Ket Jeffson Vasconcelos Leitão

29. A queda do meteorito - Giusone Ferreira Rodrigues

30. Trajetória empreendedora: estudo de casos numa realidade local e global - (Org) Vera Lúcia Barreto Motta

31. Identidades de gênero e práticas discursivas - (Org) Antonio de Pádua Dias da Silva

32. O lugar da Educação Física - Maria José de Figueirêdo Gomes

33. O papel político dos fóruns de educação de jovens e adultos - Eduardo Jorge Lopes da Silva

34. Pesquisa histórica - resumo de monografias - (Orgs) Luíra Freire Monteiro; e Flávio Carreiro de Santana

35. Anos de luta - Waldir Porfírio

36. Mulher e violência: histórias do corpo negado - Lígia Pereira dos Santos

37. Agricultura orgânica - José Geraldo R. dos Santos; e Emmanuelly Calina X. R. Santos

38. Sobre o diálogo: introdução a uma leitura filosófica de Julio Cesar Kestering

39. Novos cenários da Administração - (Org) maria Dora Ruiz Temoche

40. 0 despertar da cultura - (Org) Marinalva Freire da Silva 
41. Manual básico de Radiologia Odontológica - Maria de Fátima Cavalcanti Rodrigues

42. Formas de sociabilidade e instauração da alteridade - Inácia S. Xavier de França; Lorita M. Freitag Paghuca

43. Paremiologia nordestina - Fontes Ibiapina

44. Resistência indígena no Piauí colonial 1718 - 1774 - João Renor F. de Carvalho

45. Planejando o (des)envolvimento local - Roberto Alves de Araújo; e Ana Siqueira de Araújo

46. Deuses em poéticas: estudos de Literatura e Teologia (Orgs) Salma Farraz; Antonio Magalhães; Eli Brandão; Waldecy Tenório; Douglas Conceição

47. Campina Grande em debate - (Org) Roberto Véras de Oliveira

48. História do Direito e da violência: recortes de uma abordagem interdisciplinar - Marcelo Alves Pereira Eufrásio

49. Contos jurídicos: normas de sobredireito da Lei de Introdução ao Código Civil - Ket Jeffson Vasconcelos Leitão

50. A Bacia do Rio Gramame: Biodiversidade, uso e conservação - (Orgs) José Etam de Lucena Barbosa; e Takako Watanabe; e R. José da Paz

51. Ser criança - repensando o lugar da criança na educação infantil - (Orgs) Glória M. de Souza Melo; Soraya. M. de A. Brandão; e Marinalva. da Silva Mota

52. Estudos Sociais da Ciência e Tecnologia - (Org) Renato Dagnino

53. De portas abertas para o lazer - (Orgs) Elaine Melo de B. Costa Lemos; Eduardo Ribeiro Dantas; e Cheng Hzin Nery Chão

54. Gênero e práticas culturais - (Orgs) Charliton J. dos Santos Machado; Idalina M. F. Lima Santiago; e Maria L. da Silva Nunes

55. Da resistência ao poder - o (P)MDB na Paraíba (1965 / 1999) - José Otávio de Arruda Mello

56. Políticas públicas e desenvolvimento regional - (Orgs) Carlos. A. Máximo Pimenta; Cecília Pescatore Alves

57. Histórias vividas e contadas no Bar do Brito - (Orgs) A. C. Barbosa de Souza; Antonio Guedes Rangel Junior; Clara M. Araújo Pinto; e Sonia Maria A. de Oliveira Brito

58. De memória e de identidade - (Orgs) Antonia M. M. da Slva; Francisco Paulo da Silva; Ivanaldo Oliveira dos Santos; e Maria Edileuza da Costa 
59. A luz que não se apaga - Rômulo de Araújo Lima

60. Cálculo avançado - (Orgs) Aldo Trajano Louredo; e Alexandro M. de Oliveira; e Osmundo Alves Lima

61. Fisioterapia na gravidez - (Org) Maria do Socorro B. e Silva

62. Educação Universitária - Pedro Bergamo

63. Amora - Fidélia Cassandra

64. Educação em questão - recortando temas e tecendo ideias - (Pedro Lúcio Barboza)

65. Ciço de Luzia - Efigênio Moura

66. Zila Mamede - trajetórias literárias e educativas - Charliton José dos Santos Machado

67. A voz da infância e outras vozes - Calos Azevedo

68. A Educação da Mulher em Lima Barreto - (Jomar Ricardo da Silva)

69. Porta aberta à poesia popular - Almira Araújo Cruz Soares

70. Mulheres representadas na literatura de autoria feminina Antonio de Pádua Dias da Silva

71. Residências terapêuticas - (Orgs) Maria de Fátima de A. Silveira e Hudson Pires de O. Santos Júnior

72. A nuvem de hoje - Braulio Taveres

73. Tecnologias digitais na educação - (Orgs) Robson Pequeno de Sousa; Filomena M. C. da S. C. Moita; e Ana Beatriz Gomes Carvalho.

74. A representação da sogra na obra de Leandro Gomes de Barros - José Itamar Sales da Silva

75. Viagem aos 80 anos da Revolta de Princesa - Janduí Dantas

76. Cidadania glocal, identidade nordestina - José Marques de Melo

77. Uma nova ciência para um novo senso comum - Marcelo Germano Gomes

78. A feira - o trovador encantado - Maria de Lourdes Nunes Ramalho

79. Nordeste como inventiva simbólica - Geralda Medeiros Nóbrega

80. Era uma vez diferente - Aline Pereira

81. Colecionismo, práticas de campo e representações - Maria Margaret Lopes e Alda Heizer. 


\section{Sobre o livro}

Impressão Gráfica Universitária da UEPB Formato $15 \times 21 \mathrm{~cm}$.

Mancha Gráfica $10,5 \times 16 \mathrm{~cm}$.

Tipologias Gentium Basic 11,5/14 pt

Miolo Papel Apergaminhado $75 \mathrm{~g} / \mathrm{m}^{2}$

Capa Cartão Supremo 250g/m² 
